\title{
String Matching and Online Retention Time Prediction for Real-Time Information-Driven Mass Spectrometry
}

\author{
By \\ Robert James Peace
}

A thesis submitted to the Faculty of Graduate and Postdoctoral Affairs in partial fulfillment of the requirements for the degree of

\section{Masters of Applied Science \\ in Biomedical Engineering}

Ottawa-Carleton Institute for Biomedical Engineering

Department of Systems and Computer Engineering

Carleton University

Ottawa, Ontario, Canada

September 2011 
Library and Archives

Canada

Published Heritage Branch

395 Wellington Street Ottawa ON K1A ON4 Canada
Bibliothèque et

Archives Canada

Direction du

Patrimoine de l'édition

395 , rue Wellington

Ottawa ON K1A ON4

Canada
Yourfile Votre référence

ISBN: 978-0-494-83047-5

Our file Notre référence

ISBN: 978-0-494-83047-5
NOTICE:

The author has granted a nonexclusive license allowing Library and Archives Canada to reproduce, publish, archive, preserve, conserve, communicate to the public by telecommunication or on the Internet, loan, distribute and sell theses worldwide, for commercial or noncommercial purposes, in microform, paper, electronic and/or any other formats.

The author retains copyright ownership and moral rights in this thesis. Neither the thesis nor substantial extracts from it may be printed or otherwise reproduced without the author's permission.
AVIS:

L'auteur a accordé une licence non exclusive permettant à la Bibliothèque et Archives Canada de reproduire, publier, archiver, sauvegarder, conserver, transmettre au public par télécommunication ou par l'Internet, prêter, distribuer et vendre des thèses partout dans le monde, à des fins commerciales ou autres, sur support microforme, papier, électronique et/ou autres formats.

L'auteur conserve la propriété du droit d'auteur et des droits moraux qui protège cette thèse. $\mathrm{Ni}$ la thèse ni des extraits substantiels de celle-ci ne doivent être imprimés ou autrement reproduits sans son autorisation.
In compliance with the Canadian Privacy Act some supporting forms may have been removed from this thesis.

While these forms may be included in the document page count, their removal does not represent any loss of content from the thesis.
Conformément à la loi canadienne sur la protection de la vie privée, quelques formulaires secondaires ont été enlevés de cette thèse.

Bien que ces formulaires aient inclus dans la pagination, il n'y aura aucun contenu manquant. 


\section{String Matching and Online Retention Time Prediction for Real-Time Information-Driven Mass Spectrometry}

Submitted by Robert James Peace

in partial fulfillment of the requirements for

the degree of Master of Applied Science in Biomedical Engineering

Thesis Supervisor
Dr. James R Green

Chair, Department of Systems and Computer Engineering Dr. Howard Schwartz

2011, Carleton University 


\section{Abstract}

Tandem mass spectrometry (MS/MS) is a powerful analytical technique which is the current state of the art with respect to protein identification. MS/MS experiments are characterized by the generation of abundant spectral data; as a result, mass spectrometry data analysis techniques are extremely important for the correct identification of proteins. Analysis of MS/MS data is ultimately limited, however, by MS/MS data acquisition. Currently, most MS/MS data collection is performed in a naive abundance driven fashion which does not make optimal use of experimental hardware. Information-driven tandem mass spectrometry (idMS/MS) techniques seek to couple data analysis and data acquisition with the goal of guiding data acquisition in order to increase hardware efficiency and consequently the quality and quantity of protein identifications in an experiment. idMS/MS presents several challenges, primarily a real-time deadline on data analysis which is imposed by the mass spectrometry hardware. Commodity parallel hardware such as GPGPU and Cell B/E show promise for meeting the real-time requirements of idMS/MS. A computationally intensive step in the MS/MS data analysis pipeline - searching peptide sequence tag data over large proteomic or genomic databases - has been parallelized using these platforms in order to explore the platforms' suitability for idMS/MS. Results of these experiments are extremely promising, with a highly tailored searching algorithm producing throughputs of $2066.4 \mathrm{Gbit} / \mathrm{s}$ on a NVIDIA GeForce GTX 570 graphics card, 943.8 Gbit/s on a NVIDIA GeForce GTX 260 graphics card and $219.3 \mathrm{Gbit} / \mathrm{s}$ on a QS22 Cell blade server. These experiments represent typical peptide sequence tag search conditions. During idMS/MS data analysis, the idMS/MS system must also be aware of the experiment's current retention time. This presents a second challenge for the creation of an idMS/MS system. Currently, mapping of retention time to elution time is restricted to linear models which are a function of the conditions of the 
experiment, and which require careful calibration of the instrument and precise knowledge of the LC gradient. We have leveraged our real-time access to spectral data in order to develop a novel probabilistic approach which maps currently observed survey ion spectrum data to a predicted retention time map of the experiment. Using this method, we have predicted the retention time during the elution of 9 confidently identified peptides during a MS/MS experiment with a mean squared error of 0.00627 relative to the retention time values of these peptides, using only data available to the mass spectrometer during the experiment, and without the requirement of prior knowledge of the instrument. This approach does not require characterization of the LC gradient, therefore the need for a parameterized linear gradient is removed. Additionally, as a step toward the creation of the retention time / experiment time mapping algorithm, we have developed a novel ANN network which has predicted the retention time of 1917 peptides with a $\mathrm{R}^{2}$ value of 0.9483 using only 23 inputs and 10 internal nodes. 


\section{Acknowledgements}

I would like to thank James Green, Jeff Smith, Frank Dehne, Catalin Patulea, Travis Stewart, Hanan Mahmoud, Douglas Peace, Christine Peace, Derek Peace, Charlene Peace, Emilio Franco, Richard Monette and Dave Mandia

This study was supported by the Natural Sciences and Engineering Research Council of Canada. 


\section{Table of Contents}

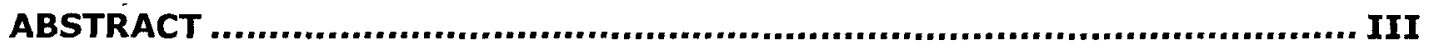

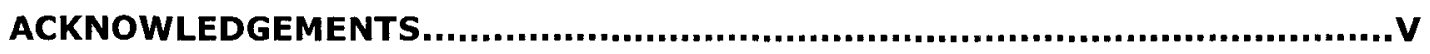

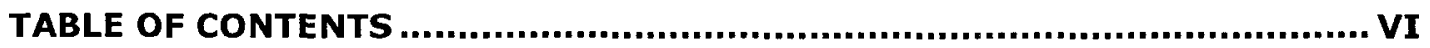

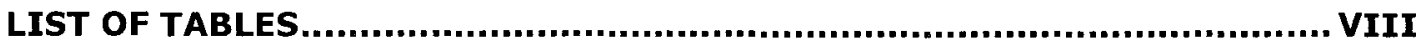

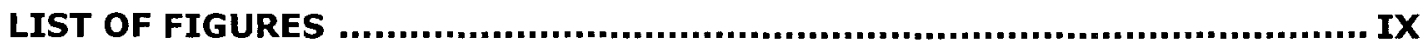

LIST OF ABBREVIATIONS ............................................................... XI

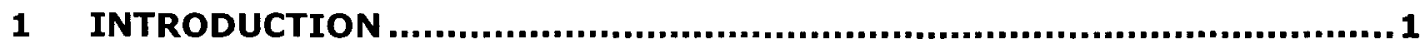

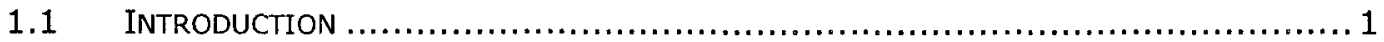

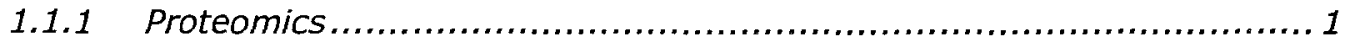

1.1.2 Mass Spectrometry ..................................................... 2

1.1.3 Tandem Mass Spectrometry ............................................. 4

1.1.4 Liquid Chromatography and Retention Time ................................... 7

1.1.5 Commodity Parallel Hardware Architectures ................................... 10

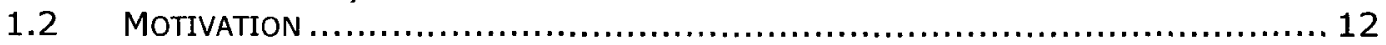

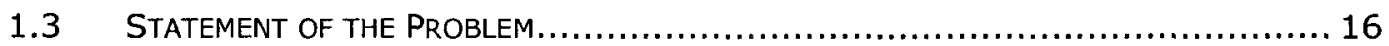

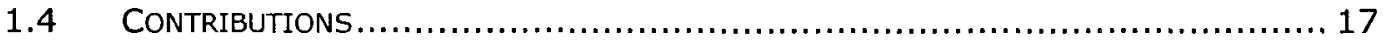

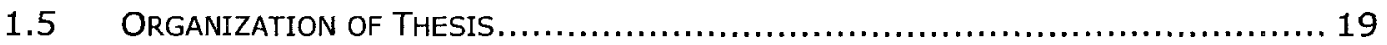

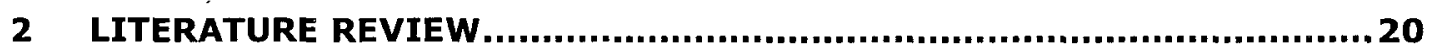

2.1 Computational METHOdS for MASS SPECTROMETRY ................................ 20

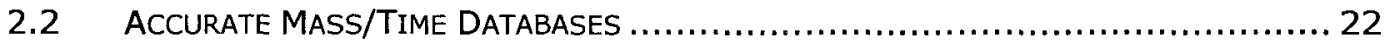

2.3 RETENTION TIME PREDICTION ........................................................ 24

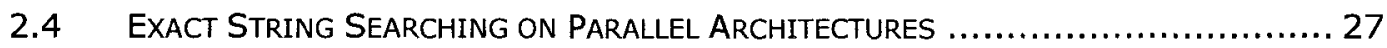

3 EXACT STRING MATCHING FOR MS/MS PROTEIN IDENTIFICATION USING THE CELL BROADBAND ENGINE................................................30

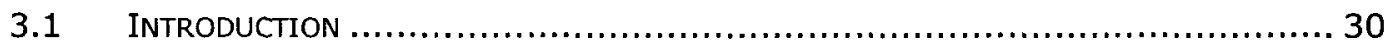

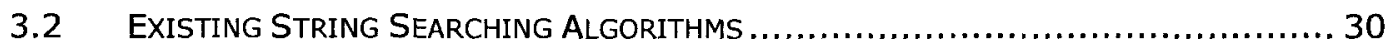

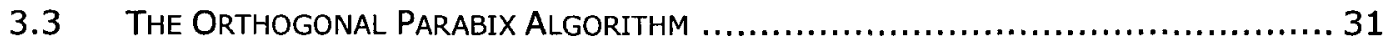

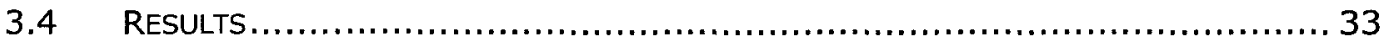

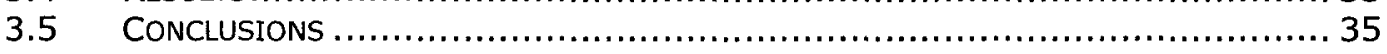

4 SIX-FRAME GENOMIC STRING MATCHING FOR PEPTIDE SEQUENCE TAGS USING THE CUDA PLATFORM.................................................................. 37

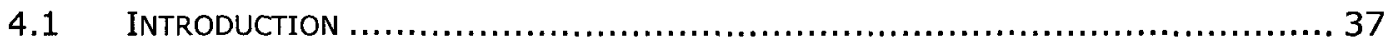

4.2 AdAPTING ORTHOGONAL PARABIX TO GENOMIC DATABASES $\ldots \ldots \ldots \ldots \ldots \ldots \ldots \ldots \ldots \ldots$

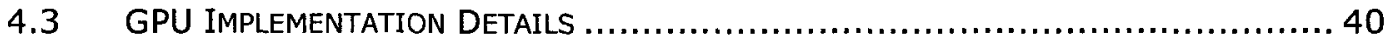

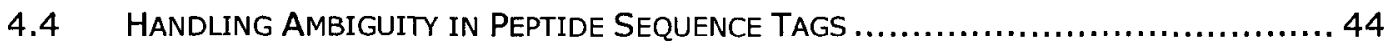

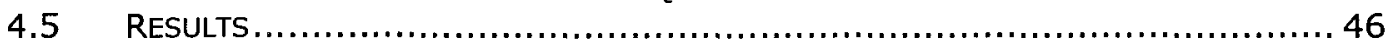

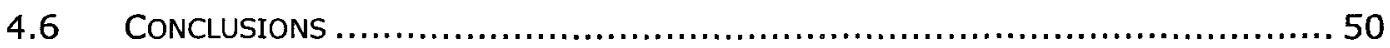

5 ON-LINE RETENTION TIME / EXPERIMENT TIME MAPPING FOR EXPERIMENTAL MASS SPECTROMETRY DATA .........................................51

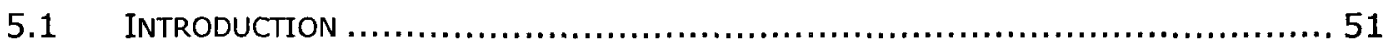


5.2 OVERView of ONLine Retention Time / EXPERIMENT Time MaPPing Module ........ 52

5.3 PEPTIDE RETENTION TIME PREDICTION ............................................. 54

5.3.1 Choosing a Linear Regression Technique for Retention Time Prediction 54

5.3.2 Implementation of existing ANN models.................................... 55

5.3.3 Producing a novel ANN architecture........................................ 55

5.4 THE RETENTION TIME / EXPERIMENT TIME MAPPING ALGORITHM....................60

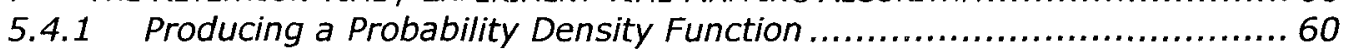

5.4.2 Finding the Global Maximum of the Support Function .....................6 64

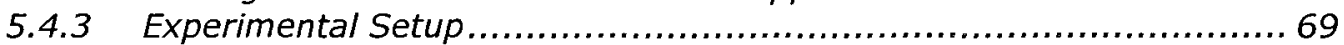

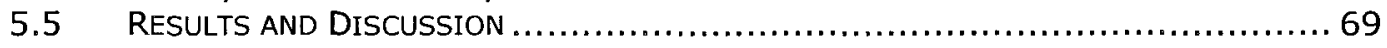

5.5.1 ANN Retention Time Estimation Model Accuracy..........................69 69

5.5.2 Retention Time / Experiment time Mapping Accuracy..................... 71

6 THESIS SUMMARY AND FUTURE RECOMMENDATIONS .......................75

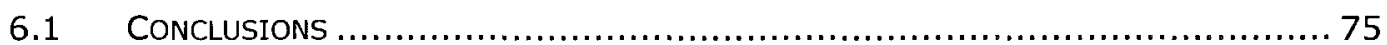

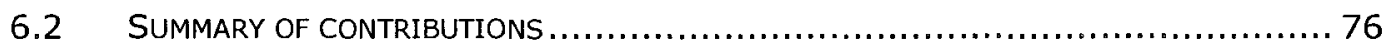

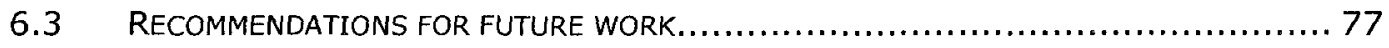

REFERENCES.................................................................................... 79 


\section{List of Tables}

TABLE 5-1 - TEST MSE VALUES FOR ANN INPUT CONFIGURATIONS CONSIDERED DURING

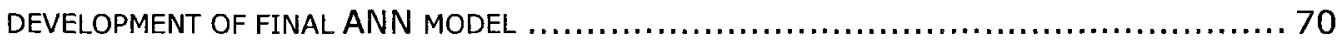

TABLE 5-2 - TEST RESULTS FOR THE NAIVE SCANNING METHOD FOR RETENTION TIME / EXPERIMENT

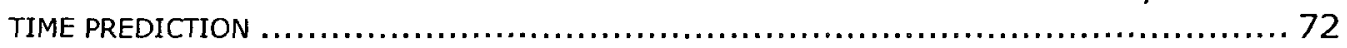

TABLE 5-3 - TEST RESULTS FOR THE GOLDEN SECTION SEARCH METHOD FOR RETENTION TIME /

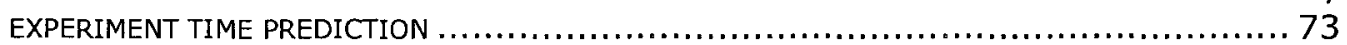

TABLE 5-4 - TEST RESULTS FOR THE GRADIENT ASCENT SEARCH METHOD FOR RETENTION TIME /

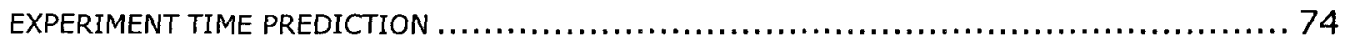




\section{List of Figures}

FIGURE $1-1-$ A M/Z SPECTRUM RESULTING FROM MASS SPECTROMETRY $\ldots \ldots \ldots \ldots \ldots \ldots \ldots \ldots . \ldots \ldots$

FIGURE 1-2 - MAJOR STEPS IN THE MS/MS PIPELINE. DATA IS COLOUR-CODED BY PEPTIDE; ALL FOUR PEPIIDES APPEAR IN THE SURVEY ION SCAN, WHILE THE PRODUCT ION SCAN IS LIMITED TO

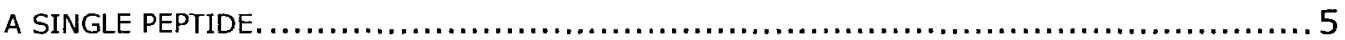

FIGURE 1-3 - DE NOVO SEQUENCING PRODUCING LVLY FROM A PRODUCT ION SPECTRUM ..........6

FiguRE 1-4 - OVERVIEW OF THE LC-MS/MS PIPELINE. PEPTIDES TRAVEL FROM THE LIQUID CHROMATOGRAPHY PHASE TO THE MASS SPECTROMETER, WHERE THEY ARE IONIZED AND THEN DETECTED BASED ON THEIR MASS/CHARGE RATIO. DURING A PRODUCT ION SCAN, PEPTIDES PASS THROUGH A COLLISION CHAMBER BETWEEN IONIZATION AND DETECTION. ............... 8

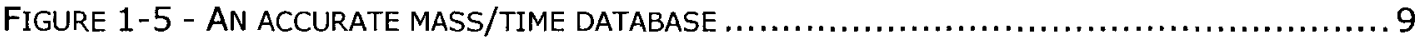

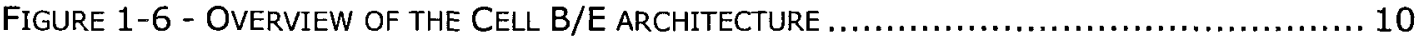

Figure 1-8 - ABUNDANCE-DRIVEN MS/MS PIPELINE. PRODUCT ION SCANS ARE REPEATED ON HIGH-ABUNDANCE PEPTIDES FOR THE ENTIRETY OF THE EXPERIMENT . ...................... 13

FIGURE 1-9 - INFORMATION-DRIVEN MS/MS PIPELINE. HARDWARE PRODUCTS ARE HIGHLIGHTED IN RED, WHILE IDMS/MS PRODUCTS ARE HIGHUGHTED IN BLUE............................ 15

FIGURE 3-1 - ORTHOGONAL ENCODING OF A DATABASE SEGMENT INTO BITSTREAMS A, D, AND F. RED ARROWS INDICATE THE ENCODING OF "A" AMINO ACIDS BY THE FIRST "A" BITSTREAM.. 32

FIGURE 3-2 - ONLINE SHIFT-AND PROCEDURE FOR QUERY "ARND" IN DATABASE CONTAINING "...QWVARNDA...". BITSTREAMS A, R, N AND D ARE FETCHED INTO MEMORY IN THE ORDER THAT THEY APPEAR IN THE QUERY.

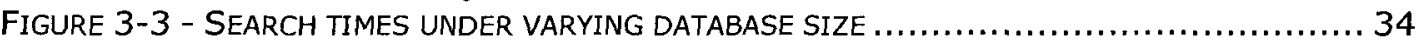

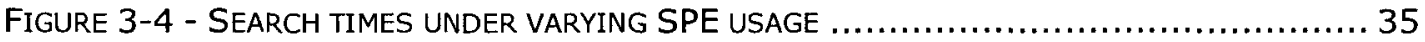

FIGURE 4-1 - CONVERTING A GENOMIC DATABASE INTO A PROTEOMIC DATABASE ................. 38

FIGURE 4-2 - CUDA MEMORY HIERARCHY. PERFORMANCE IS OPTIMAL WHEN ALL DATA IS STORED IN GPU GLOBAL MEMORY AND THE TRADITIONAL MEMORY PIPELINE IS USED. $\ldots \ldots \ldots \ldots \ldots \ldots \ldots 41$

FIGURE 4-3 - MODIFICATION TO SHIFT AND AND PROCEDURE FOR HANDLING BYTE-ADDRESSABLE MEMORY ON GPU

FIGURE 4-4 - COMPARISON OF RELATIVE TIME SPENT ON COMPUTE VS. MEMORY OPERATIONS BEFORE AND AFTER OPTIMIZATION OF MEMORY TRANSFERS. GREEN BARS REPRESENT POSTOPTIMIZATION NUMBERS. "SEARCH" REPRESENTS COMPUTATION TIME, WHILE "MEMCPYHTOD" AND MEMCPYDTOH" REPRESENT TIME SPENT ON MEMORY TRANSFERS BETWEEN HOST AND

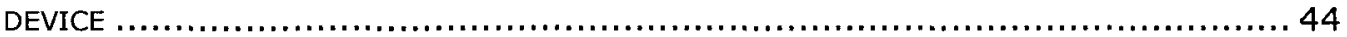

FIGURE 4-5 - EFFECT OF QUERY SIZE ON SEARCH TIMES ON GPUS. SERIAL SEARCH TIMES ARE NOT PRESENT IN ORDER TO HIGHLIGHT THE COMPARISON BETWEEN GPU DATA POINTS........... 48

FIGURE 4-6 - EFFECT OF AMBIGUOUS QUERIES ON SEARCH TIMES. EXPERIMENT PERFORMED ON GTX 570 GRAPHICS CARD . ............................................................... 48

FIGURE 4-7 - COMPARISON OF GPU AND CPU SEARCH TIMES OVER VARYING DATABASE SIZES. .. 49

FIGURE 5-1 - PROCESS FLOW DIAGRAM SURROUNDING THE RETENTION TIME / EXPERIMENT TIME

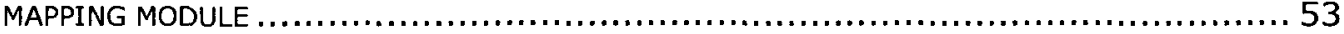

FIGURE 5-2 - TEST SET MSE FOR VARYING NUMBERS OF HIDDEN NODES IN ANN ARCHITECTURE. MSE IS OPTIMAL FOR 14 HIDDEN NODES, HOWEVER THERE IS NO CLEAR DOWNWARD TREND PAST 10 NODES. ................................................................. 59

FIGURE 5-3 - TEST SET MSE OVER VARYING TRAINING LENGTHS. TRAINING BEYOND 900 EPOCHS

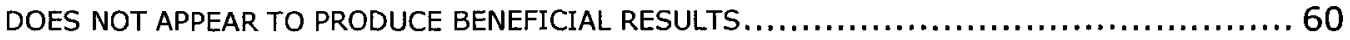

FIGURE 5-4 - CREATION OF KERNEL FUNCTION FROM 2D AMT DATABASE. A PEPTIDE MASS $M$, REPRESENTED BY THE BLUE LINE, WAS OBSERVED IN THE MASS SPECTROMETER. THE RESULTING PROBABILITY FUNCTION IS THE RESULT OF KERNEL FUNCTIONS CENTERED AROUND THE THREE AMT DATABASE POINTS WHICH HAVE A MASS CLOSE TO M..............................6 61

FIGURE 5-5 - GOLDEN SECTION SEARCH RANGES (PICTURED AS VERTICAL LINES) RELATING TO THE SUM OF TWO GAUSSIAN CURVES OF EQUAL MAGNITUDE. THE SUPPORT FUNCTION, IN BLUE, 
WOULD BE SEEN AS UNIMODAL BY THE GOLDEN SECTION SEARCH ALGORITHM FOR EACH OF THE TWO SECTIONS OF INTEREST. ........................................................ 66

FigURE 5-6 - GOLDEN SECTION SEARCH OVER GAUSSIANS OF DIFFERENT AMPLITUDES. THE LEFT REGION IS CLEARLY POLYMODAL, AND THE GOLDEN SECTION SEARCH MAY FAIL IN THIS REGION, HOWEVER THE RIGHT SECTION CONTAINS THE GLOBAL MAXIMUM AND THE GOLDEN SECTION SEARCH WILL SUCCEED IN THIS REGION. BOUNDARIES FOR THE SEARCH ARE MARKED WITH VERTICAL LINES, AND THE SUPPORT FUNCTION IS DRAWN IN BLUE......................6 67 FIGURE 5-7 - PLOT OF PREDICTED RETENTION TIME OF ANN MODEL VS. ACTUAL RETENTION TIME 71 


\section{List of Abbreviations}

\begin{tabular}{|l|l|}
\hline MS & Mass Spectrometry \\
\hline MS/MS & Tandem mass spectrometry \\
\hline LC-MS/MS & Liquid chromatography tandem mass spectrometry \\
\hline idMS/MS & Information-driven mass spectrometry \\
\hline Cell B/E & Cell Broadband Engine \\
\hline GPGPU & General purpose programming on graphics processing units \\
\hline API & Application programming interface \\
\hline NET & Normalized elution time \\
\hline AMT & Accurate mass and time \\
\hline ANN & Artificial neural network \\
\hline SVM & Support vector machine \\
\hline SVR & Support vector regression \\
\hline QSRR & Quantitive structure-retention relationship \\
\hline MSE & Mean squared error \\
\hline
\end{tabular}




\section{Introduction}

\subsection{Introduction}

This section provides relevant background information on the topics of mass spectrometry, including tandem mass spectrometry and liquid chromatography mass spectrometry, commodity parallel hardware, and string matching.

\subsubsection{Proteomics}

Proteomics is the study of the structure and function of proteins. A protein is a biochemical compound consisting of any number of amino acids connected via peptide bonds into a chain-like structure. Amino acids are molecules which contain an amine group, a carboxylic acid group, and a side chain; there are 20 distinct side chains, each of which corresponds to one of 20 possible amino acids. Proteins are produced in the cell nucleus through the process of transcription and translation, which generates amino acid chains from DNA sequences based on the genetic code.

Once a protein has been produced through transcription and translation, it folds into a complex three-dimensional structure which, in turn, largely determines the function of the protein. This structure is not relevant to this thesis, however. Only the primary structure of the protein - the amino acids present and the order in which they appear - will be examined. Thus, for our purposes, proteins can be encoded as character strings with each character representing an amino acid. For example, a protein that consists of the amino acids Alanine (A), Arginine (R), Asparagine (N), and Aspartic Acid (D) in that order is represented by the string ARND. 


\subsubsection{Mass Spectrometry}

Mass spectrometry is an analytical chemistry technique which is capable of determining the molecular composition of unknown sample molecules. Mass spectrometry is a widely used technique, common in fields such as water quality assessment, pharmaceuticals, proteomics, and lipidomics. For the purpose of this thesis, we will limit the scope of mass spectrometry data analysis to proteomics. Thus, we can assume that the input to any mass spectrometry experiment is a sample with an unknown mixture of proteins, and that the desired output of the experiment is the unique identification of as many proteins in the sample as possible or the determination of specific high-importance biomarker proteins.

The most common mass spectrometry pipeline is the tandem mass spectrometry pipeline, or MS/MS pipeline. The first step in the MS/MS pipeline is a digest of proteins into peptides - amino acid chains which are subsequences of an original protein sequence. Typically, protein digestion is performed by the enzyme trypsin, which cleaves proteins at specific peptide bonds - after any $\mathbf{R}$ or $\mathbf{K}$ amino acid which is not followed by a $\mathbf{P}$ amino acid. Thus, knowing the sequence of a protein, it is possible to predict all peptides which would be produced by a tryptic digestion.

Once a protein has been digested into peptides, these peptides are then ionized using either matrix-assisted laser desorption ionization (MALDI) or electrospray ionization (ESI) techniques. For our purposes, we will assume that ESI ionization is used for all experiments. The ionized peptides are then propelled through a chamber using an electric or magnetic field which imparts kinetic energy onto each peptide relative to the peptide's charge. The resulting velocity of a peptide is proportional to the mass-to-charge $(\mathrm{m} / \mathrm{z})$ ratio of the peptide. Using a detector at the end of the 
chamber, a mass-to-charge histogram of all peptide material in the mass spectrometer can be determined by measuring the time of flight of peptides or the amount of deflection in the path of the peptides. This histogram is represented by a $\mathrm{m} / \mathrm{z}$ spectrum, in which peaks correspond to the $\mathrm{m} / \mathrm{z}$ ratios of molecules which were abundant in the digested sample, i.e. peptides. Due to the presence of carbon in peptide molecules and the natural occurrence of $\mathrm{C} 13$ carbon isotopes, each peptide results in a cluster of peaks which are evenly spaced at a distance of $1 /($ charge of peptide). Thus, by measuring the separation distance within a cluster of peaks, it is possible to determine the charge of a peptide, and therefore the mass of the peptide. This process is known as de-isotoping.

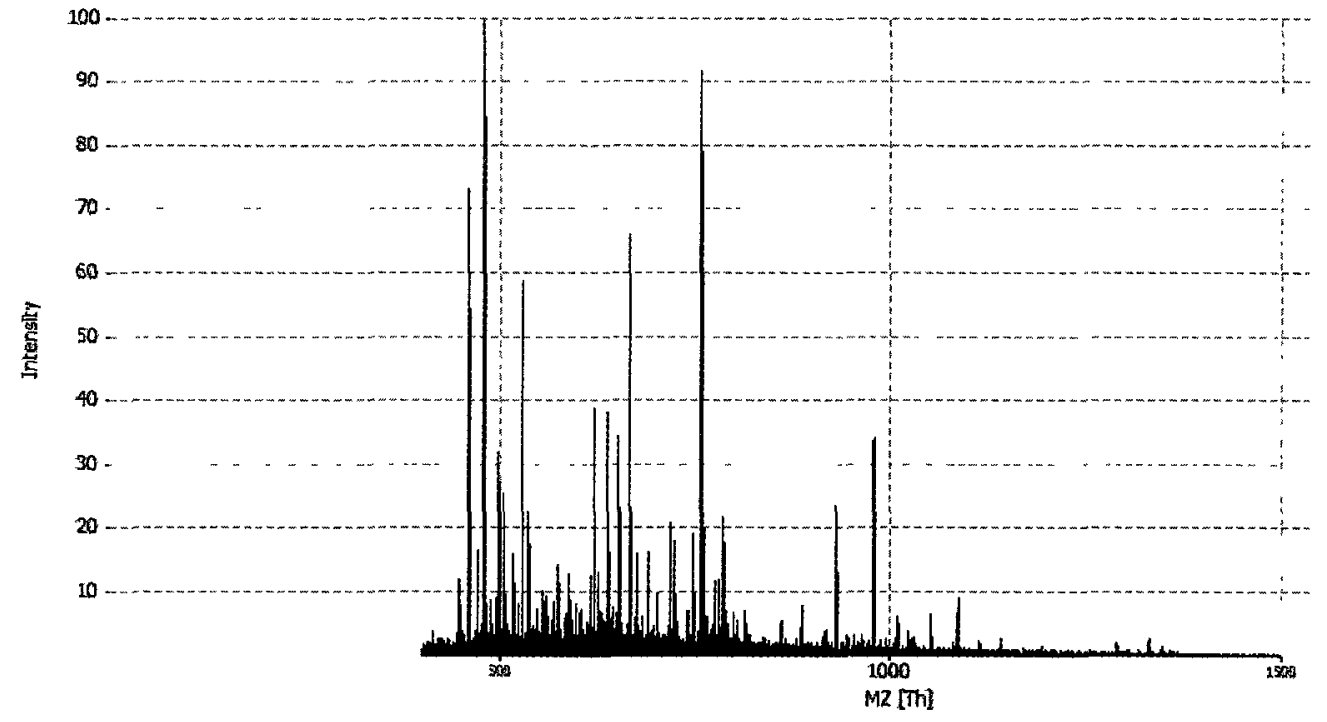

Figure 1-1 - A $\mathrm{m} / \mathrm{z}$ spectrum resulting from mass spectrometry

The production of $\mathrm{m} / \mathrm{z}$ spectra is the fundamental operation of mass spectrometry hardware. This operation is performed repeatedly throughout an experiment, at a rate of several spectra per second on a modern mass spectrometer. $\mathrm{M} / \mathrm{z}$ spectra which contain peptide peaks are used as an input for tandem mass spectrometry, which is detailed in the following section. 


\subsubsection{Tandem Mass Spectrometry}

Tandem mass spectrometry, or MS/MS, represents a second dımensıon of data collection in a mass spectrometry experıment. MS/MS extends the mass spectrometry pıpelıne by delving into specıfic peptıde peaks of a $\mathrm{m} / \mathrm{z}$ spectrum. A MS/MS experıment starts with the production of a standard $\mathrm{m} / \mathrm{z}$ spectrum, known as a survey ion scan. Once a survey ion scan has been performed, peptıde material with a specific $\mathrm{m} / \mathrm{z}$ ratio is extracted from the mass spectrometer. For example, upon generatıng the spectrum seen in Figure 1-1, the mass spectrometer is likely to extract all material with a $\mathrm{m} / \mathrm{z}$ ratıo of 1480 as thıs $\mathrm{m} / \mathrm{z}$ ratıo relates to an abundant peak in the spectrum. Once extracted, the material with the specific $\mathrm{m} / \mathrm{z}$ ratio which ideally consists only of a single peptide - enters a collisıon chamber. Inside thıs chamber, the peptıdes are broken Into smaller amıno acıd subsequences at random; breakage almost always occurs between amıno acıds because of the weak peptıde bonds between amıno acıds. The resultıng ıns are sent through the mass spectrometer agaın, resultıng in another $\mathrm{m} / \mathrm{z}$ spectrum, known as a product ion spectrum. Because the product ion spectrum contains only information relating to a single peptide and the total mass of the peptide is known from the survey ion scan, it is often possible to ascertain the identity of this peptide using the product ion spectrum information. Figure 1-2 demonstrates an overview of the MS/MS pipelıne as described in this section. 


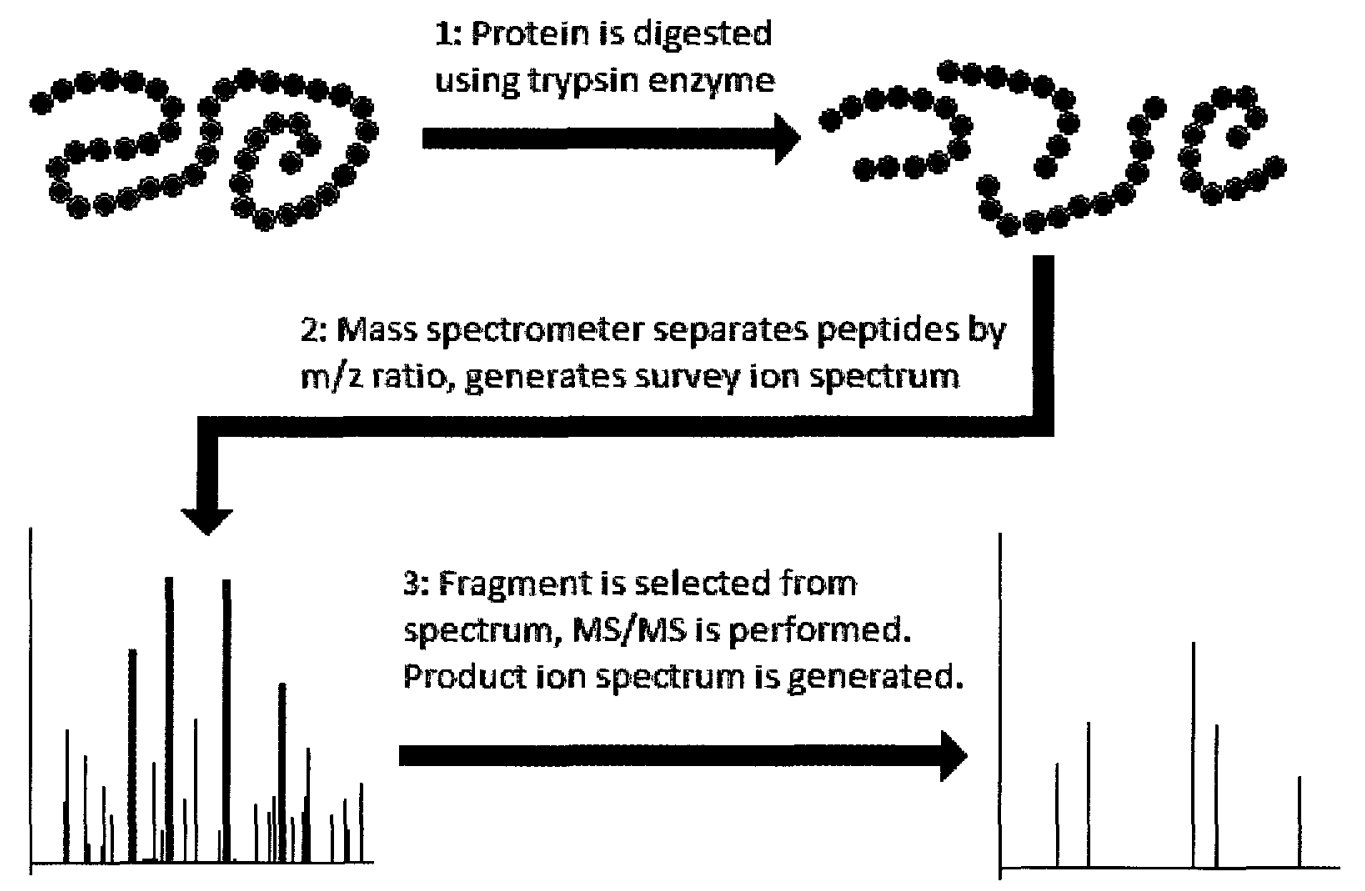

Figure 1-2 - Major steps in the MS/MS pipeline. Data is colour-coded by peptide; all four peptides appear in the survey ion scan, while the product ion scan is limited to a single peptide.

One commonly used technique for extracting peptide identification information from product ion spectra is de novo sequencing. In order to determine the identity of amino acids, de novo sequencing observes the distance between peaks in the product ion scan; because the peptide was fragmented at random, any inter-peak distance which corresponds to the mass of a single amino acid is likely to be caused by the presence of two subsequences of a peptide: one subsequence which contains the amino acid relating to the inter-peak distance, and another subsequence which is similar, but is missing the amino acid in question. That is to say, an inter-peak distance which matches an amino acid mass is evidence that that amino acid is present in the peptide. By finding concurrent inter-peak distances relating to amino acids, de novo sequencing develops a peptide sequence tag, a short sequence of amino acids which are known to be a part of the peptide. For example, in Figure 1-3, inter-peak distances corresponding to the sequence tag LVLY are seen in the 
product ion spectrum. Thus, the peptide is likely to contain the sequence LVLY. Peptide sequence tags are prone to ambiguity due to the isobaric nature of certain amino acids, i.e. GG and $\mathbf{K}$, and due to missing peaks in product ion spectra which result in pairs of amino acids whose order is uncertain.

Once a peptide sequence tag has been obtained, this tag can be searched against proteomic databases; all proteins which contain this peptide sequence tag are potentially present in the unknown protein sample. With the information gained from multiple peptide sequence tag searches, the identity of proteins in a sample can be determined. Proteins are not considered to be identified in a sample unless multiple peptide sequence tags confirm its identity - in mass spectrometry literature, protein identifications based on the strength of a single peptide sequence tag match are not considered to be well-founded.

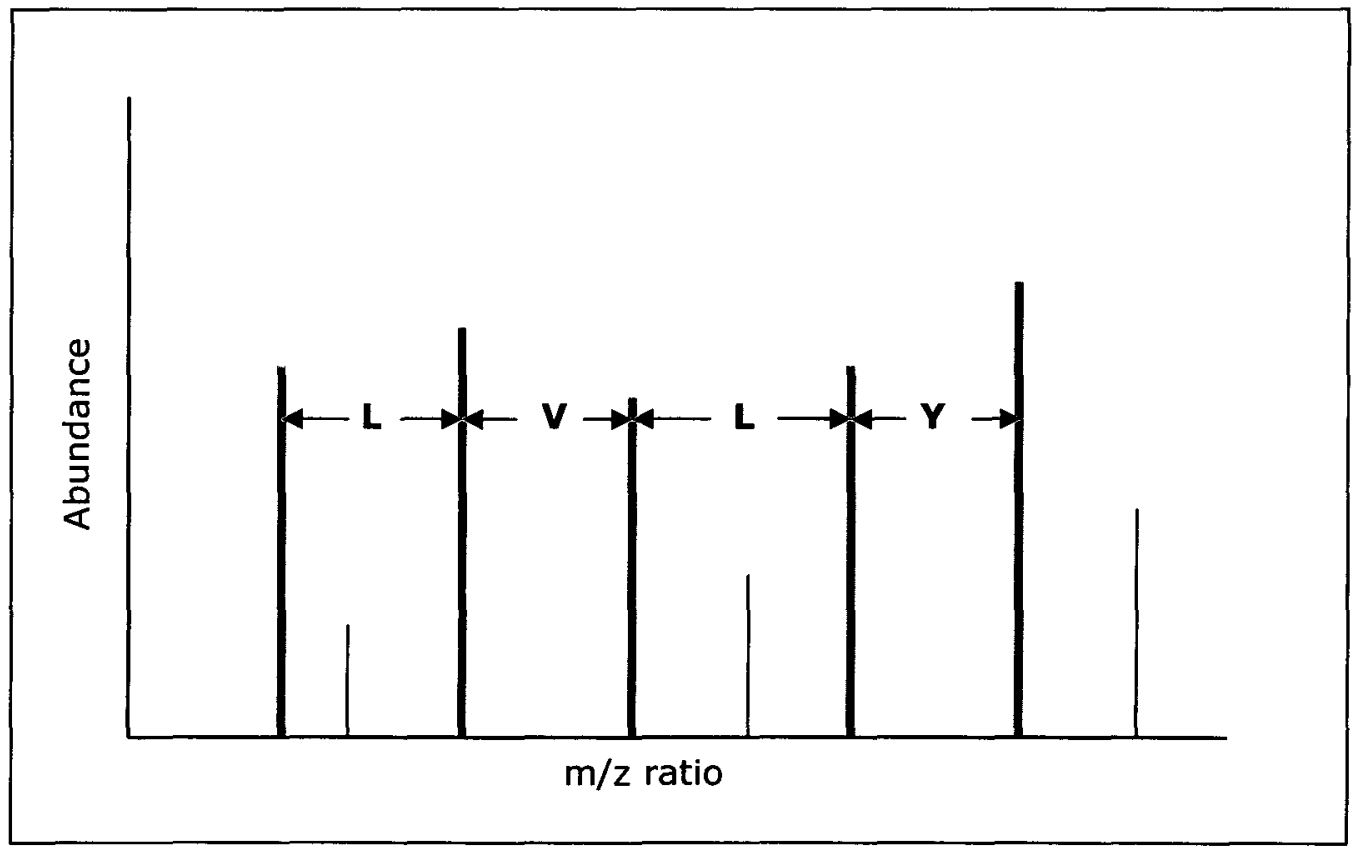

Figure 1-3 - De novo sequencing producing LVLY from a product ion spectrum 
A second technıque whıch determınes the identity of a peptıde based on spectral data is spectral matchıng, whıch correlates an experımental spectrum with databases of predicted peptide spectra. The strength of the correlation is based on the number of peaks in the database spectrum which share a mass with peaks in the experımental spectrum Spectral matchıng is not explored durıng thıs thesıs.

\subsubsection{Liquid Chromatography and Retention Time}

While the MS/MS pipelıne is capable of Identifying proteins through the use of product ion spectra, complex samples produce incomprehensıble survey ion spectra If all of the sample material enters the mass spectrometer at once. In order to reduce the complexity of survey ion scans, the MS/MS pıpelıne is commonly prepended with liquid chromatography, producing the LC-MS/MS pipeline. In this pıpelıne, peptıdes are not fed directly into the mass spectrometer after being digested, but are rather bound to a column which contaıns beads coated in a C18 resin. The column is immersed in a mixture of water and an organic liquid such as acetonitrile. This mixture flows from the column to the mass spectrometer contınuously for the duration of a LC-MS/MS experıment. Initially, the mixture contaıns only water; the hydrophobıcity of peptıdes prevents them from eluting from the column and into the mass spectrometer. Over tıme, however, an acetonitrile gradıent is introduced into the mixture. acetonitrıle gradıents are typically Iınear, and thus can be defined by a start tıme at which acetonitrile begins to flow and a set rate of increase in acetonitrile over tıme. As a result of the acetonitrıle gradıent, peptıdes elute from the column and into the mass spectrometer in roughly the order of their hydrophobıcıty; weakly hydrophobıc peptıdes elute early in the experıment, whıle strongly hydrophobic peptides elute toward the end of the experıment. Throughout the experıment, the mass spectrometer contınually cycles between producing a survey ion spectrum and producing product ion spectra from the most abundant 
peaks of the survey ion spectrum. Product ion spectra are aggregated for the duration of the experiment and stored in a flat file, which is analysed after the experiment in order to identify proteins from the initial sample.

LC-MS/MS as described above is the most widely used form of mass spectrometry experiment, and is the type of mass spectrometry experiment which we will focus on in this thesis. Figure 1-4 demonstrates an overview of the LC-MS/MS pipeline.

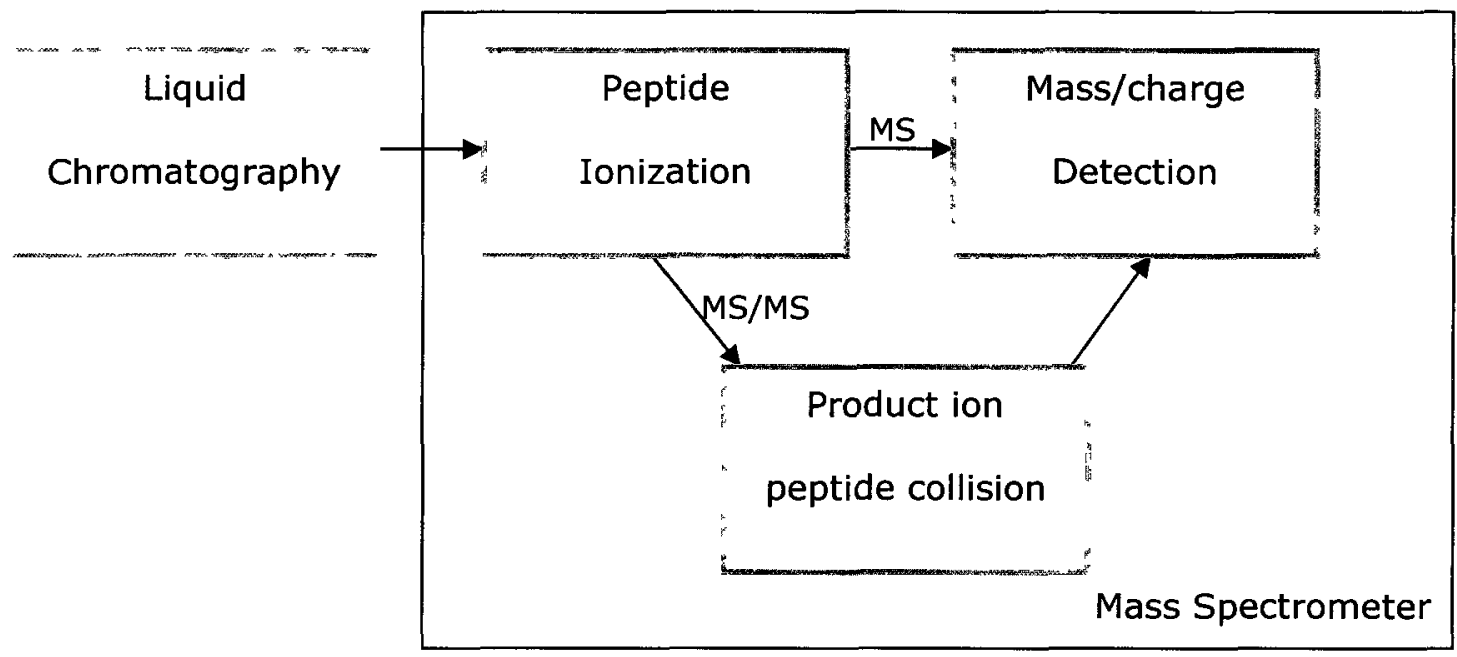

Figure 1-4 - Overview of the LC-MS/MS pipeline. Peptides travel from the liquid chromatography phase to the mass spectrometer, where they are ionized and then detected based on their mass/charge ratio. During a product ion scan, peptides pass through a collision chamber between ionization and detection.

With the advent of LC-MS/MS experiments, peptide retention time - the percentage of acetonitrile in solution at which a specific peptide will elute from a column into a mass spectrometer - has become an important physical property of peptides. This value is often referred to as the normalized elution time (NET) of a peptide, and ranges from 0 to 1 where a higher number represents later elution during a typical experiment. LC-MS/MS experiments are defined by an acetonitrile gradient (LC gradient) which occurs throughout the experiment; therefore, a well-defined relationship exists between the retention time of a peptide and its elution during an experiment. This relationship is non-trivial, however, as LC gradients are not always 
linear, retention tıme prediction is approxımate, and LC gradıents are not always known prior to an experıment. Because of the advent of the LC-MS/MS pipelıne, technıques whıch aım to predıct the retention tıme of a given peptıde based on the peptıde's sequence are now important elements of mass spectrometry data analysis. By performıng an in silıco digestion on a proteomic database, or by performıng in silico transcription, translation, and digestion of a genomic database, then calculatıng the mass and predicting the retention time of each resulting peptide, it is theoretically possıble to build an accurate mass/tıme (AMT) database which captures all of the expected survey ion spectrum peaks for a LC-MS/MS run. These databases can be viewed as a two-dımensional graph, as shown in Figure 1-5. We can picture a LC-MS/MS experıment as a 'scan' from left to right across thıs two-dımensıonal graph, where a subset of the peaks - correspondıng to the peptıdes present in the sample - are uncovered by the scan.

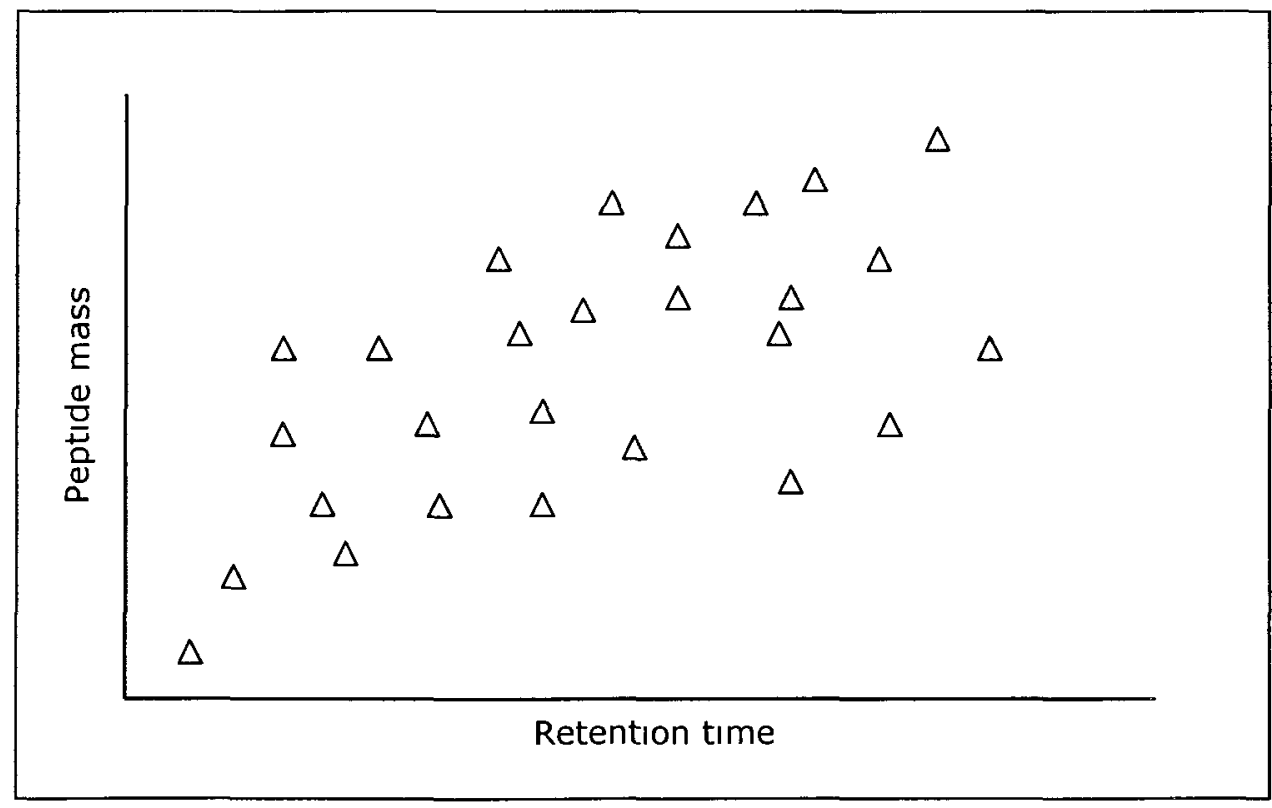

Figure 1-5 - An accurate mass/time database 


\subsubsection{Commodity Parallel Hardware Architectures}

Parallel computing has recently seen an increase in popularity, largely due to the advent of commodity parallel hardware architectures such as Sony/Toshiba/IBM's Cell Broadband Engine (Cell B/E) and general purpose programming on graphics processing units (GPGPU) using the Nvidia CUDA platform.

\subsubsection{The Cell Broadband Engine}

The Cell Broadband Engine (Chen, Raghavan, Dale, \& Iwata, 2007), a heterogeneous multi-core processor, was released in 2006 by Sony, Toshiba and IBM. This architecture was originally designed to power the Playstation 3 console, however it has seen success for parallel scientific computing (Bader \& Agarwal, 2007) (Petrini et al., 2007), powering parallel clusters such as the US Department of Energy Roadrunner cluster, which was the first computer to break the petaflop/s barrier and the world's fastest supercomputer from June 2008 through June 2009 (Los Alamos National Security, LLC for the U.S. Department of Energy's NNSA, 2010-2011).

The Cell $B / E$ incorporates a single general purpose 64-bit Power Processing Element (PPE) and eight high-throughput Synergistic Processing Elements (SPEs) onto a single chip. These nine processors are connected with a ring bus, the Element Interconnect Bus (EIB).

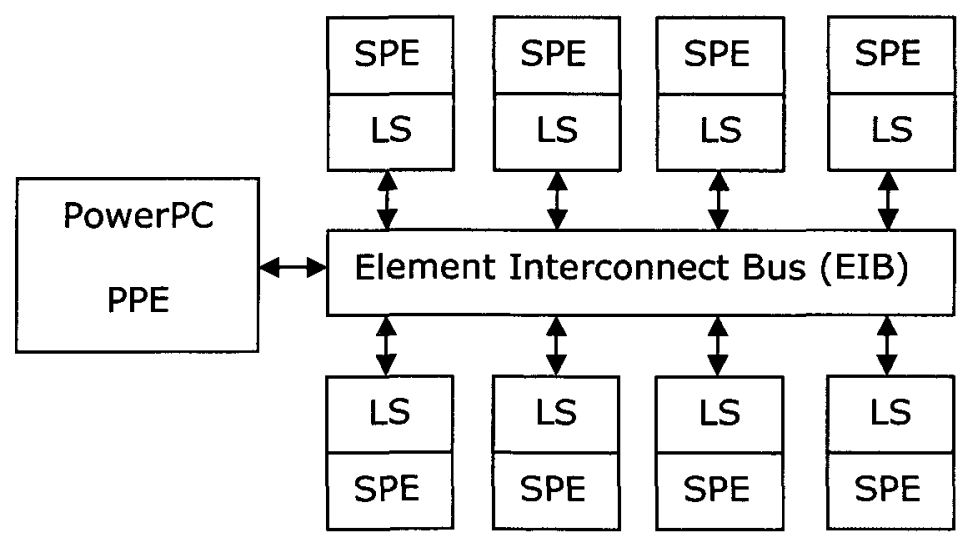

Figure 1-6 - Overview of the Cell B/E architecture 
Typically, the PPE is used only for task management, as the PPE is responsible for launchıng and coordınating SPE kernel threads. The bulk of computation is performed by the SPES, which are highly tailored to data-intensive computıng. Each SPE IS capable of 128-bit-wide SIMD operations at $3.2 \mathrm{GHz}$, and each SPE is outfitted with a memory management unit which handles data transfer independently of computation. All SPE data, including heap, stack, and instructions, are stored in a 256KB local store (LS) which is integrated into each SPE. Each SPE is capable of runnıng kernels Independently; the 8 SPEs can each perform a separate function at one tıme. The Element Interconnect Bus, which is responsıble for all memory transfer withın the Cell $B / E$ chıp, takes the form of four unı-dırectıonal rıng buses whıch when fully utilized provide a theoretical peak bandwidth of $307.2 \mathrm{~GB} / \mathrm{s}$.

\subsubsection{The CUDA Platform}

Nvidia's CUDA platform (http://www.nvidia.com/object/cuda_home_new.html) for GPGPU is the result of a recent trend toward the use of graphics processing units for parallel processing of scientific data. The CUDA platform allows graphics cards to be programmed dırectly, usıng a C-lıke applıcatıon programmıng interface (API). Sımılarly to the Cell $\mathrm{B} / \mathrm{E}$ architecture, the CUDA programmıng paradıgm revolves around an all-purpose processor, the CPU, which launches and coordinates GPU threads (known as kernels) on multıple hıgh-throughput processors on the GPU. However, the main difference between the Cell B/E and CUDA platforms is that a typical CUDA GPU has hundreds of simpler processors. The GPU architecture is domınated by a series of multıprocessors, each of which contaıns a sıngle instruction unit, several SIMT (single instruction multiple thread) processors, and a number of caches. All of the multıprocessors are connected to the GPU maın (device) memory, which is in turn connected to the CPU main memory through the PC's main bus. 


\subsection{Motivation}

Whıle MS/MS represents the state of the art for many important bıochemical tests, most notably protein identification, current mass spectrometry techniques are fundamentally limited by a disconnect between data acquisition and data analysis. MS/MS data analysıs technıques have seen great ımprovements in the past few years, makıng use of new technologies and technıques, however these techniques can only work with the data given to them, and MS/MS data acquisition makes use of relatively crude algorithms for survey peak selection The most common form of survey peak selection algorithm for MS/MS is abundance-driven MS/MS, wherein precursor ions are chosen based only on their abundance in the mass spectrometer at the time of the latest survey scan. This method of survey peak selection is clearly sub-optımal, especially when low-abundance bıomarkers are present in a sample which could be important to protein identification. Figure 1-7 demonstrates the abundance driven MS/MS pipelıne.

An ınformatıon-driven MS/MS pıpelıne, whereın data analysıs is performed durıng the experıment and precursor ions are selected based on the likelıhood that they will uniquely identify proteıns, could improve the data acquisitıon stage of mass spectrometry experıments. Previous work has proven that state of the art MS/MS hardware only captures a fraction of possıble precursor Ions (Mıchalskı, Cox, \& Mann, 2011), demonstratıng a need for intelligent precursor ion selection. Additionally, it has been proven that the move from abundance-driven to even a simple Information-driven MS/MS pıpelıne would ıncrease the number of unıque proteın Identıfications durıng an experıment (Zerck et al., 2009). This work, however, was done only on sımulated experıments. A complete ınformation-driven MS/MS data analysıs pıpelıne has not been ımplemented at thıs tıme. 


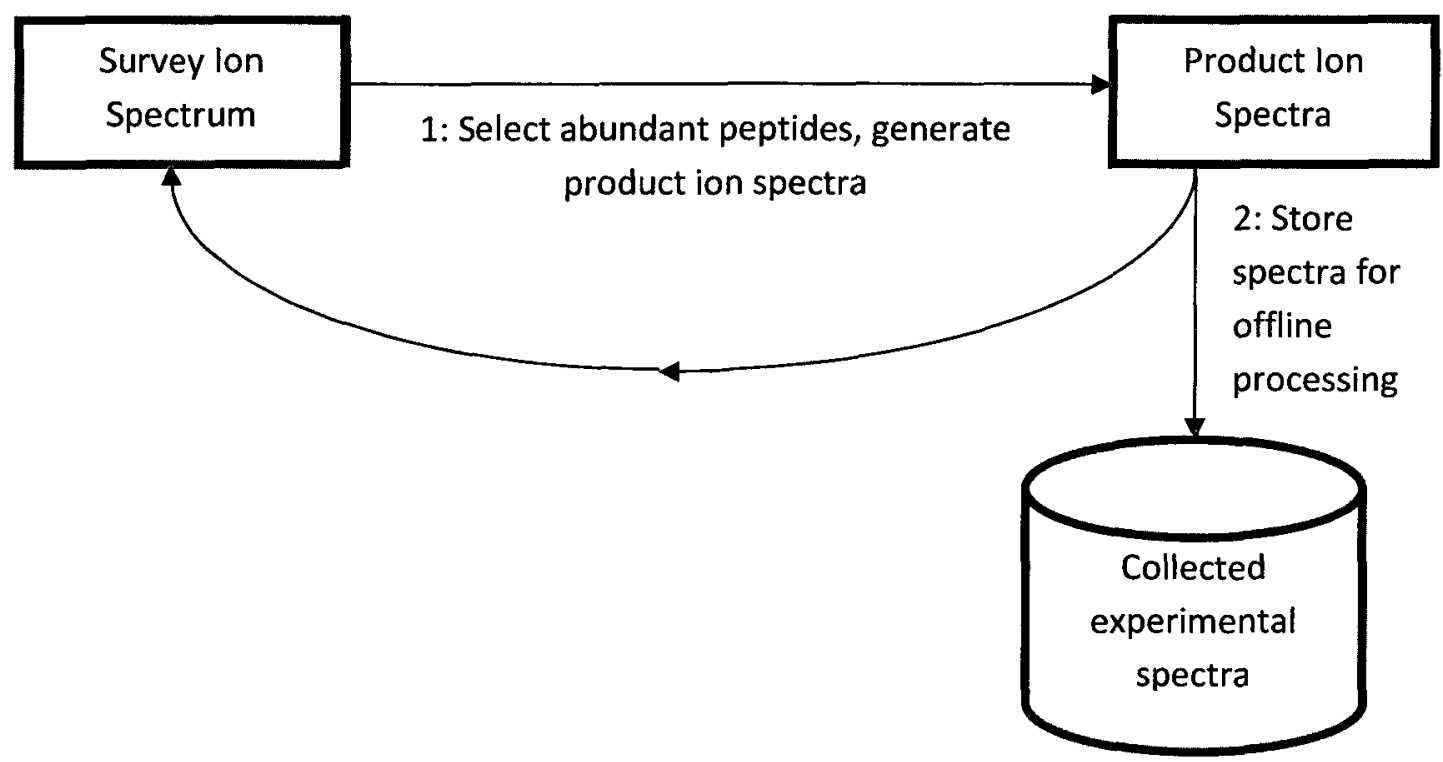

Figure 1-7 - Abundance-driven MS/MS pipeline. Product ion scans are repeated on high-abundance peptides for the entirety of the experiment.

The move toward online "in-the-loop" data analysis techniques introduces several major challenges which are not present in the current paradigm of MS/MS data analysis. Chief among these challenges is the real-time deadlines introduced by the mass spectrometry hardware; current mass spectrometry hardware produces multiple spectra every second, and each iteration of the idMS/MS data analysis loop must be performed between the production of spectra. Therefore, an entire cycle of MS/MS data analysis must be performed within a fraction of a second in order for idMS/MS to become possible.

Fortunately, recent developments in commodity parallel hardware allow for highthroughput data intensive computing which could potentially meet the real-time deadlines imposed by the mass spectrometer without the need for complex hardware setups or advanced technical knowledge. Platforms such as the Cell Broadband 
Engine (Cell B/E) and general purpose programming on graphics processing units (GPGPU) usıng CUDA will facilitate IdMS/MS once a full pıpelıne is implemented.

As can be seen in Figure 1-8, the IdMS/MS pipeline contains several critical steps, all of which must be performed in series withın the mass spectrometer's real-tıme deadlıne. Untıl the point where enough Information has been gathered to perform Informatıon-driven MS/MS, product Ion spectra are selected using an abundancedriven methodology (step 1). When a product ion spectrum is generated by the mass spectrometer, de novo sequencing is performed on the spectrum (step 2), producing a peptide sequence tag which can then be searched against a proteomic database (step 3). All proteın matches for the peptıde sequence tag are recorded, and the list of all proteıns for which there is evidence of their existence is used to determine a score for each of the peaks of the latest survey ion mass list (step 4). When a survey Ion spectrum is generated by the mass spectrometer, the peaks of the spectrum are converted into a survey ion mass list. Using the retention tıme / experıment tıme mapping module, the current best-guess retention time is determined based on this mass list (step 5). The current retention tıme is also used as a factor for determınıng the score of each peak. Once all of the peaks have been scored, high-scorıng peaks are then chosen for future product ion scans (step 6).

Step 3 of the pıpelıne, searchıng genomic or proteomıc databases for peptıde sequence tags, clearly represents the challenge of parallelızation of data-ıntensive analysıs. Additıonally, searchıng peptıde sequence tags across proteomıc or genomic databases is analogous to exact strıng matchıng; genomic or proteomic databases are stored as flat files on disk and moved into memory during searching, and are typically in the range of hundreds of megabits in size. Exact string matchıng, and by extension peptide sequence tag matching, is a problem which is prevalent in 
computer science literature and which can be benchmarked in a straightforward manner. These factors make step 3 an ideal first step toward parallel MS/MS data analysis.

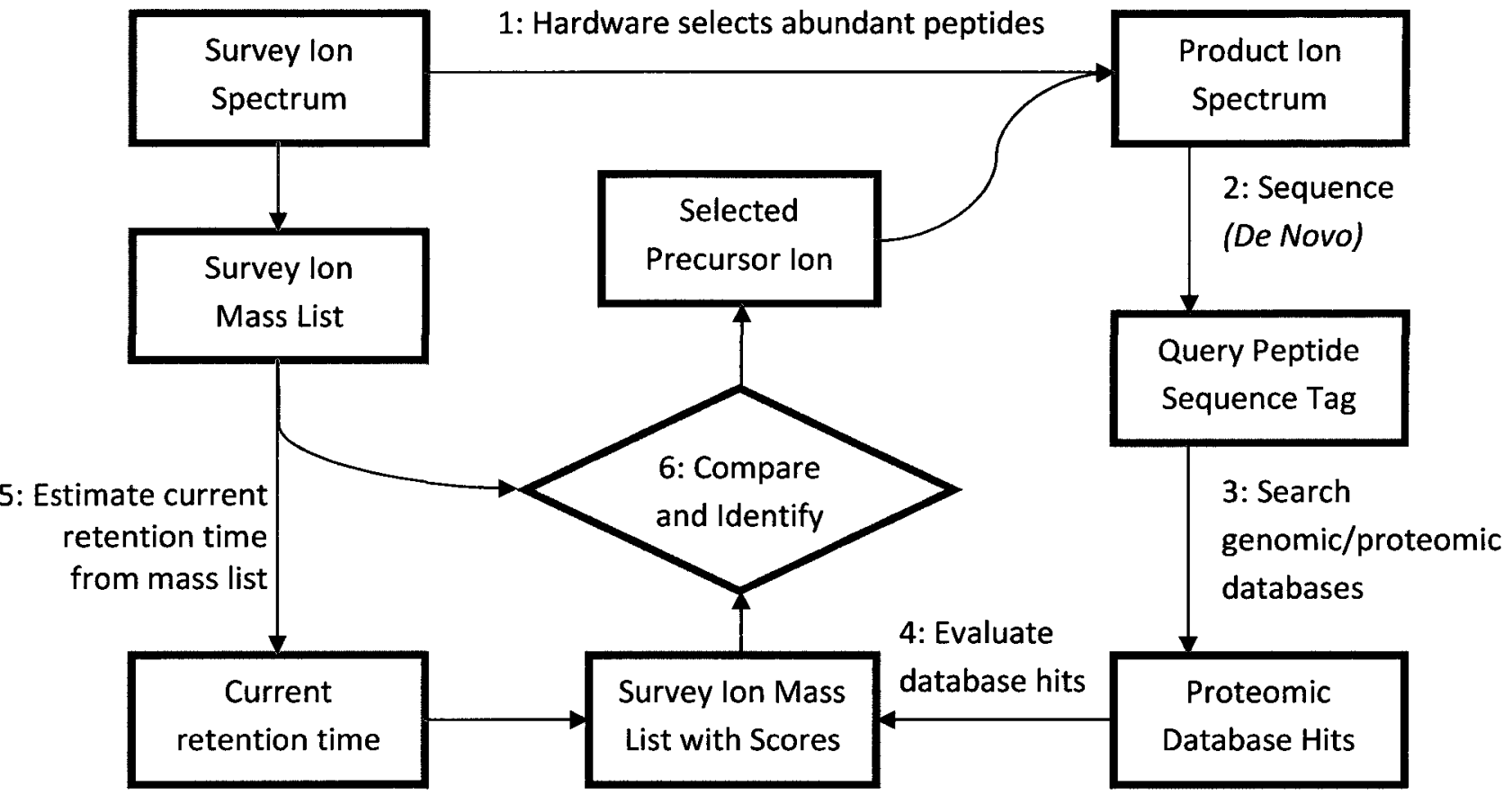

Figure 1-8 - Information-driven MS/MS pipeline. Hardware products are highlighted in red, while idMS/MS products are highlighted in blue.

Challenges inherent in moving MS/MS data analysis online cannot all be solved through parallelization, however. In developing an idMS/MS pipeline, it becomes apparent that knowing the current retention time of the experiment is essential to successful precursor ion selection - peptides which are currently being eluted into the mass spectrometer are more relevant than peptides which have already eluted and passed through the instrument. Prior MS/MS data analysis techniques did not require a knowledge of retention time until the experiment was completed and all data could be looked at as a whole, so a novel approach was required in order to map retention time to experiment time using data as it is produced by the mass spectrometer. This time mapping algorithm is also useful outside of the idMS/MS pipeline, as it would allow directed MS/MS experiments (whose goal is to find 
evidence of specific proteıns) to locate peptıdes along the tıme scale of an experıment without the need for input from mass spectrometry technicians. Current techniques for the prediction of the elution tıme of peptıdes, such as SSRCalc (http://hs2.proteome.ca/SSRCalc/SSRCalcX.html), require that instruments be calıbrated precisely and that LC gradients be known prior to the experıment, two requirements whıch are not present for our tıme-mappıng algorıthm.

\subsection{Statement of the Problem}

Given IdMS/MS' potential for Improvement of MS/MS data analysıs and the wide avallability of commodity parallel hardware, we feel that the production of an IdMS/MS pıpelıne is an Ideal candidate for the advancement of proteın Identıfication. Thıs thesis presents two major contributions whıch are essential to the production of the IdMS/MS pıpelıne.

In order to gauge the suitability of the Cell B/E and CUDA platforms for dataintensıve MS/MS analysıs, while at the same tıme developıng a critıcal element in the IdMS/MS pıpelıne, we aım to ımplement a novel strıng matchıng algorithm whıch is hıghly taılored to the task of searchıng peptıde sequence tags over large genomic or proteomic databases. This algorithm should be capable of searchıng six-frame genomic databases, and should be able to handle ambıguitıes which are commonly seen in peptide sequence tags. Once implemented on both the Cell B/E and CUDA platforms, the peptide sequence tag matching algorithm will provide evidence as to which parallel hardware platform is the ideal candidate for IdMS/MS implementation.

In addition to the peptıde sequence tag matching algorıthm, we seek to develop a novel algorithm for the purpose of mapping an experıment's current wall tıme to the calculated retention tıme value of the experıment. Thıs algorithm will calculate the 
current retentıon tıme of an experıment in real tıme, usıng only data which is avalable from the mass spectrometer during the experıment. Because the amount of data avallable to the algorithm is lımited, a non-parametric probability-based model is likely to be ideal for this problem. As a step toward the development of this algorithm, we aım to develop a real-tıme retention tıme prediction method which strikes a balance between prediction accuracy and computational intensity.

\subsection{Contributions}

Chapter 3 presents several contributions related to the problem of peptide sequence tag matching on the Cell $\mathrm{B} / \mathrm{E}$ hardware. The primary contribution of this chapter is the development of the orthogonal Parabix algorithm for the Cell B/E. This novel extension to the Parabıx algorithm (Cameron, Herdy, \& Lin, 2008) is well-suited to the task of peptıde sequence tag matchıng, and far outperforms all exıstıng strıng matchıng algorithms for thıs task. The orthogonal Parabıx algorithm as ımplemented on the Cell B/E sustains a search throughput of $215.4 \mathrm{Gbit} / \mathrm{s}$. When compared to general purpose string searchıng methods, the orthogonal Parabıx algorıthm provides a speedup of approxımately $124 \mathrm{x}$. In comparıng the Cell B/E Implementation of the orthogonal Parabıx algorithm to an equivalent serial implementation, we see speedups of over $10 x$.

Chapter 3 also presents the first ımplementations of establıshed strıng searchıng algorıthms on the Cell $B / E$, Includıng the Boyer Moore and Rabın Karp algorithms. Note that Initial development of the Cell B/E Implementatıons of existıng string searching algorithms was performed during a 4th year undergraduate project. This thesıs dıd, however, Improve on these Implementations, Increasing search throughputs. Chapter 3 forms the basıs of the journal artıcle, "Exact Strıng Matchıng 
for MS/MS Protein Identification using the Cell Broadband Engine" (Peace, Mahmoud, \& Green, 2011).

The primary contribution of chapter 4 of this thesis is the implementation of the orthogonal Parabix algorithm on the CUDA platform. This implementation, running on a Nvidia GTX570 graphics card, achieves a sustained search throughput of 2066.4 Gbit/s - an order of magnitude greater than those seen on the Cell B/E platform. This implementation also breaks the $100 x$ speedup barrier when compared to an equivalent serial implementation.

In addition to the increased throughput, the CUDA implementation of the orthogonal Parabix algorithm improves on the original implementation in several ways. The CUDA implementation is capable of searching six-frame genomic databases without affecting the search throughput, and handles ambiguous peptide sequence tags in such a way that false positive results are minimized while search throughput remains comparable to throughputs for unambiguous queries.

Chapter 4 presents a novel algorithm which applies probabilistic models to the problem of mapping wall time to retention time as a LC-MS/MS experiment is performed. This algorithm builds on the idea of the AMT database as a probability density space by employing Parzen window techniques and function maximization in order to estimate the current retention time which best matches the evidence provided by the mass spectrometer as the experiment is being performed. This approach was able to accurately predict the retention time of a set of 9 confidently identified peptides during a real LC-MS/MS experiment with a mean squared error of 0.00627 . 
As a step in the process of developing the retention time / wall time mapping algorithm, we have developed a novel ANN topology which balances prediction accuracy and computational intensity. This ANN is capable of predicting peptide retention with a high $R^{2}$ value of 0.9483 usıng only 23 inputs and 10 internal nodes. This ANN topology outperforms ANNs of simılar size by a significant margın.

\subsection{Organization of Thesis}

This thesis consists of 6 chapters. Chapter 2 briefly discusses the current state of the art regardıng mass spectrometry data analysıs, parallel string searchıng, peptıde retention tıme predictıon, accurate mass/tıme databases for mass spectrometry, and commodity parallel hardware.

In chapter 3, we present peptıde sequence tag searchıng on the Cell B/E, Includıng Implementatıons of establıshed strıng matching algorithms on the Cell $B / E$ and the novel orthogonal Parabıx algorıthm.

In chapter 4, we present peptide sequence tag matching efforts on the GPU, Including improvements to the orthogonal Parabıx algorithm in order to allow for searchıng of genomıc databases and better handlıng of ambiguous peptıde sequence tag queries.

Chapter 5 detalls the creatıon of the retention tıme / experıment tıme mappıng algorithm, which is accomplished through novel use of statıstical techniques in the domain of mass spectrometry.

Chapter 6 presents a summary of contributions and provides recommendations for future work. 


\section{Literature Review}

This chapter details the state of the art in fields which are impacted by this thesis. Fields covered in this chapter include data analysis for mass spectrometry, accurate mass/time databases, retention time prediction, and exact string matching on commodity parallel hardware.

\subsection{Computational Methods for Mass spectrometry}

Mass spectrometry methods can be broadly separated into two categories: experimental methods, which aim to improve the spectral outputs of mass spectrometry hardware through the use of chemical and physical techniques; and computational methods, which aim to improve the interpretation of spectral data via data analysis techniques.

Recent efforts in computational methods for mass spectrometry have focused on steady improvement of spectral analysis of MS/MS product ion spectra, as can be seen in computational mass spectrometry reviews over past years: (Aebersold \& Mann, 2003), (Nesvizhskii \& Aebersold, 2004), (Sadygov, Cociorva, \& Iii, 2004), (Johnson, Davis, Taylor, \& Patterson, 2005), (Nesvizhskii, Vitek, \& Aebersold, 2007), (Deutsch, Lam, \& Aebersold, 2008). The major themes running through these reviews are computational techniques which improve the statistical identification of proteins based on a given set of spectra, and the presentation of data to mass spectrometry technicians. Quantitative analysis of spectral data is also explored during this time (Mueller, Brusniak, Mani, \& Aebersold, 2008), however this type of analysis is not mature at present. 
Accurate proteın identification through comparison of spectra with MS/MS databases is a domınant driving force in computatıonal mass spectrometry; many prominent computational mass spectrometry suites fill this role, includıng MASCOT, SEQUEST, X'Tandem. These packages are summarized by Kapp et al. (Kapp et al., 2005). De novo sequencing combıned with peptide sequence tag searches agaınst proteomıc databases (Seıdler, Zınn, Boehm, \& Lehmann, 2010) compete directly with MS/MS spectral database search engınes; examples of de novo sequencing tools include Lutefısk (Johnson \& Taylor, 2002), Pepnovo (Frank \& Pevzner, 2005), and Peaks (Ma \& Lajole, 2009).

A particular focus in recent computational mass spectrometry efforts has been the creation of integrated, robust mass spectrometry software suites which incorporate several data analysıs techniques into coherent toolsets that are designed for endusers of mass spectrometry hardware. One of the largest such initiatives has been the OpenMS project (Sturm et al., 2008). This open source project was developed around TOPP, the open proteomics pıpeline (Kohlbacher et al., 2007), and TOPPView, a software tool for visualization of mass spectrometry data (Sturm \& Kohlbacher, 2009). OpenMS is indicative of the recent emphasis on usability in computational mass spectrometry technıques.

Non-redundant mass spectrometry technıques, precursors to information-driven mass spectrometry, have been explored durıng recent years. These techniques use data analysis to guide product ion selection; however applications of these technıques are lımited due to theır lack of real-tıme data analysıs. Scherl et al. developed a "non-redundant" mass spectrometry system (Scherl et al., 2004) whıch works in conjunction with a MALDI MS/MS experiment for which the sample is separated prior to MS/MS analysis. During such a MALDI experiment, it is possible to examıne any portion of the proteın sample at any point in the experıment, so the 
real-tıme requirements of popular ESI LC-MS/MS experıments are elımınated. Thıs process was successful, however non-redundant MS/MS experıments are tıme consuming and MALDI is considered to be an outdated ionization technique compared to modern ESI. Zerck et al. have explored the effectiveness of a nonredundant LC-MS/MS experıment through sımulation (Zerck et al., 2009). Although this experıment used a sımple model for scorıng the ımportance of selectıng certaın peptıdes, they still improved the average confidence of proteın identifications and the number of Identıfied proteıns durıng an experıment. Parallelızation of MS/MS data analysıs for the purpose of IdMS/MS has seen lımited exposure, including parallelızation of peptide sequence tag searching usıng FPGA hardware (Alex, Dumontıer, Rose, \& Hogue, 2005), parallelızatıon of spectral processing using FPGA hardware (Bogdan, Coca, \& Rivers, 2007), and the successful implementation of a spectral matching algorithm whıch could serve as an alternative to de novo sequencıng and peptıde sequence tag matchıng (Zhang, McQuillan, \& Wu, 2011).

\subsection{Accurate Mass/Time Databases}

As an alternatıve to LC-MS/MS experıments, several groups have experımented with the use of AMT databases combined with high-accuracy survey scans in order to unıquely identıfy peptıdes dırectly from spectral data. Relatıve to spectral database searchıng technıques and de novo sequencing technıques for LC-MS/MS experıments, the use of AMT databases for high-resolution LC-MS experıments is not a mature technology; hıgh-qualıty data analysıs pıpelınes whıch utılıze AMT databases for peptıde identıficatıon are not avaılable on the scale of spectral matchıng- or de novo sequencing-based pipelınes. AMT LC-MS pipelınes are not currently practıcal for all laboratories due to limitations in mass spectrometry hardware resolution as well as the accuracy of current retention time prediction modules; therefore, efforts in this field focus largely on the development of statistical models for peptide identification 
via AMT database. The concept of accurate mass/time databases is based largely on previous efforts in the field of accurate mass tags, which is described by Conrads et al. (Conrads, G a Anderson, Veenstra, L Pasa-Tolić, \& R D Smith, 2000).

A popular probabilistic method for AMT LC-MS identification confidence is the spatially localized confidence (SLiC) scoring method which treats the problem of identifying a peptide as a statistical classification problem, as developed by Anderson, Monroe, Daly, and Valafar (K. K. Anderson, Monroe, Daly, \& Valafar, 2004). Norbeck et al. have explored the resolution and retention time accuracy required in order for AMT LC-MS to successfully identify peptides given the complexity of the proteome which is being searched (Norbeck et al., 2005). This work, which is built on the SLiC method, estimates that a mass spectrometer with mass accuracy of $1 \mathrm{ppm}$ would be capable of identifying only $50 \%$ of the human proteome through AMT approaches; only top of the line Fourier transform ion cyclotron resonance (FC-ITR) mass spectrometry hardware is capable of $1 \mathrm{ppm}$ mass accuracy given proper external calibrated. Zimmer et al. provide a comprehensive review of AMT LC-MS techniques (Zimmer, Monroe, Qian, \& Richard D Smith, 2006) which contains a more optimistic estimation of proteome coverage; they estimate that FC-ITR mass spectrometry hardware is capable of identifying approximately $70 \%$ of a typical mammalian proteome.

While AMT LC-MS is not yet applicable to databases which are as complex as the human proteome, the technique has been successfully applied to smaller databases with success. Anderson, Monroe, and Daly were capable of matching the identification accuracy of spectral database techniques for the identification of bovine serum albumin against a database which contained approximately 30 proteins (K. K. 
Anderson, Monroe, \& Daly, 2006), however this database is not on the scale of complete mammalian proteomes.

A recent improvement to the AMT LC-MS pIpelıne is the use of reference maps for enhanced retention time accuracy. This method incorporates strong cation exchange fractıonatıon into a mass spectrometry pıpelıne in order to provide calıbration runs prior to the experiment proper, thereby increasing the instrument's resolution. Kım et al. demonstrate that thıs enhanced AMT LC-MS pıpelıne Is capable of Identıfyıng T47D breast cancer lıne proteıns with a $98.3 \%$ correct ıdentıfıcatıon rate (Kım et al., 2009). This study is representative of recent successes of AMT LC-MS pıpelınes for proteın Identification.

In addition to the development of AMT LC-MS pipelınes which do not examıne product ion spectra, AMT databases and associated techniques have been used in conjunction with traditional LC-MS/MS data analysıS pıpelınes. AMT-enhanced LCMS/MS technıques such as those suggested by May et al. (May et al., 2008) demonstrate the utılıty of AMT databases outsıde of specific AMT LC-MS experıments. Thıs work also introduces a novel probabilıstıc scorıng method for matchıng experımental results to AMT databases.

\subsection{Retention Time Prediction}

The retention time prediction problem is a regression problem for which the input is an arbitrary peptide sequence and the output is a value which represents the chromatographic conditıons under which the peptıde will elute from a column in a lıquıd chromatography experıment. Retention tıme predıctıon is an ımportant factor of AMT workflows, as retentıon tıme measurements are lımited by the abılity to accurately predict retention times of database peptides. A recent review of retention 
tıme predictıon by Babushok and Zenkevich summarızes the major technıques for retention tıme predıctıon (Babushok \& Zenkevıch, 2010).

The most mature technique for peptıde retention tıme prediction is the use of artificial neural networks (ANNs) for linear regressıon. These ANNs use as inputs peptıde sequence information, and are trained on large data sets which represent the observed elution tımes for a wide range of peptıdes over multıple mass spectrometry experıments. The first such technıque was proposed by Petritıs et al., and contaıned 20 Inputs, each relatıng to the frequency of each amıno acıd over the length of the peptıde sequence (Petritıs et al., 2003). This technıque achıeved an $R^{2}$ value of 0.87 on a test set of 1303 confıdently identıfied peptıdes. Petritıs et al. later Improved on their model by receiving as ANN Inputs an orthogonal encoding of the entire peptide and a small set of statıstıcally derıved features (Petritıs et al., 2006). This model produced an $\mathrm{R}^{2}$ value of 0.967 on the same test set. The thırd major effort in using ANNs to predict peptide retention tıme is based on Petritıs' 20-input model, however In this model four of the amıno acid inputs are removed due to having near-neutral hydrophobıcity values (Shınoda et al., 2006). Thıs model predıcts peptıde retention time with an $R^{2}$ value of 0.928 . While performıng slightly worse than Petritıs' 2006 method, the reduced complexity of the network may lead to better generalization to new data.

Complementary to the ANN technique described above is the family of quantitative structure-retention relatıonshıp (QSRR) techniques. These technıques utılıze statıstıcally derived chromatographic parameters which are derived from peptide sequence informatıon, as opposed to utılızıng peptıde sequence information directly. Early papers in the QSRR field focused on the identification of statıstıcally relevant parameters (Put, Daszykowskı, Baczek, \& Vander Heyden, 2006), whıle more recent 
papers have focused more on the development of models usıng parameters which are known to be relevant. An example of a state of the art QSRR model is the ELUDE model, which uses support vector regression (SVR) and an input vector of 60 statıstıcally derived parameters (Moruz, Tomazela, \& Ka, 2010). ELUDE was tested on several data sets, resulting in Pearson correlation coefficients between 0.92 and 0.97.

A common criticism toward ANN models for retention time prediction is the need for large traınıng data sets whıch are produced through myrıad experıments, all of whıch need to be temporally alıgned. Thus, efforts have been made in order to produce models which are capable of accurately predıctıng retentıon tıme on a specific ınstrument given a small traınıng set of experımental peptıdes whıch were recorded by the instrument in question. These efforts have seen some success through the use of SVR. Klammer et al. were able to predict retention time with an $\mathrm{R}^{2}$ value of 0.908 using a SVR model with 63 peptide sequence inputs and a small traıning set produced by a linear trap quadrupole instrument (Klammer, YI, Maccoss, \& Noble, 2007). Pfeifer et al.'s olıgo-border kernel method for SVR achieved an $R^{2}$ value of 0.88 for peptıde retentıon tıme predıctıon usıng a lımıted traınıng set derıved from the large Petritıs data set (Pfelfer, Leınenbach, Huber, \& Kohlbacher, 2007). The olıgo-border kernel method has been Incorporated into the OpenMS software suite (Sturm et al., 2008) as the RTPredict module. This module permits users to train a model to mımıc their own Instrument, however the collection of an instrumentspecific traınıng set is a barrier to adoption.

The SSRCalc retention time prediction algorithm (Krokhın, 2006) is a popular algorithm due to its simple web interface as seen at http://hs2.proteome.ca/SSRCalc/SSRCalcX.html. Thıs interface represents a typıcal 
retention tıme prediction interface; experıment-specific information is required and only linear LC gradıents are accepted. The SSRCalc algorithm is in the QSRR famıly, and provides an $\mathrm{R}^{2}$ value in the range of 0.95 to 0.97 for most test sets.

\subsection{Exact String Searching on Parallel Architectures}

Parallel hardware, Including commodity parallel hardware such as the Cell B/E and GPU platforms, Is commonly used for high-throughput exact strıng matchıng and regular expression matching. The driving force behınd most high-throughput strıng matching algorithms is network intrusion detection (Vasiliadis, Antonatos, Polychronakıs, Markatos, \& S. Ioannıdıs, 2008) (Scarpazza, Vılla, \& Petrını, 2008b); large volumes of network traffic must be searched for expressions which are Indıcatıve of malıcıous traffıc. Thus, nearly all parallel exact strıng matchıng and regular expression matching algorithms are variatıons of the Aho-Corasıck algorithm (Aho \& Corasıck, 1975) which uses a discrete finıte automaton to search streamıng databases in constant time with respect to the number of search queries. A number of Implementatıons of the Aho-Corasıck algorithm are described below.

On the Cell B/E platform, the IBM T. J. Watson Research Center is responsible for almost all leadıng strıng matchıng ımplementatıons. Thıs group focuses mostly on the exact matching subset of string matching problems as opposed to regular expression matchıng. Theır ınıtıal efforts in thıs area (Scarpazza, Vılla, \& Petrını, 2007) produced an Implementation of the Aho Corasıck algorithm which had a theoretıcal lımit of $40.88 \mathrm{Gbit} / \mathrm{s}$ on a sıngle Cell B/E processor. The algorithm was not, however, tested In a real-world scenarıo. A subsequent effort by thıs group (Scarpazza, Villa, \& Petrını, 2008b) focuses on real-world applicatıons involvıng much larger dıctıonaries, ranging from 6,000 to 20,000 queries. This Implementation of the Aho Corasick 
algorithm achieves a worst-case throughput of $2.5 \mathrm{Gbit} / \mathrm{s}$ using two Cell $\mathrm{B} / \mathrm{E}$ processors. This group has also demonstrated an implementation of the Aho Corasick algorithm which is capable of searching up to 200 queries simultaneously with a throughput of $40 \mathrm{Gbit} / \mathrm{s}$, representing the highest achieved search throughput in Cell B/E string matching literature (Scarpazza, Villa, \& Petrini, 2008a). In addition, this group has explored regular expression matching on the Cell B/E platform (Scarpazza \& Russell, 2009), achieving peak throughputs between $8 \mathrm{Gbit} / \mathrm{s}$ and $14 \mathrm{Gbit} / \mathrm{s}$.

Robert Cameron's Parallel Bitstreams for XML (Parabix) string matching algorithm offers a radically different approach relative to Aho Corasick algorithms (Cameron, Herdy, \& Lin, 2008). This algorithm transposes queries and databases into bitstreams, which can then be searched using bitwise operations. The Parabix algorithm has been implemented on the Cell B/E (Cameron, 2008), however it is not benchmarked in any real-world applications, making comparisons between the Parabix approach and Aho Corasick implementations difficult.

Due to the recent popularization of the CUDA platform for scientific computing on graphics processing units, computer science literature contains several GPU implementations of string matching algorithms. As with string matching on the Cell $B / E$, network intrusion detection and computational biology are leading applications for these algorithms. As a precursor study in GPU string matching, Kouzinopoulos and Margaritis implemented several exact string matching algorithms, including the naive, Boyer-Moore-Horspool, Knuth-Morris-Pratt, and Quick Search algorithms (Kouzinopoulos \& Margaritis, 2009). When searching databases of 20 queries, these algorithms achieve throughputs between $5 \mathrm{Gbit} / \mathrm{s}$ and $15 \mathrm{Gbit} / \mathrm{s}$ using a GTX 280 graphics card. Of these algorithms, the Boyer-Moore-Horspool algorithm achieved the highest throughput. 
Vasılıadıs et al. have developed GNORT, an Aho Corasıck ımplementation for the GPU which is optımızed for network intrusion detection (Vasilıadis, Antonatos, Polychronakıs, Markatos, \& S. Ioannıdıs, 2008). Thıs Implementation is capable of searchıng up to 4000 queries simultaneously with a throughput of $1.5 \mathrm{Gbit} / \mathrm{s}$ using an 8600GT card. Vasılıadıs et al. have also implemented the Boyer-Moore and the Knuth-Morris-Pratt algorithms on the GPU, achieving throughputs of approxımately 1 Gbit/s and $100 \mathrm{Mbit} / \mathrm{s}$ respectively with a 100-query dictionary. These experıments were also performed on a $8600 \mathrm{GT}$ graphıcs card. Thıs group has also made efforts in the area of regular expression matching for network intrusıon detection on GPU (Vasılıadıs, Polychronakıs, Antonatos, Markatos, \& Sotırıs Ioannıdıs, 2009) achıeving throughputs of approxımately $16 \mathrm{Gbit} / \mathrm{s}$ whıle searchıng a dictionary of 20 regular expression queries.

Schatz and Trapnell have produced an implementatıon of the Aho Corasıck algorithm which is tailored to computational biology applicatıons (Schatz \& Trapnell, 2007). Thıs GPU ımplementation has achıeved a speedup of $35 x$ relatıve to an equivalent CPU Implementation, however no absolute measures of performance are offered by the authors. 


\section{Exact String Matching for MS/MS Protein Identification using the Cell Broadband Engine}

\subsection{Introduction}

Thıs chapter detaıls the development of a strıng matchıng algorithm on the Cell $B / E$ architecture for use in the IdMS/MS data analysıs pıpelıne. The algorithm has been designed and implemented with the intention of fulfilling step 3 of the IdMS/MS pipelıne, as seen in Figure 1-8 of section Section 1.2. Thus, the algorithm is taılored toward searchıng short peptıde sequence tags agaınst large static proteomic databases.

Thıs chapter is based on the journal artıcle, "Exact Strıng Matchıng for MS/MS Proteın Identıfication usıng the Cell Broadband Engıne" (Peace et al., 2011).

\subsection{Existing String Searching Algorithms}

As a first step toward building a string matching module for a IdMS/MS system, we have ımplemented and optımızed several state of the art strıng matchıng algorithms on the Cell $B / E$ in order to determıne the suitability of these algorithms for IdMS/MS. We have implemented the shiftıng substring (naive), Boyer-Moore (Boyer \& J. S. Moore, 1977), Rabın-Karp (Karp \& Rabın, 1987), and Parabıx (Cameron, Herdy, \& Lın, 2008) strıng matching algorithms, adaptıng them for the Cell B/E's multıcore architecture and applyıng advanced optımızatıon technıques such as loop unrollıng, applicatıon of SIMD vector operatıons, data parallelısm, and multı-bufferıng technıques. Our ımplementatıons of the Boyer-Moore and Rabın-Karp algorıthms are the first Cell B/E Implementations of these algorithms, to our knowledge. Initial prototypıng and Implementation of these algorithms on the Cell B/E was performed 
as part of a fourth year undergraduate research project, with substantial additional optımızation, recodıng, and performance analysıs performed durıng the master's research period.

\subsection{The Orthogonal Parabix Algorithm}

As described previously, the Parabıx approach to strıng matchıng, as developed by Rob Cameron, is able to improve search times by encoding the search database as a set of bitstreams. While the bitwise encoding scheme of the Parabix algorithm offers a sıgnificant speedup relative to byte encoded alternatives, the Parabıx algorithm was orıginally desıgned for XML parsıng, a domaın in which modifications to the database must be performed onlıne. Any tıme spent transposıng the database into bitstreams results in a decrease in online search performance, and the algorithm is designed around this restraint. Genomic and proteomic databases, on the other hand, are updated only a small number of tımes per year. Preprocessing of these databases may be done offlıne without affecting search performance. With this in mınd, the concept of parallel bitstreams was adapted in order to maxımıze the amount of offlıne pre-processıng done whıle mınımızıng onlıne processıng. The resultıng algorithm, called the orthogonal Parabix algorithm, is theoretically capable of searchıng one word of a database usıng only $2 n-2$ bitwise operations, where $n$ is the length of the query. On a modern computer architecture, a word contains 64 bits, allowing for 64 character locations to be searched in this tıme. Typical peptide query lengths are between 4 and 8 characters, therefore this algorithm is theoretıcally capable of searching over 10 database locations per bitwise operation under typıcal searchıng conditıons. 


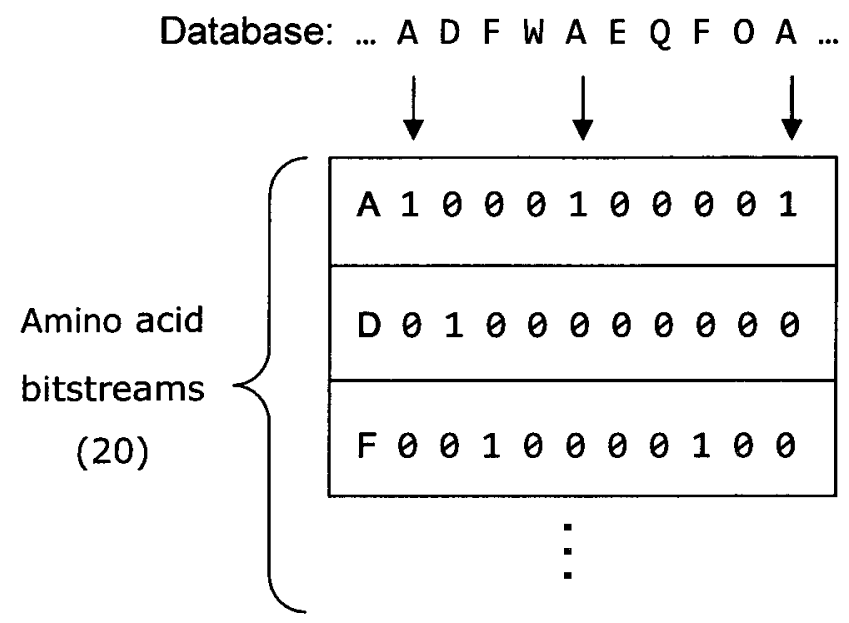

Figure 3-1 - Orthogonal encoding of a database segment into bitstreams $A, D$, and $F$. Red arrows indicate the encoding of " $A$ " amino acids by the first " $A$ " bitstream

The algorithm pre-processes the database into 20 orthogonal bitstreams, each representing a single amino acid. For each bitstream, the $i$ th bit is high if position $i$ in the database is occupied by the amino acid represented by that bitstream. Figure 3-1 demonstrates this orthogonal encoding for amino acid bitstreams $A, D$ and $F$.

An orthogonally encoded database requires 20 bits of storage per location in the database, a $250 \%$ increase relative to an equivalent database using a byte-wise encoding scheme. While significant, this increase in space usage is comparable to an efficient suffix array encoding (Ferreira, Oliveira, \& Figueiredo, 2009).

For a given peptide sequence tag query, only the bitstreams which represent query characters are required to be in memory at runtime. When presented with a query, the orthogonal Parabix algorithm brings into memory the query bitstreams in the order that they appear in the query. Each query bitstream is shifted to the left by $i$ characters, where $i$ is the index of the bitstream character within the query. With the bitstreams shifted in this manner, the bitstreams will all contain the value 1 at a position $n$ iff the complete query is present starting at position $n$. Therefore, ANDing 
the shifted bitstreams will produce an output bitstream which contains a 1 at all

$$
\text { Database: ...VCVARNDA... }
$$

Step 1: SHIFT bitstreams

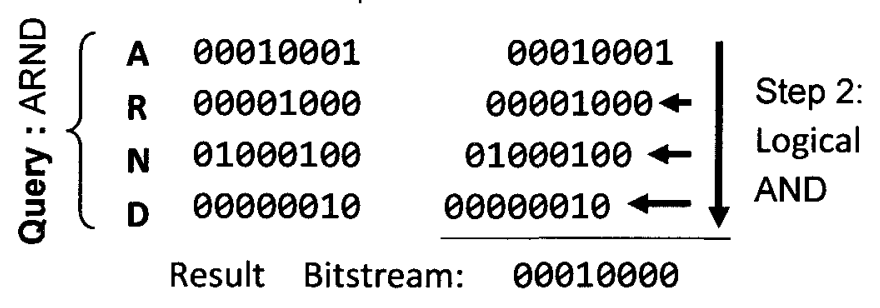

Figure 3-2 - Online Shift-AND procedure for query "ARND" in database containing "...QWVARNDA...". Bitstreams $A, R, N$ and $D$ are fetched into memory in the order that they appear in the query.

positions where the query is present in the database. Figure 3-2 demonstrates the online SHIFT and AND procedure for the query ARND.

The total number of SHIFT operations required during the online procedure is $n-1$, and the total number of AND operations is also $n-1$, where $n$ is the length of the query. Thus, for each word in the database, $2 n-2$ bitwise operations are needed.

\subsection{Results}

In order to determine the optimal string matching algorithm for hdMS/MS, optimized Cell B/E implementations of all previously detailed string matching algorithms were applied to a sample proteomic database containing a subset of the human proteome and the resulting search times were compared. Each of the tests were performed on a QS22 Cell B/E BladeCenter server with two PowerXCell $8 \mathbf{i}$ processors and 32 GB of RAM. Only one processor, totalling 8 SPEs, was used during our experiments because all algorithms were designed and tested on a simulated Cell system which contained 8 SPEs. The naive string matching algorithm appears twice in these results - with 
and without the use of SIMD vector operations - in order to demonstrate the increase in performance achieved through optimization on the Cell $B / E$.

Figure 3-3 demonstrates that each of the algorithms, as implemented, scale linearly with proteome size. In addition, Figure 3-3 demonstrates that the Orthogonal Parabix algorithm is extremely well-suited to the exact string matching problem which idMS/MS presents - its runtime line is indistinguishable from the $x$-axis for most file sizes. When searching a $256 \mathrm{Mb}$ input file for a query of length four, the orthogonal Parabix approach achieves a sustained throughput of $215.4 \mathrm{Gbps}$, representing a speedup of $19.6 x$ over the Parabix approach and a speedup of $124.0 x$ over a naive string searching implementation.

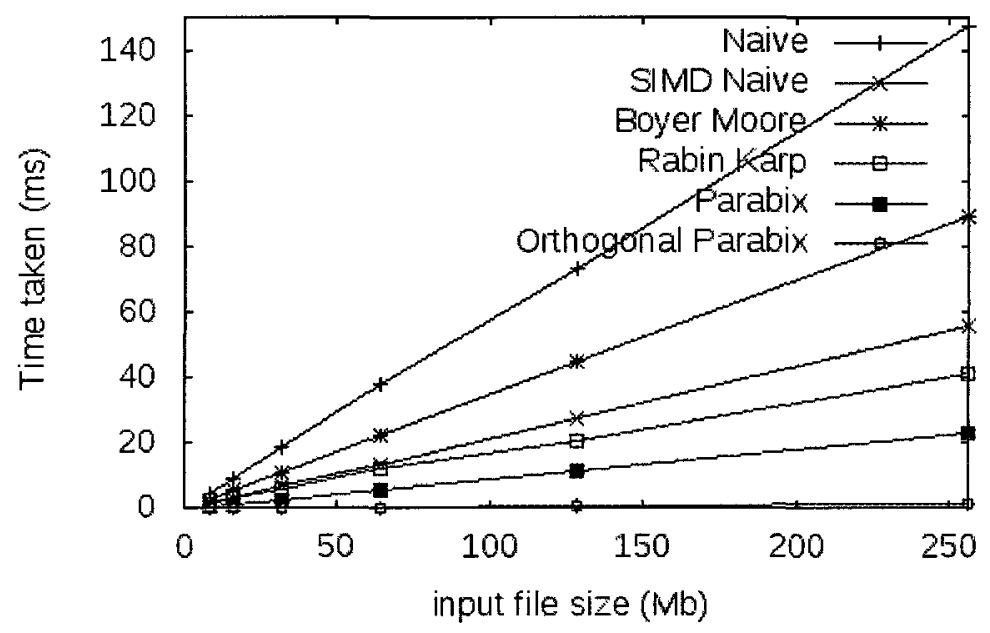

Figure 3-3 - Search times under varying database size

Figure 3-4 demonstrates the speedup which is obtained when data parallelism is employed to distribute the database searching task concurrently among multiple SPEs (256Mb database, 4 character query). For all algorithms, the speedup for $n$ SPEs is approximately linear. By extension, the Orthogonal Parabix algorithm retains its speedup over other algorithms regardless of the number of SPEs used. 


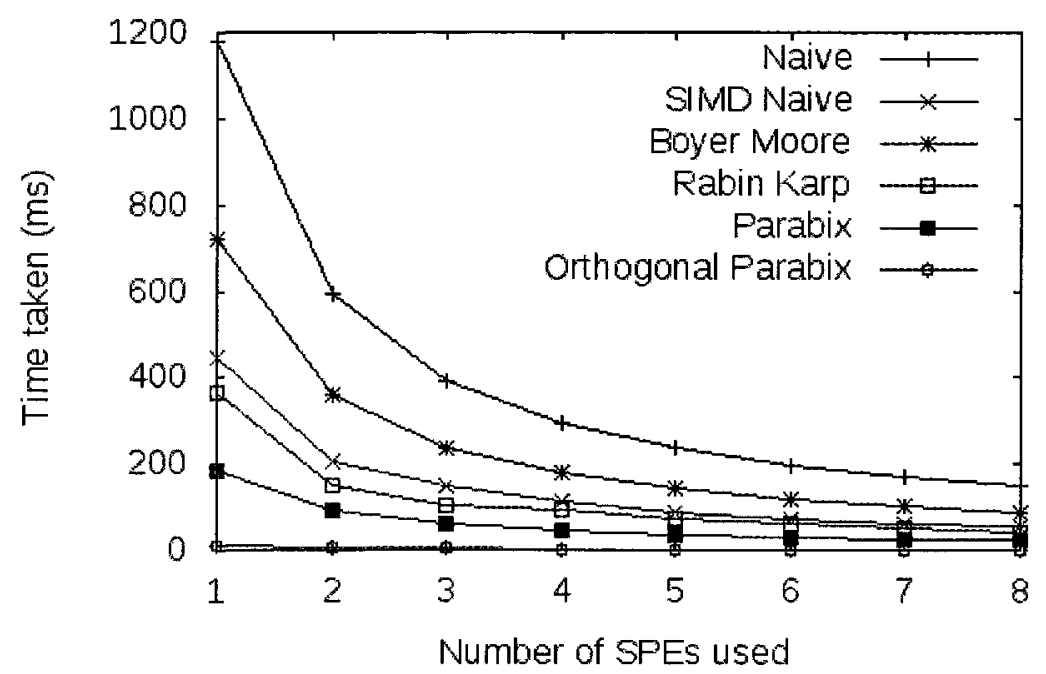

Figure 3-4 - Search times under varying SPE usage

\subsection{Conclusions}

We have successfully implemented, optimized and benchmarked several single exact string matching algorithms on the Cell $B / E$ hardware. While these implementations of existing string searches performed well on the hardware, the highly specialized searches required by idMS/MS present an opportunity for a more tailored approach to string searching. In response to this opportunity, we have created an extension of the Parabix approach - called the orthogonal Parabix approach - which is ideal for the string searching problem presented by hdMS/MS.

Running on a Cell $\mathrm{B} / \mathrm{E}$ blade server, the Orthogonal Parabix string matching approach was able to achieve a sustained search throughput of 215.4 Gbps under typical peptide fragment search parameters - a speedup of $124 x$ relative to general purpose string searching algorithms. Considering that the size of the human proteome is roughly $0.6 \mathrm{~Gb}$ and a typical mass spectrometer obtains one sample per second, this throughput suggests that the orthogonal Parabix approach running on the Cell $\mathrm{B} / \mathrm{E}$ hardware is capable of searching proteomic databases within the realtime deadlines imposed by idMS/MS. However, subsequent research (see the 
proceeding chapter) has demonstrated that GPU hardware is even better suited to parallel data analysis tasks involving large proteomic or genomic databases; as a result, we have concluded that further parallelization of idMS/MS data analysis would be pursued on the GPU platform which produces yet another significant speedup relative to the Cell $B / E$ platform. 


\section{Six-Frame Genomic String Matching for Peptide Sequence Tags using the CUDA Platform}

\subsection{Introduction}

This chapter describes the CUDA platform Implementation of the orthogonal Parabıx string searchıng algorithm. This algorithm fulfils the requirements of peptide sequence tag searchıng for IdMS/MS, as highlıghted in step 3 of Figure 1-8 in section 1.2. In addition to the implementation of the orthogonal Parabix algorithm on the GPU platform, the algorithm was improved sıgnificantly relatıve to the previous Cell $B / E$ ımplementatıon. These Improvements include the abılity to search genomic in addition to proteomic databases, and improved handling of ambiguitıes which arise from de novo sequencing of product ion spectra. The throughput of the orthogonal Parabıx algorithm is also improved by an order of magnitude relative to the Cell $B / E$ Implementation. Finally, the GPU platform will receive future support and new GPU hardware is developed regularly.

\subsection{Adapting Orthogonal Parabix to Genomic Databases}

In order to search a query peptıde fragment agaınst all proteıns encoded by a species' genome, rather than the subset of proteins which have been previously discovered and annotated, it is imperative that our search algorithm be able to search DNA databases in all sıx readıng frames (ı.e. all 6 possıble interpretations of the DNA sequence by the translation and transcription proteın synthesis machınery withın a cell). 
The pre-processing steps of the orthogonal Parabix algorithm are capable of adapting from proteomic databases to six-frame genomic databases without impacting the online search throughput of the algorithm. The pre-processing of genomic databases is accomplished through a process which converts the genomic database into two sets of three interleaved proteomic databases in such a way that the three proteomic databases in each set can be searched using the SHIFT and AND procedure described above with no additional overhead.

The process begins by constructing the genetic complement of a given genomic database, then reversing this genetic complement database front to back. The original genomic database represents three of the reading frames for the genome, while the newly-built genetic reverse complement database represents the previously-unseen reading frames and is stored in a manner identical to the original genomic database.

Once the database representing the genetic reverse complement has been built, in silico translation and transcription are performed on all six frames of the genome.

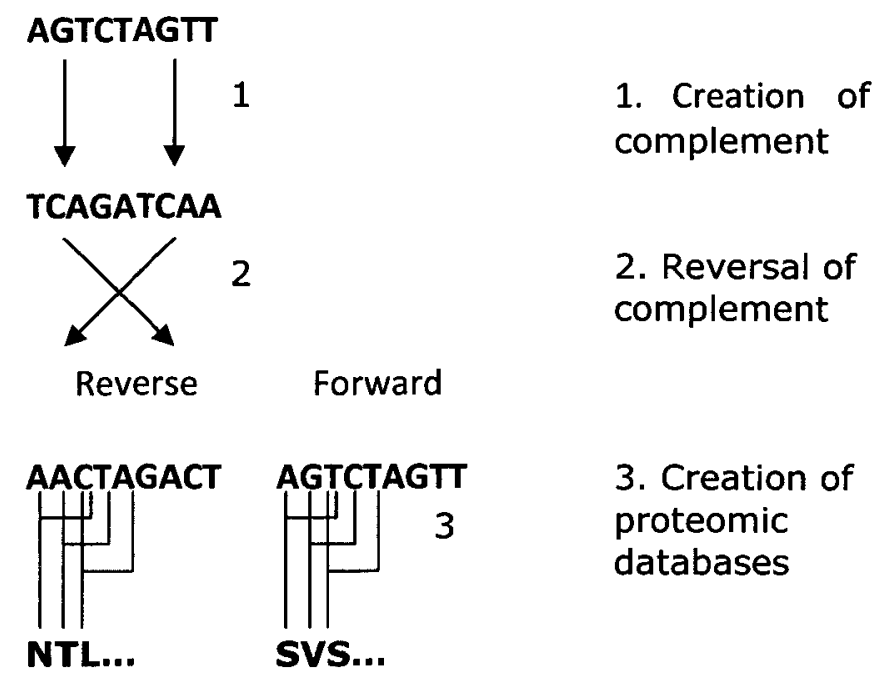

Figure 4-1 - Converting a genomic database into a proteomic database 
This in silico translation and transcription is performed in each location of the original and complemented databases, creating two proteomic databases for which the amino acid at location $n$ of the proteomic database resulting from reading frame $i$ is the result of the translation and transcription of the codon at the corresponding location in the corresponding genetic database. Figure 4-1 demonstrates the three steps used to convert a genomic database into proteomic databases. In this figure, each of the three colours red, blue and green correspond to the three reading frames present in the genomic database.

The proteomic databases are then converted into orthogonal bitstreams in the manner described in the previous section. These steps can all be performed during database pre-processing. At this point, the six reading frames could be separated into six databases, however this de-interleaving step is not necessary as the online orthogonal Parabix algorithm can search the interleaved database with no effect on performance relative to a database of proteomic origin which contains the same amount of amino acids. Thus, the database remains interleaved in order to reduce pre-processing requirements.

During the online portion of the algorithm, the amount which each bitstream is shifted is increased by a factor of three so that amino acids within the same reading frame are aligned with each other during the SHIFT and AND procedure. Increasing the shift length on each bitstream does not increase the computation time for a given query; the series of operations required for searching are identical for proteomic and genomic databases. No additional memory transfers are required relative to a database of the same size for which bitstreams are shifted by only one bit. Therefore, no searching overhead is introduced when bitstreams are built from genomic rather than proteomic databases. 


\subsection{GPU Implementation Details}

In the GPU implementation of the orthogonal Parabix algorithm, an orthogonally encoded database is loaded from file into GPU global memory as an array of bitstreams so that all bitstreams are available in GPU memory prior to the determination of a query. In addition, an output bitstream of length equal to the database length is created in GPU global memory. All bits of the output bitstream are initialized to 0 . GPU memory size represents a limitation on the size of the genomic database which can be searched at one time, however this limitation is not relevant when genomic databases are limited to genes which are protein-encoding. $1 G B$ is a typical mid-range GPU memory size; using the previously-described encoding scheme, approximately $4 \times 10^{8}$ amino acids can be stored in GPU memory, which corresponds to a genomic database containing $2 \times 10^{8}$ base pairs. The human genome contains $2.91 \times 10^{9}$ base pairs, however only $1.1 \%$ of these base pairs could potentially encode proteins (Venter et al., 2001). All possible proteins encoded by the human genome, then, can be represented by $3.2 \times 10^{7}$ base pairs. This is well within the limits of any CUDA-capable GPU.

Once the host receives a query, this query is converted by the CPU into a query code - an array of integers, where the $i$ th position of the array contains the bitstream index of the ith amino acid of the query sequence tag. That is, the integer at querycode[ $i]$ is the index of bitstream $m$ in the array of bitstreams iff the query at $i$ is represented by amino acid $m$. This query code is then transferred to the GPU global memory. This encoding of the query allows for direct indexing into the array of amino acid bitstreams, reducing overhead during searching. 
Once data has been set up on the GPU's global memory, $\lceil n / w\rceil$ GPU kernel threads are launched by the host device, where $n$ is the number of amino acid locations in each proteomic bitstream and $w$ is the word size in bits (typically 64). Each of these kernel threads performs the SHIFT and AND series of operations on a single word of the bitstreams relating to the query. No data is moved explicitly into GPU shared memory by the kernel functions; optimal performance is achieved when the input and output bitstreams and the query are all stored in GPU global memory. In addition, using texture pipelines to access global memory does not increase search throughput. Figure 4-2 demonstrates the features of the CUDA memory hierarchy which were explored during implementation of the orthogonal Parabix algorithm.

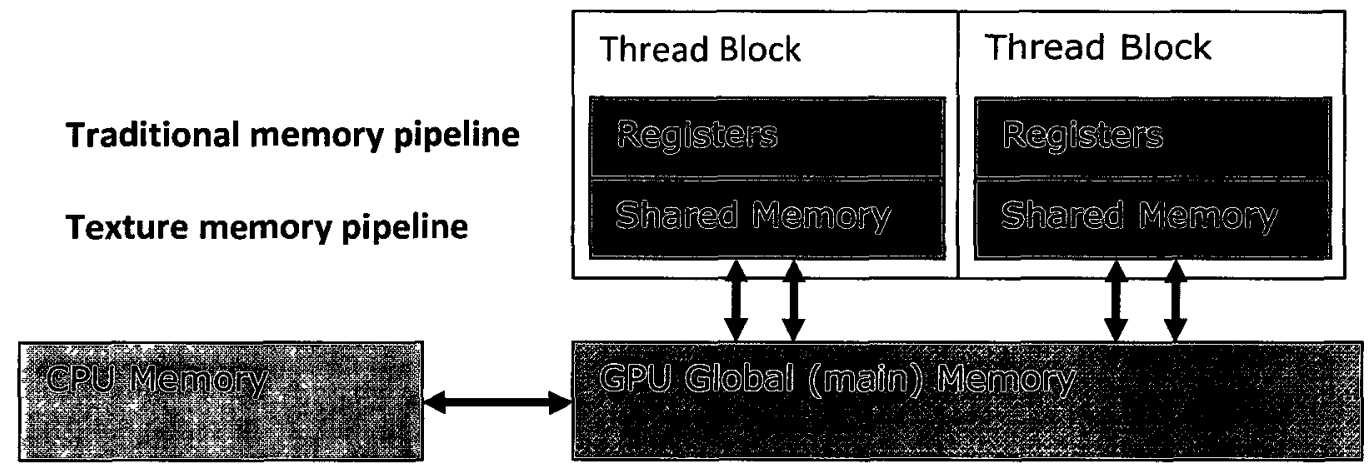

Figure 4-2 - CUDA memory hierarchy. Performance is optimal when all data is stored in GPU global memory and the traditional memory pipeline is used.

Unfortunately, byte-addressable memory does not allow for the exact SHIFT and AND procedure as described previously. For query hits which straddle the boundaries of addressable memory, bitstreams for terminal amino acids in the query cannot be shifted leftward in order to align with the first amino acid in the query using the previously described SHIFT and AND procedure. For example, the query "ARND" which appears in consecutive words "VVVVVAR" and "NDVWVVVV", the amino acids $\mathrm{N}$ and $\mathrm{D}$ cannot be aligned with the amino acids $\mathrm{A}$ and $\mathrm{R}$ using a simple leftward shift. Therefore, a more complex SHIFT and AND procedure was developed for the GPU kernel. For a query of length $N$, in order to search each position of word $i$ of the 
database, words $i$ and $i+1$ are accessed in global memory for bitstreams relating to characters 2 through $\mathrm{N}$ of the query. The online SHIFT and AND procedure is then performed on the word tuples; when searching databases which are genetic in origin, word $i$ of query character $n$ is shifted to the left by $3 n$, while word $i+1$ is shifted to the right by (word size $-3 n$ ). When searching databases which are proteomic in origin, word $i$ of query character $n$ is shifted to the left by $n$ while word $i+1$ is shifted to the right by (word size $-n$ ). All shifts are unsigned. Once shifted, the words at $i$ and $i+1$ are then ORed together, producing a single word which can be ANDed with other bitstreams in the manner defined in the original SHIFT and AND procedure in order to produce a result bitstream. Figure 4-3 demonstrates the modification to the SHIFT and AND procedure which allows the GPU kernel to operate using word-

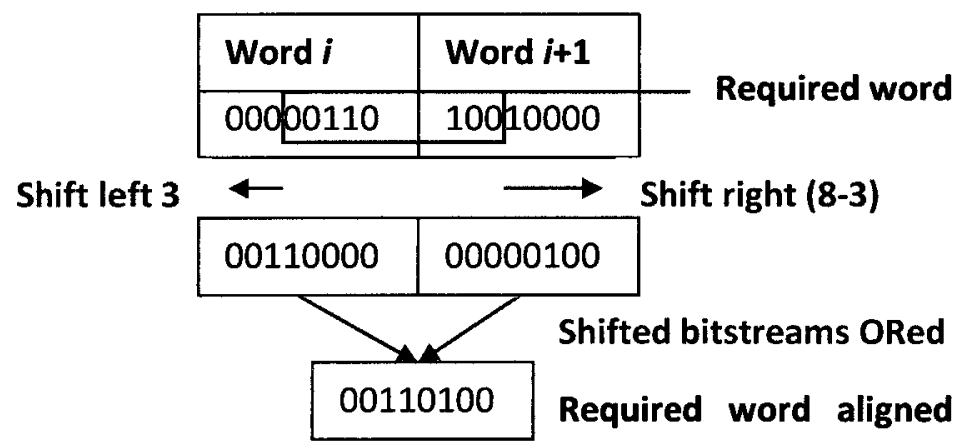

Figure 4-3 - Modification to SHIFT and AND procedure for handling byte-addressable memory on GPU

addressable memory. In this figure, 8-bit words are used for illustrative purposes, and the required word must be shifted to the left by 3 bits.

Initial implementations of the orthogonal Parabix algorithm on GPU wrote the output bitstream directly to global memory, then copied this bitstream from global memory to the CPU memory. This series of memory operations was costly, however, and profiling of this code showed that the real-time portion of the algorithm was memory-bound, as can be seen in Figure $4-4 ; 77 \%$ of the GPU run time of the 
algorithm was spent transferring the output stream from GPU global memory to CPU memory, which appears in Figure 4-4 as memcpyDtoH (memory copy, device to host). For the purposes of peptide sequence tag searches, however, the level of precision provided by this complete output stream is not required. Knowing the location of the result to within one word is sufficient so long as this approximate location can be used to uniquely identify the protein in which the peptide sequence tag has been found. With this in mind, the output of the algorithm was modified such that the resultıng bitstream was compressed by a factor of one word - each bit in the output bitstream represents the presence or absence of one or more search hits in one word of locations in the database. A second pass of the output bitstream can be performed on the host in order to determıne the precise location of a match once all of the approximate matches have been returned. For a word size of 64 bits, then, the amount of data transferred from GPU global memory to CPU global memory is reduced by a factor of 64 . This optimization is well suited to the GPU implementation of the orthogonal Parabıx algorithm. Each kernel deals with one word of the database bitstreams, therefore each kernel is responsible for writıng a single bit to the output stream as opposed to an entıre word. In order to ensure that each result is unıquely mapped to a proteın, the orthogonal bitstreams are bult during pre-processıng such that each protein is zero-padded to the nearest word boundary. For a typical database, the increase in database size caused by this zero padding is between $3 \%$ and $7 \%$. With thıs optımızation in place, the orthogonal Parabıx algorithm becomes compute bound, with almost $93 \%$ of the GPU run time dedicated to computation. Thıs optımızation then has the dual effect of Increasıng the search throughput significantly and of allowing the algorithm to scale more successfully with GPU hardware performance as more processing power is introduced in future hardware releases. The move from memory-bound to compute-bound processing can be seen In Figure 4-4. 


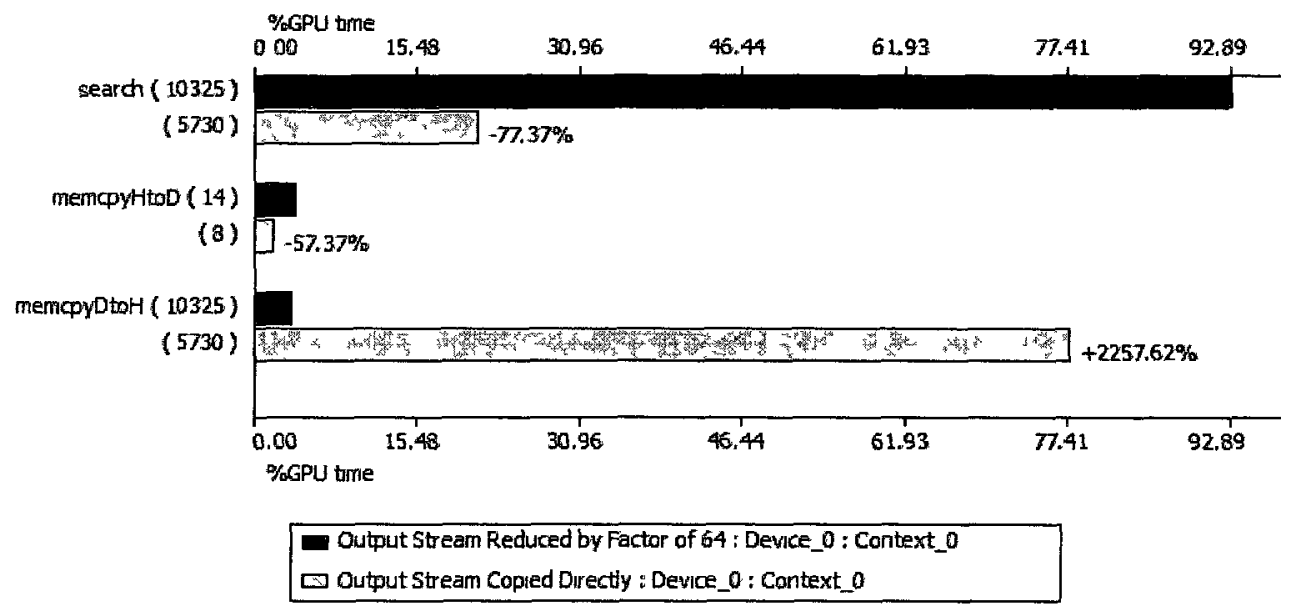

Figure 4-4 - Comparison of relative time spent on compute vs. memory operations before and after optimization of memory transfers. Green bars represent postoptimization numbers. "search" represents computation time, while "memcpyHtoD" and memcpyDtoH" represent time spent on memory transfers between host and device

\subsection{Handling Ambiguity in Peptide Sequence Tags}

Because of the nature of MS/MS spectra and the de novo process, peptide sequence tags often contain ambiguities which must be accounted for when these tags are searched against a database. The GPU implementation of the orthogonal Parabix algorithm has been adapted in order to handle typical forms of ambiguity with a minimum of false positives, expanding the number of valid queries which the algorithm can accept.

The first common form of ambiguous query is an order-ambiguous query in which two amino acids are known to be adjacent to one another at a certain position of the query but their relative positions are unknown - for example, a query could be ARSD or ASRD. This class of query is caused by the absence of a single peak in a spectrum; the resulting de novo sequencing determines that the distance between two peaks 
corresponds to a unique pair of amino acids without knowing the amino acids' order within that pair.

This class of query can be represented by a series of bitwise operations which are based on the SHIFT and AND series of operations. Given an order-ambiguous query with characters $\mathrm{R}$ and $\mathrm{S}$ which occupy query positions $i$ and $i+1$ in an unknown order, the modified search kernel performs the standard SHIFT and AND operations for all positions in the query except $i$ and $i+1$. For positions $i$ and $i+1$, the modified kernel implements the following bitwise procedure:

$$
[(R \ll i) \&(S \ll i+1)] \mid[(R \ll i+1) \&(S \ll i)]
$$

In this procedure, a bitstream for the sequence "RS" and a bitstream for the sequence "SR" are created independently. These bitstreams are then joined using an OR operation, resulting in a bitstream for which a 1 is present iff either "RS" or "SR" is present.

The second case of query ambiguity which is handled explicitly by a modification to the orthogonal Parabix algorithm is a query with an isobaric subsequence. Because the masses of certain amino acid sequences - such as GG and $K$ - are indistinguishable when using most mass spectrometers, de novo sequencing often produces motifs in which two or more short sequences could be present at a specific location.

The orthogonal Parabix framework does not allow for a single query to represent both the GG and $K$ motifs, due to the rigid structure of the SHIFT and AND procedure; any amino acids which occur downstream of the GG / K subsequence must be shifted to the left by a different amount depending on the presence of the GG or $\mathrm{K}$ 
subsequence, and the SHIFT and AND procedure does not allow this flexibility. As a result, a query with GG / K ambiguity is launched as two separate queries, one of the form $a \mathrm{GG} b$ and one of the form $a k b$. Launching two queries represents a significant decrease in performance relative to an unambiguous query - a slowdown of approximately $1.6 \mathrm{x}$ - however in this worst-case scenario the orthogonal Parabix algorithm is still preferable to alternative string searching methods.

\subsection{Results}

All GPU and serial experiments detailed in this section were performed on the following hardware:

- Serial System: Intel Core 17920 processor at $2.67 \mathrm{GHz}$

- $12 \mathrm{~GB}$ triple channel DDR3 memory at $523 \mathrm{MHz}$

- GTX260 System: NVIDIA GeForce GTX 260 graphics card

- 192 CUDA cores

- $896 \mathrm{MB}$ global memory

- $576 \mathrm{MHz}$ core frequency

- $999 \mathrm{MHz}$ memory frequency

- GTX570 System: NVIDIA GeForce GTX 570 graphics card

- 480 CUDA cores

- $1280 \mathrm{MB}$ global memory

- $742 \mathrm{MHz}$ core frequency

- $1900 \mathrm{MHz}$ memory frequency

Each of the experiments wherein the database size is fixed was performed with a database size of $512 \mathrm{Mb}$. This database size is comparable to the subsection of the human genome which is capable of encoding proteins, which is itself approximately $512 \mathrm{Mb}$.

Typical peptide sequence tag lengths are in the range of 4 to 6 characters, with peptide sequence tags of length 7 to 8 characters occurring infrequently. Therefore, all experiments focussed on queries of length 4 through 8 . 
For each data point, the GPU search kernel was launched 1000 times using a single pre-determined query, and the average search time of the 1000 runs was recorded. Similarly, for serial implementation data points, the online portion of the algorithm was run 1000 times and the average search time was recorded. Orthogonal Parabix performance is independent of the query composition, that is, any query of length $n$ with ambiguities in the same locations will produce the same results regardless of the amino acids present in the query.

Timing for kernel code was performed using the cudaEvent data type, and timing for serial code was performed using the time() command. The resolution of the cudaEvent method of timing is equivalent to the period of the GPU. The time() command's resolution is one second, however this low-resolution timing method combined with the number of runs performed is sufficient in order to provide a baseline by which the speedup of the parallel algorithm can be measured. Both the cudaEvent timing model and the time() command record wall times, therefore the OS or other processes may have affected the results of these experiments. All GPU and serial code was compiled using Microsoft v90 compiler and the Nvidia CUDA Toolkit version 3.2 and run on the Windows 7 platform. 


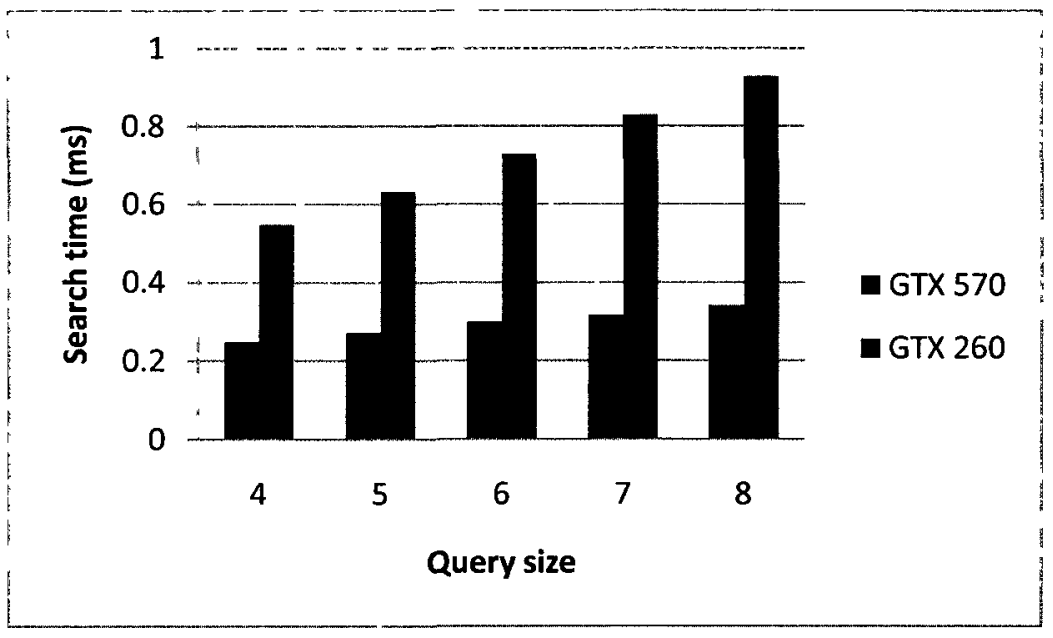

Figure 4-5 - Effect of query size on search times on GPUs. Serial search times are not present in order to highlight the comparison between GPU data points.

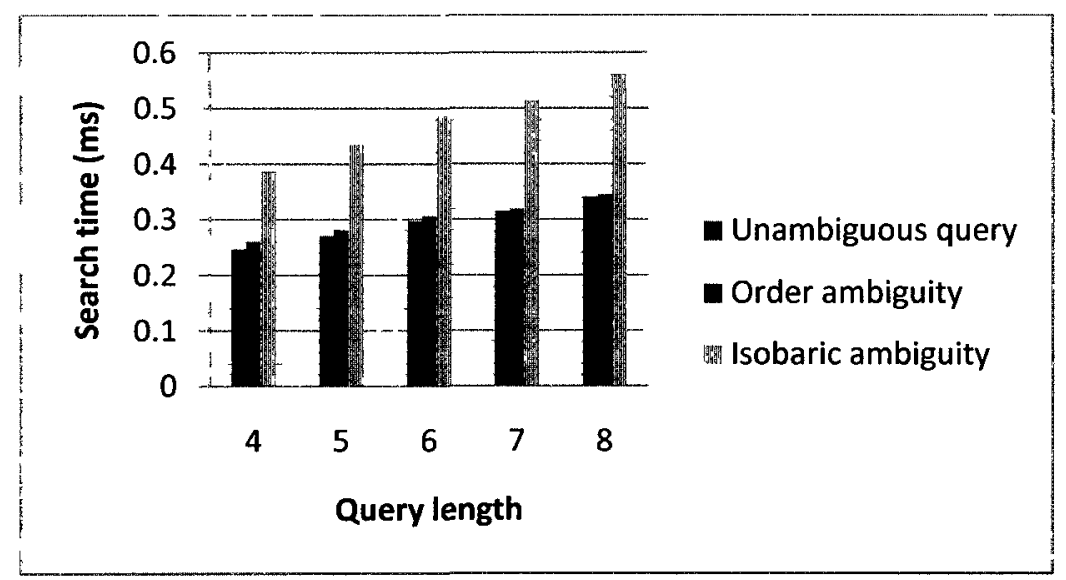

Figure 4-6 - Effect of ambiguous queries on search times. Experiment performed on GTX 570 graphics card.

Figure 4-5 and Figure 4-6 demonstrate the effect of query length and complexity on search times for the orthogonal Parabix algorithm. Increase in query size causes a linear increase in search times. Order ambiguity, which is handled using a modification to the online search algorithm, causes a small fixed increase in search times. This matches the expectations for this modification to the search algorithm. Isobaric ambiguity increases search times by a fixed percentage which is approximately $60 \%$ of an unambiguous query search. Total search time is not doubled in the case of the $\mathrm{GG} / \mathrm{K}$ ambiguity because only one result is transferred 
from GPU global memory to CPU memory. In the worst case scenario - a query of length 8 with a GG/K class of ambiguity - the GTX 570 sustains a throughput of 911.4 Gbps, which is well within reasonable bounds for the purposes of informationdriven MS/MS and preferable to a similar unambiguous search throughputs using other searching algorithms.

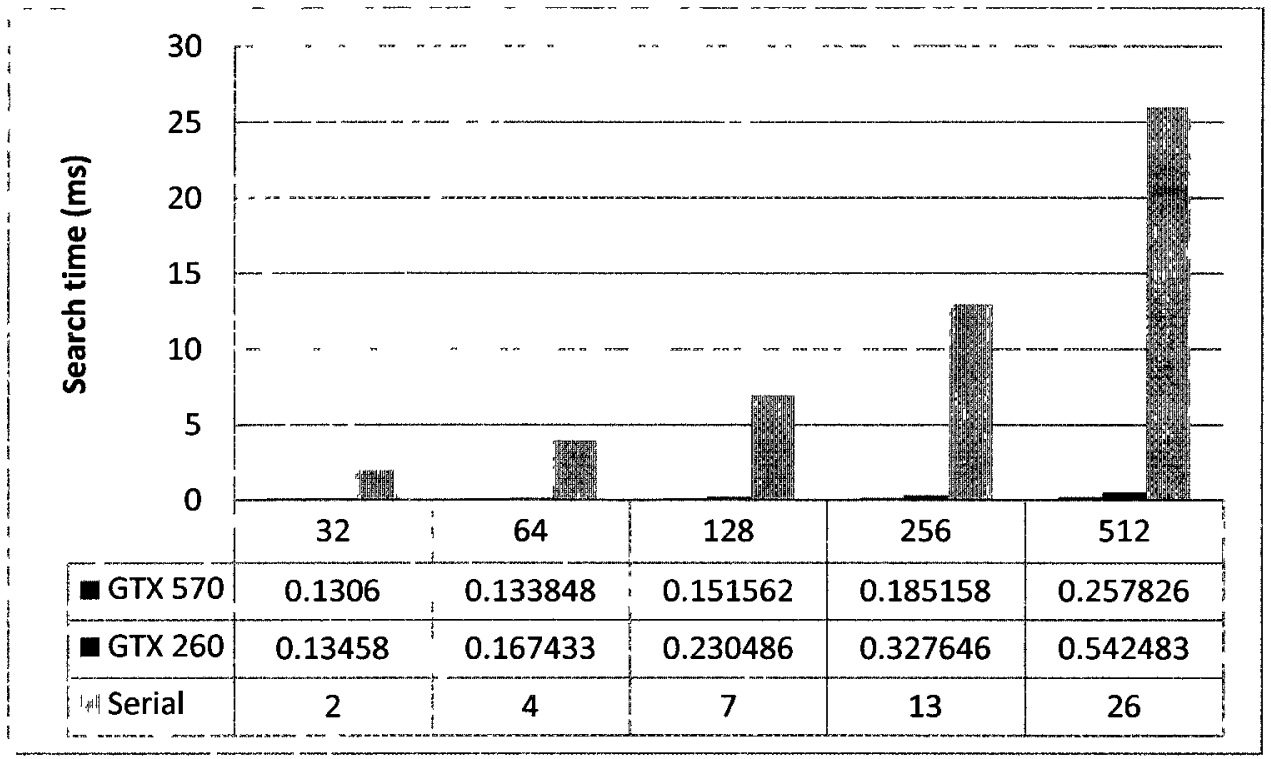

Figure 4-7 - Comparison of GPU and CPU search times over varying database sizes.

Figure 4-7 demonstrates the speedup achieved when comparing the GPU implementation of the orthogonal Parabix approach with an equivalent serial implementation which takes advantage of the memory output optimization described in section 4.3. When searching a genomic database of length $512 \mathrm{Mb}$, the serial implementation of the orthogonal Parabix algorithm produces a search throughput of 19.7 Gbit/s. The GPU implementation on a GTX 260 graphics card produces a search throughput of $943.8 \mathrm{Gbit} / \mathrm{s}$, providing a $48 \mathrm{x}$ speedup over the serial implementation. The GTX 570 graphics card, meanwhile, produces a search throughput of 2066.4 Gbit/s - a speedup of $104 x$ over the serial implementation. When compared to 
general purpose string matching algorithms as implemented on GPU, the orthogonal Parabix produces a $40 \mathrm{x}$ speedup over both Boyer-Moore and Aho-Corasick based approaches as demonstrated by (Vasiliadis, Antonatos, Polychronakis, Markatos, \& S. Ioannidis, 2008); this result takes into account the relative compute performance of the graphics cards used, as determined by Nvidia.

\subsection{Conclusions}

The results presented in the previous section demonstrate that the GPU platform is well-suited to the development of a information-driven MS/MS system. This platform provides a vastly superior peptide search throughput relative to equivalent Cell $B / E$ and Intel Core i7 implementations. When searching a genome of comparable length to the human genome under typical peptide search parameters, the GPGPU implementation of the orthogonal Parabix algorithm was able to achieve a sustained throughput of 2066.4 Gbit/s on a NVIDIA GeForce GTX 570 graphics card and 943.8 Gbit/s on a NVIDIA GeForce GTX 260 graphics card. Under comparable circumstances, our Cell B/E implementation sustains $219.3 \mathrm{Gbit} / \mathrm{s}$ and a serial implementation sustains only $19.7 \mathrm{Gbit} / \mathrm{s}$ on the Intel Core i7 processor. Relative to general string searching methods implemented on the GPU, the orthogonal Parabix approach produces a speedup of approximately 40x (Vasiliadis, Antonatos, Polychronakis, Markatos, \& S. Ioannidis, 2008). Taking these results into account, we believe that the GPU platform is the ideal candidate for the parallelization of information-driven MS/MS analysis, and that the orthogonal Parabix string matching algorithm, as implemented, is an ideal string matching algorithm for the purposes of information-driven MS/MS. 


\section{On-line Retention Time / Experiment Time Mapping for Experimental Mass Spectrometry Data}

\subsection{Introduction}

This chapter detals the creatıon of an algorithm which maps the current experıment wall tıme of a LC-MS/MS experıment to the expected peptıde retention time of the experiment. This algorithm is capable of performing this mapping in real-tıme, and thus estımates the current retentıon tıme of an experıment as the experıment proceeds. The algorithm uses data which is avaılable to any real-tıme MS/MS data analysıs system via the mass spectrometer. This retention time / experiment time mappıng algorithm is a vital part of the idMS/MS pıpelıne, as it informs the IdMS/MS system of which peptıdes are lıkely to elute durıng current and upcomıng survey scans, increasing the IdMS/MS system's ability to determine the likelihood that a survey scan peak matches a peptide which has been deemed 'important' and the system's abılity to select peptıdes based on the knowledge of whıch peptıdes will stıll be avallable to the mass spectrometer in future iterations. This algorithm is also useful for directed LC-MS/MS experıments which are interested in specific peptıdes, as the algorithm allows these experiments to locate peptides temporally without a prior knowledge of the experıment LC gradient. Because no LC gradient information is required as input to this algorithm, the algorithm is resilient to errors which could arıse from miscalıbration or loss of calıbratıon of LC ınstruments.

As a step toward the creatıon of the retention tıme / experıment tıme mappıng algorithm, we have developed a novel ANN architecture which is able to accurately predict the retention time of peptides using a limited set of peptide sequence inputs. 


\subsection{Overview of Online Retention Time / Experiment Time Mapping Module}

Figure 5-1 demonstrates the process flow diagram surrounding the online retention time / experiment time mapping module, detailing its interaction with the system as a whole. Note that the inputs and outputs of this module do not relate to the peptide sequence tag matching module described in chapters 3 and 4 , as can be seen in section 1.2 of this thesis.

Prior to the experiment, the module requires the input of a proteome database file containing the amino acid sequence of all proteins which could possibly be present in the sample. Optionally, a genomic database file can be used instead; this DNA sequence file would require in silico 6-frame translation as described in the previous chapter. The sequence database file is parsed offline; all proteins undergo in silico tryptic digestion in order to produce a list of expected peptides for the experiment. The tryptic digestion step accounts for the possibility of a single missed cleavage at all cleavage sites. This is labelled as step 1 in Figure 5-1. The mass and predicted retention time are calculated for each peptide, as seen in step 2 of Figure 5-1, resulting in a database of mass/time points which each correspond to a unique peptide from the fasta database file. This AMT database is queried by the retention time / experiment time mapping module during the experiment at each iteration of the algorithm.

The module receives two inputs during its real-time operation: a list of masses which are currently inside the mass spectrometer with accompanying intensity values and charge states, and the experiment time (in seconds) at which these masses were recorded. Low intensity masses are removed from the mass list because they are 
likely to be statistical noise, and masses with related charges which are not $2+$ or $3+$ are removed from the mass list because ions outside of this charge range are unlikely to be peptides.

The output of the module is a single real value in the range of 0 to 1 . This value represents the retention time which best matches the experimental data which has been recorded by the instrument. This value will be used by the idMS/MS system in order to predict the presence of important peptides in the mass spectrometer, and as a factor in the peptide-importance scoring module.

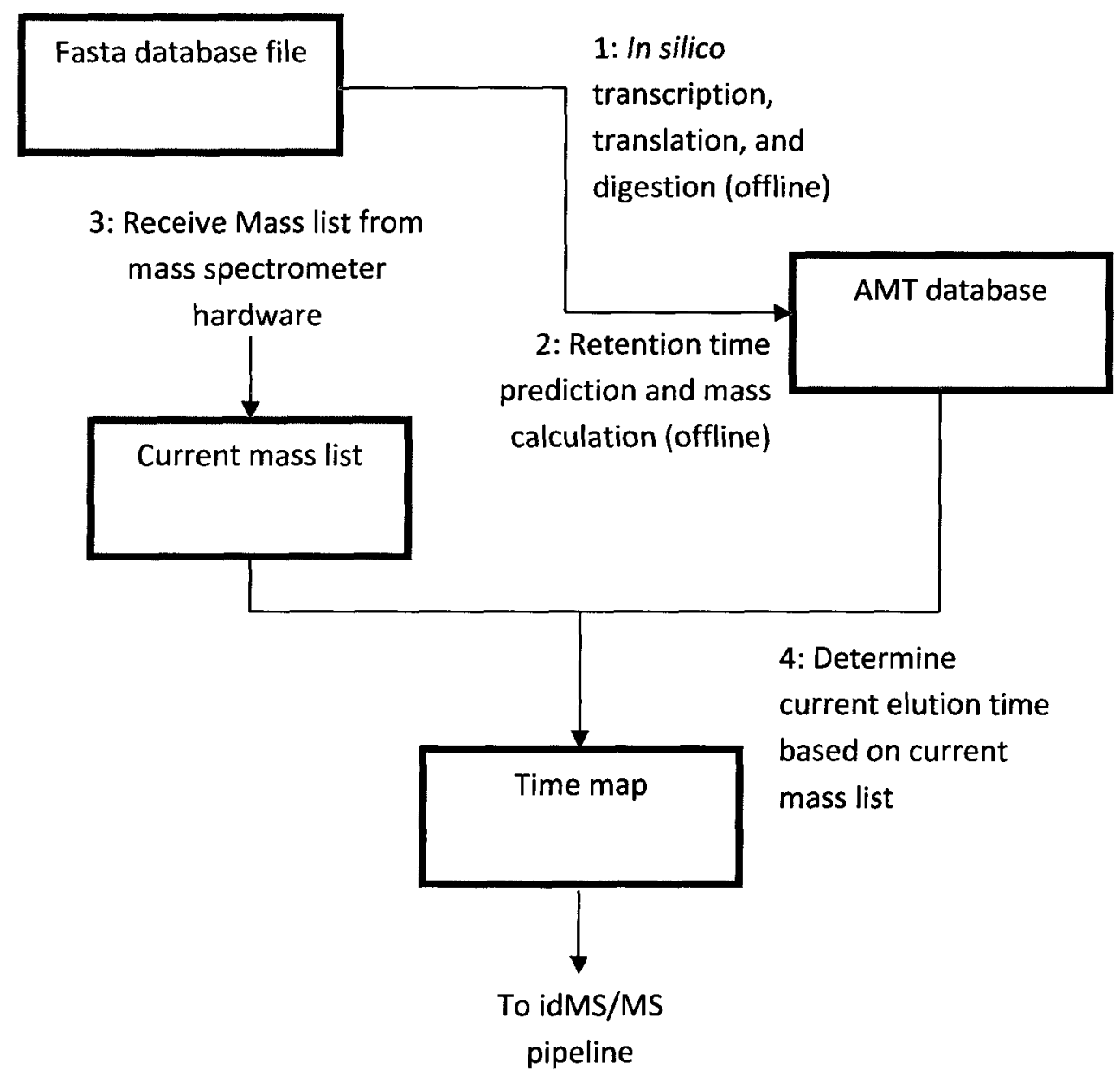

Figure 5-1 - Process flow diagram surrounding the retention time / experiment time mapping module 


\subsection{Peptide Retention Time Prediction}

Retention time prediction is a machine learning problem which aims to predict the chromatographic conditions at which a specific peptide will elute during a LC-MS/MS experiment. All inputs to the retention time prediction model must be derived from the sequence of the protein as provided by the fasta database file.

\subsubsection{Choosing a Linear Regression Technique for Retention Time Prediction}

As seen in section 2.3, retention time prediction literature defines two major approaches to retention time prediction: support vector regression techniques using inputs based on quantitive structure-retention relationship, and artificial neural network techniques using peptide structure information as inputs. The two techniques differ largely with respect to the training sets which they employ; SVRbased retention time prediction techniques have been optimized for training on small, instrument-specific training sets while ANN-based retention time prediction techniques have been optimized for training on large data sets which are built from many experimental data points across varying instruments. The retention time prediction model used for the retention time / experiment time mapping module must be applicable for a variety of instruments. In addition, a retention time prediction module which is not instrument-specific removes the requirement that the system be trained on an instrument-specific data set, removing the need for user input; the ability of the system to perform its function without user input is one of the key features of the retention time / experiment mapping module. Petritis et al. have made available a data set of over 383,000 peptide sequences with retention 
tıme values for the purpose of traınıng and testıng retentıon tıme prediction approaches, makıng large-scale non-specific retention tıme predıction a more attractive option. For these reasons, we have decided to implement an ANN model usıng peptıde sequence information.

\subsubsection{Implementation of existing ANN models}

The current state of the art for retention time prediction using ANNs is a structure developed by Petritis et al. using 1052 inputs, 1050 of which orthogonally encode the sequence of the peptide. Detalls of the orthogonal encoding can be found at (Petritis et al., 2006). The two remaınıng inputs represent the sequence length and the hydrophobıc moment (defined below) of the peptıde. Because Petritıs et al. do not provide a trained ANN model, we have attempted to produce a model using the popular Fast Artıficial Neural Network (http://leenissen.dk/fann/wp/) and Annie (annie.sourceforge.net/) libraries. However, because of the large number of inputs combıned with the large number of traınıng instances, these librarıes were not able to successfully traın a model under MS Windows memory lımitations. Attempts were made to traın the 1052-ınput model usıng recompıled versıons of these libraries which circumvent MS Windows memory lımitatıons; however these models falled to generalıze to non-traınıng points. Thus, we have decıded to develop a novel ANN model usıng a lower number of inputs.

\subsubsection{Producing a novel ANN architecture}

In order to produce an optımal ANN architecture using a small number of inputs, we have tested the inclusion of several popular ANN inputs into a novel ANN model. All models described in this section were trained on a set of 381539 peptides, and tested on a set of 1917 peptıdes - every $200^{\text {th }}$ peptıde was chosen for the test set, 
after the peptides were ordered alphabetically, in order to produce a test set which is representative of a range of peptides. Computational requirements prevented the use of more in depth testing methods such as cross validation. The metric used to determine the success of an ANN model was test set mean squared error (MSE). Both hidden and output layers of the neural network employ sigmoidal activation functions, and all test ANNs were trained for 1000 epochs using the resilient backpropagation training algorithm, an adaptive variation of the backpropagation algorithm which sets the learning rate parameter at each epoch based on current learning success (Riedmiller, 1994).

\section{Amino acid frequencies}

A proven alternative to the orthogonal encoding used by the 1052-input model is a 20-input model which encodes the frequency of each of the 20 amino acids present in the peptide. This encoding of the peptide structure is the basis for our ANN model. The training set provided to us makes a distinction between alkylated cysteine and unmodified cysteine. Our model, therefore, makes the same distinction, increasing the number of inputs to 21 . This 21-input model produces a MSE of 0.001553 .

Shinoda et al. have suggested a variation of this model which eliminates four inputs, relating to four amino acids which have a negligible effect on peptide hydrophobicity (Shinoda et al., 2006). However, our testing has shown that a 17-input model which removes hydrophobically neutral amino acids produces a MSE of 0.001741 , higher than the 21-input model. Therefore, we have chosen the 21-input peptide encoding scheme as the basis for our ANN model. 


\section{Hydrophobic Moment}

The hydrophobic moment of a peptide is a function of the secondary structure of a peptide, resulting from helical structures which contain hydrophobic or hydrophilic amino acids on their surfaces. This property was discovered by Eisenberg et al. (Eisenberg, Schwarz, Komaromy, \& Wall, 1984), who define hydrophobic moment as follows:

$$
\mu_{H}=\left\{\left[\sum_{n=1}^{N} H_{n} \sin (2 n \pi / 3.6)\right]^{2}+\left[\sum_{n=1}^{N} H_{n} \cos (2 n \pi / 3.6)\right]^{2}\right\}^{1 / 2}
$$

Where $n$ indexes the amino acids in the peptide, and $H_{n}$ is a constant which has been derived experimentally for each amino acid. Petritis et al. utilize the hydrophobic moment in their 1052-input model.

When added to the 17-input model, the hydrophobic moment reduces MSE on the test set from 0.001741 to 0.001450 . Because the inclusion of hydrophobic moment reduces MSE on the test set, hydrophobic moment has been included in our final ANN model.

\section{Peptide Length and Mass}

In addition to peptide encoding and hydrophobic moment, Petritis et al. have incorporated peptide length into the state of the art 1052-input model. Thus, we have tested a model using both hydrophobic moment and length in addition to the 21-input peptide encoding described previously. This model produced a test set MSE of 0.001361 . As an alternative to peptide length, we have also explored the use of peptide mass, as peptide mass is a more accurate indicator of peptide size. A model containing the 21-input peptide encoding, hydrophobic moment and peptide mass 
produced a test set MSE of 0.001338 . Therefore, we have chosen to use peptide mass as an ANN input instead of the peptide length as used in previous papers.

\section{Orthogonal Encoding of Terminal Amino Acids}

Peptıde retention tıme depends largely on the identıty of amıno acıds at the $\mathrm{N}$ - and C- terminal locations of the peptide. Therefore, while it may not be feasible to orthogonally encode all amıno acıds withın the entıre peptıdes, it could be useful to orthogonally encode the termınal amıno acıds. We have explored this optıon, first by encoding the peptide at the C-termınus. Note that because the peptide was the product of tryptıc digestıon, only amıno acıds argınıne or lysıne can be present in thıs location, so only two inputs were used to encode this information. Encoding the Ctermınal amıno acıd did not, however, ımprove the test set MSE of the model; the MSE usıng these ınputs was 0.001355 . Sımılarly, encodıng the $\mathrm{N}$-termınal amıno acıd produced a test set MSE of 0.001349 , which is not an improvement over a model that does not orthogonally encode any termınal amıno acıds. Therefore, we have chosen not to include these inputs in our model.

\section{Number of Hidden Nodes}

Two of the definıng features of any ANN model are the number of hidden layers in the architecture and the number of hidden nodes per layer. Because all previous successful ANN implementations for retention time prediction have used a single hıdden layer (Shınoda et al., 2006) (Petritıs et al., 2006) (Petritıs et al., 2003), we have decided to use a single layer in our model. We have tested a range of hidden node numbers using the optımal 23-input configuration, and found that 10 hidden nodes appears to be suitable, as can be seen In Figure 5-2; beyond 10 hidden nodes, It appears as though any deviation in test set MSE is the result of statistical noise. This number of hidden nodes is significantly higher than previous successful ANN 
architectures with similar numbers of inputs. Repetition of this experiment would eliminate the effects of noise in the test results and produce a more statistically robust answer to the question of the optimal number of hidden nodes in the architecture, however, training a single ANN model on a large dataset requires several hours of computation. Time constraints prevent repetitions of experiments from being performed.

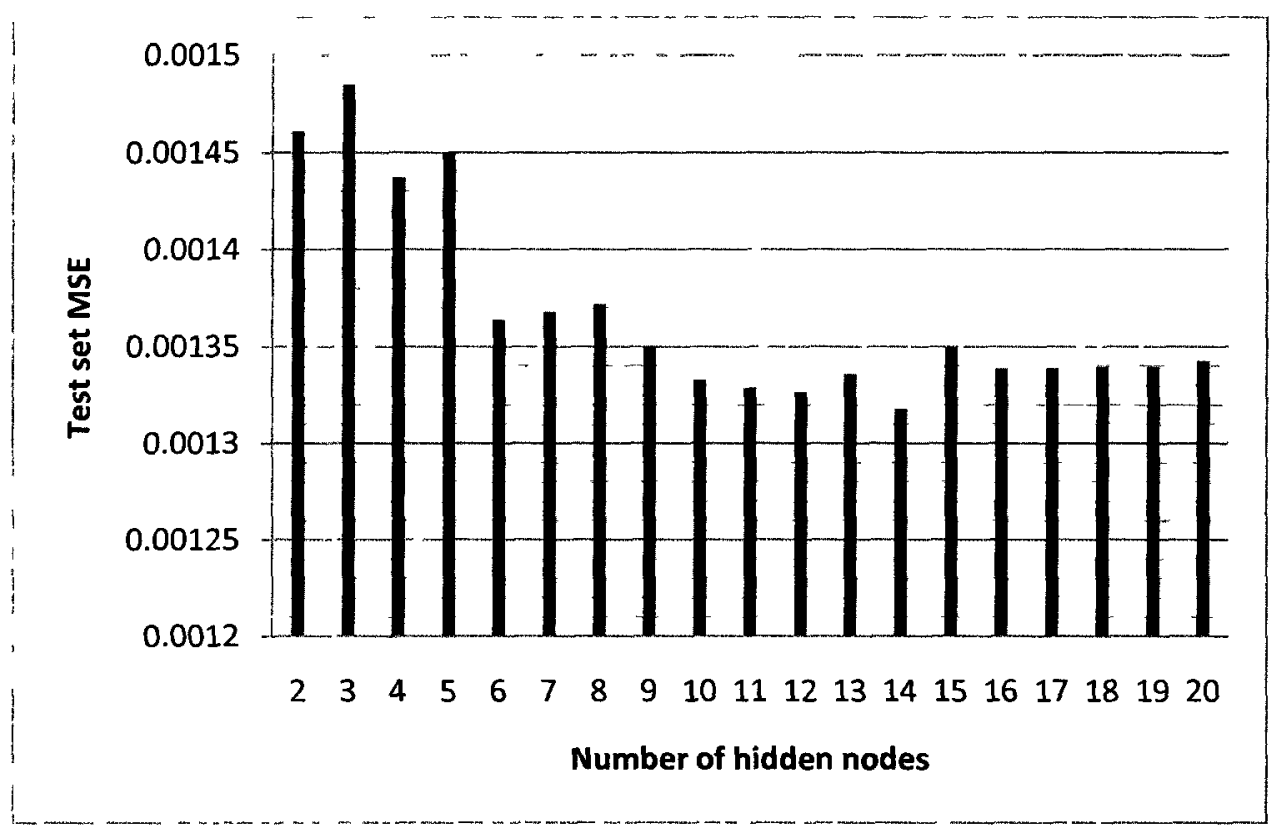

Figure 5-2 - Test set MSE for varying numbers of hidden nodes in ANN architecture. MSE is optimal for 14 hidden nodes, however there is no clear downward trend past 10 nodes.

\section{Number of Training Epochs}

As a final step in optimizing the accuracy of our ANN architecture, we have varied the number of epochs for which the ANN is trained; an ideal number of epochs used during training balances under- and over-fitting to the training set data. Figure 5-3 demonstrates that 900 epochs is a suitable training length for our model; increasing the number of epochs beyond 900 does not have a consistently positive effect. As with the optimization of number of hidden nodes, computational requirements and time constraints prevent repetition of experiments. 


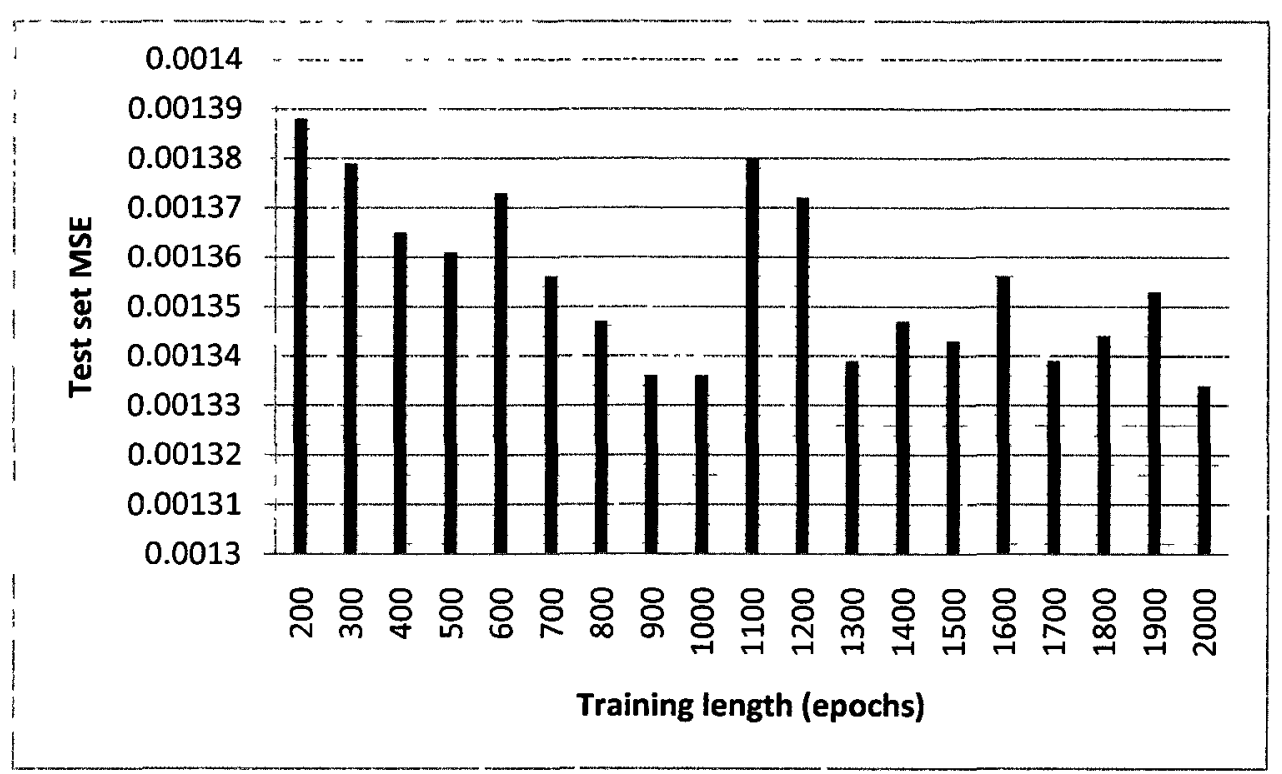

Figure 5-3 - Test set MSE over varying training lengths. Training beyond 900 epochs does not appear to produce beneficial results

Results of detailed ANN model testing can be seen in section 5.5.1.

\subsection{The Retention Time / Experiment Time Mapping Algorithm}

As mentioned previously, the objective of the retention time / experiment time mapping module is to produce a retention time value which represents the most likely current retention time value given the evidence that we have seen from the mass spectrometer up to this point. Evidence is provided by matches between the masses of AMT database points and the masses of peptides which are currently eluting from the liquid chromatography column, as measured by the most recent MS survey scan.

\subsubsection{Producing a Probability Density Function}

We have employed a Parzen Window technique, which aims to estimate a random variable based on a sum of kernel functions, in order to produce a probability density function in the space of the AMT database. If we observe the AMT mass/time plot as a 2-dimensional probability space, then a sum of kernel functions, each of which is centered on a mass/time pairing from the AMT database, produces such a probability 
density function (PDF). Given a mass which has been produced by the mass spectrometer and an arbitrary time value, this PDF estimates the likelihood that this observed mass/time pair relates to any known peptide in the AMT database. In other words, for a given experimental mass, we can determine the extent to which this mass supports the hypothesis "We are currently at retention time $t$ " for all times in the range $0<=t<=1$. The amount of support for each time that this experimental mass provides can be pictured as a one-dimensional PDF, as seen in Figure 5-4.

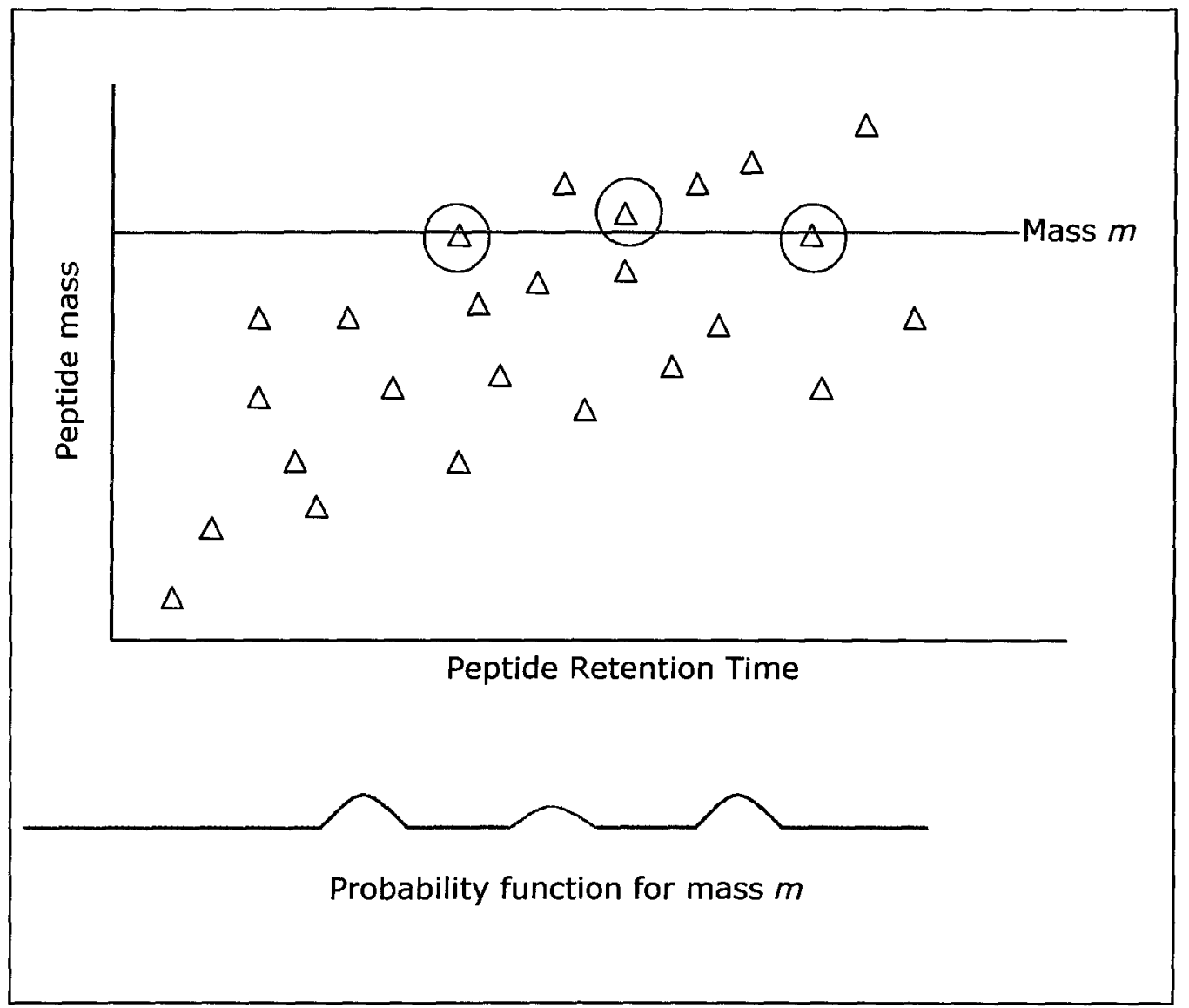

Figure 5-4 - Creation of kernel function from 2D AMT database. A peptide mass $m$, represented by the blue line, was observed in the mass spectrometer. The resulting probability function is the result of kernel functions centered around the three AMT database points which have a mass close to $\mathbf{m}$. 
We have chosen as the kernel function $K_{p}$ a Gaussian function of the form.

$$
K_{p}(m, t)=e^{\frac{\left(m-m_{P}\right)^{2}}{2 \sigma_{m}}-\frac{\left(t-t_{P}\right)^{2}}{2 \sigma_{t}}}
$$

Where:

- $m$ is the observed experımental mass

- $m_{p}$ is the AMT database mass of the peptide at the center of the kernel

- $\sigma_{m}$ is a mass standard deviation, which is determined by the accuracy of the mass spectrometry hardware

- $\sigma_{t}$ is the time standard deviation, which is a function of the accuracy of the retention tıme prediction model

- $t$ is the experimental tıme

- $t_{p}$ is the AMT database time of the peptide at the center of the kernel

The Gaussian function accurately models a mass spectrometer which produces an unbiased estımate of mass, and for which $m$ and $t$ are independent. Because this is not the case for all mass spectrometers, alternate kernel functions may be required In order to produce correct results on all hardware. All hardware used for testing fall Into the former category, therefore testıng of alternate kernel functions for hardware which produces biased mass results was not performed. This kernel function will perform adequately for almost all mass spectrometry hardware, and the algorithm described in this section can be adapted to alternate kernel functions trivially.

With a 2-dimensional probability density function established, it is possible to produce a value which, for a list of experımental mass values, represents the most lıkely retention time value for the currently observed data.

For each retention tıme value $t, 0<=t<=1$, the amount of support $S$ for $t$ being the correct retentıon tıme value, given a database with P known mass-tıme pairs, 
and a list of $L$ currently observed experimental masses, can be calculated using the following formula:

$$
S(t)=\sum_{l=1}^{L} \sum_{p=1}^{P} K_{p}\left(m_{l}, t\right)
$$

The retention time value which corresponds to the maximum of this support function is the retention time value which is most likely to correspond to the current experimental time.

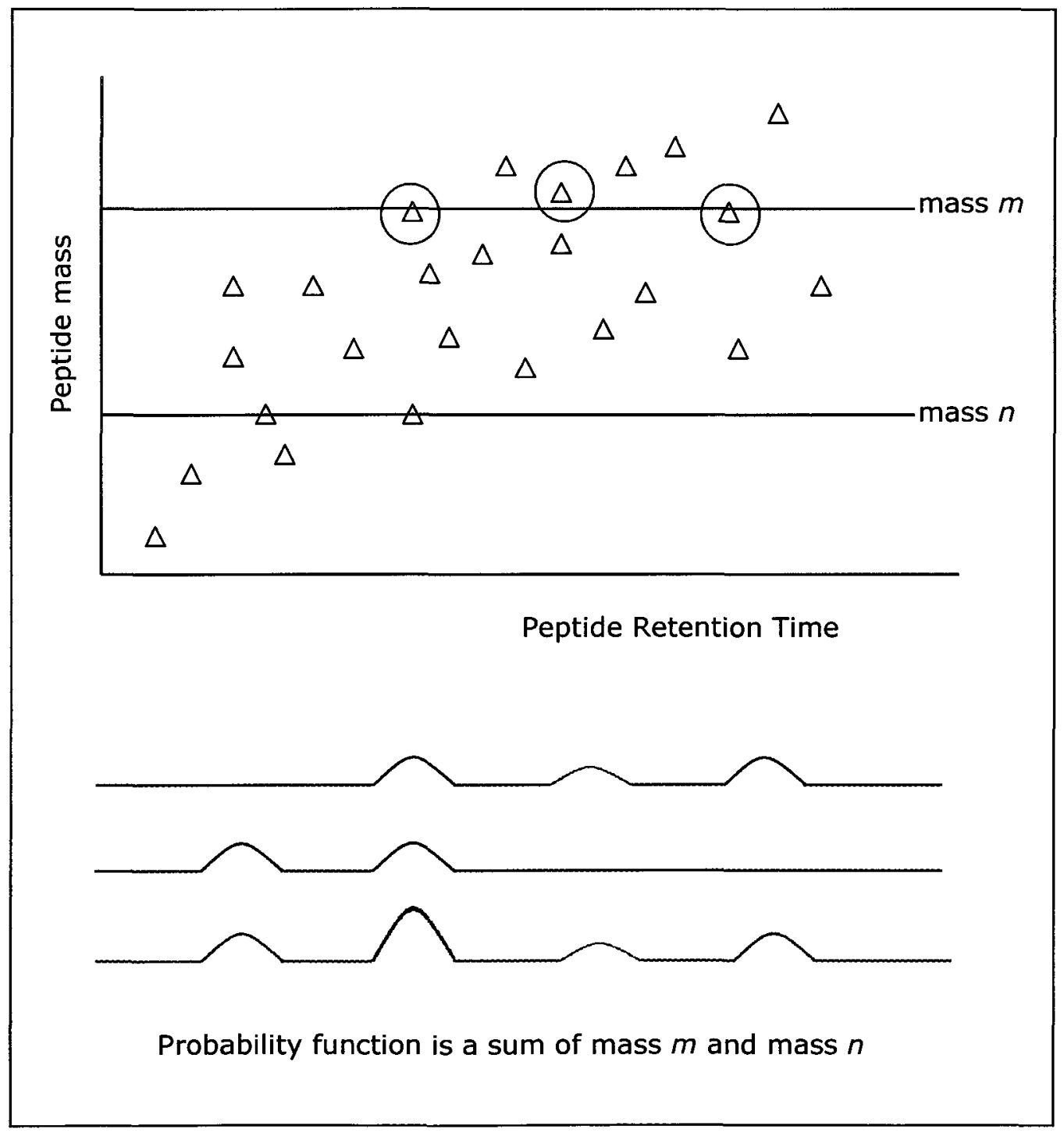

Figure 5-5 - Production of a support function from multiple recorded masses. Masses $m$ and $n$, was observed in the mass spectrometer. The resulting support function, seen in purple, is the sum of the blue and red functions. A maximum of the function appears where evidence is provided by both recorded masses. 
Because the support function relies only on AMT database information which is known prior to an experıment, the support function could be pre-computed in a finegraıned mesh, removing the need to repeatedly compute exponential functions during real-tıme operation. Given this optımızation, the retentıon tıme / experıment tıme mapping algorithm is not expected to require a significant portion of the processıng tıme avaılable between real-tıme deadlınes.

\subsubsection{Finding the Global Maximum of the Support Function}

The preceding section of this thesis presents a function whose maximum represents the most likely retention tıme value relatıng to the current tıme in a mass spectrometry experıment. Calculatıng thıs maxımum, however, is non-trivial. There is no computational method which can directly calculate the global maximum of a polymodal function, and function estımation methods are computationally expensıve. Because of these factors, we have explored several technıques for findıng the maxımum of the support function, $S(t)$.

\subsubsection{Naive Scanning Approach}

As a baselıne approach for finding the maximum of the support function, we have ımplemented a naive scannıng algorithm for the function. This algorithm calculates the value of the support function for all $t$ values in a finite set, then returns the maxımum value among those calculated. Our implementation of this algorithm uses the set

$$
\{t \mid t=0.0001 n, 0<=t<=1, n \in \mathrm{I}\}
$$

While this algorithm returns a value which is only an estimation of the true location of the maximum of the support function, this approach is attractive because it is hıghly parallelizable. The result at each tıme $t$ is completely independent of all other 
results, so each of these results can be calculated in parallel, resultıng in significant speedup.

\subsubsection{Golden Section Search}

The golden section search (Kiefer, 1953) is an iterative method which is capable of estımatıng the maxımum or mınımum of a unımodal functıon by narrowıng the range In which this maxımum can be found by a set percentage at each iteration. The range in which the maximum could exist is defined by three points along the function, $f\left(t_{1}\right) f\left(t_{2}\right)$ and $f\left(t_{3}\right) . f\left(t_{1}\right)$ and $f\left(t_{3}\right)$ represent the boundary points of this range of the function, while $f\left(t_{2}\right)$ is a point which is in between $f\left(t_{1}\right)$ and $f\left(t_{3}\right)$. At each Iteration of the algorithm, a point $f\left(t_{4}\right)$ is chosen in between $f\left(t_{2}\right)$ and either $f\left(t_{1}\right)$ or $f\left(t_{3}\right)$ - whichever is farther from $f\left(t_{2}\right)$. If the function is higher at $f\left(t_{4}\right)$ than at $f\left(t_{2}\right)$, then the new range in which the maximum resides is defined by points $f\left(t_{2}\right), f\left(t_{4}\right)$, and whichever of $f\left(t_{1}\right)$ and $f\left(t_{3}\right)$ are farther from $f\left(t_{2}\right)$. If the function at point $f\left(t_{4}\right)$ is lower than $f\left(t_{2}\right)$, then the maximum resides in a range which is defined by points $f\left(t_{2}\right), f\left(t_{4}\right)$, and whichever of $f\left(t_{1}\right)$ and $f\left(t_{3}\right)$ are closer to $f\left(t_{2}\right)$ along the time axis. By choosing point $f\left(t_{4}\right)$ such that $t_{4}=t_{1}-t_{2}+t_{3}$, the algorithm is guaranteed to reduce the range by a factor of $1-1 / 1.618033$ or approxımately $38 \%$. Given the total range of $0<=t<=1$, this algorithm is capable of approximating $t$ to a precision of $+/-$ 0.001 withın 14 iteratıons.

Because the support function, $S(t)$, is expected to be polymodal, it is necessary to provide initial boundaries for the golden section search which divide $S(t)$ into a series of sectıons which are unımodal, or unımodal for the majority of the tıme range. In order to provide the algorithm with near-unımodal sections of the support function, the support function has been split into initial ranges which are defined on one side by the time of an AMT database point, and on the other side by the midpoint 
between the time of the AMT database point and the time of the previous or next AMT database point, assuming all AMT database points are ordered by time. The sum of two Gaussian curves, such as those produced by adjacent AMT database points, will have at most one local minimum. If the two Gaussian curves are approximately equal in terms of height, the minimum will occur between the two centers of the Gaussians as seen in Figure 5-5 and the golden section search algorithm will perform well for both ranges.

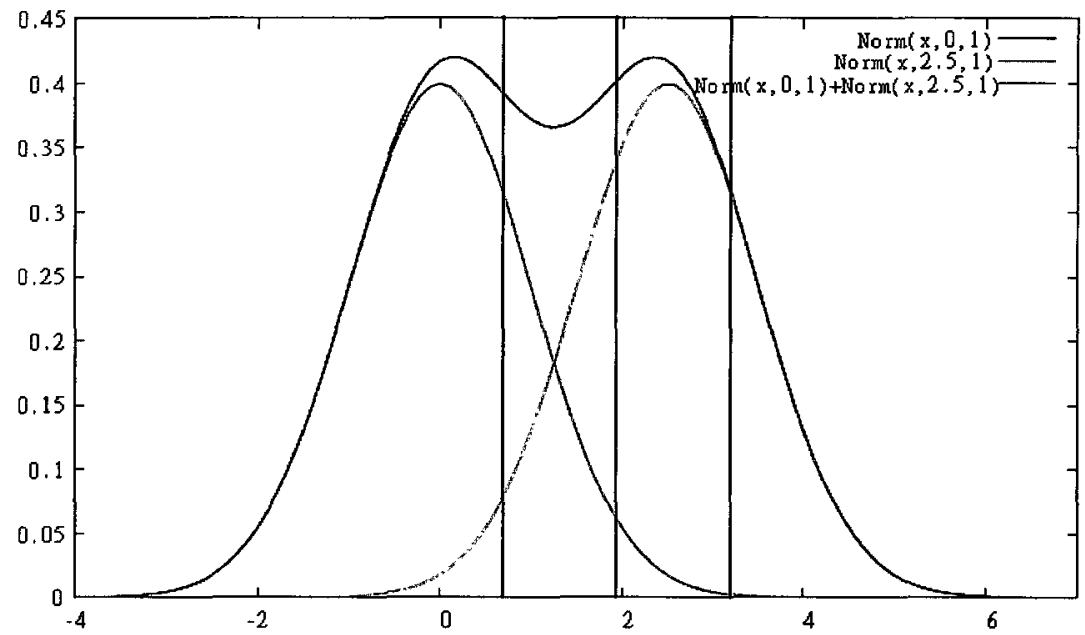

Figure 5-5 - Golden section search ranges (pictured as vertical lines) relating to the sum of two gaussian curves of equal magnitude. The support function, in blue, would be seen as unimodal by the golden section search algorithm for each of the two sections of interest.

If one Gaussian is significantly larger than the other, then the local minimum may occur in a position which causes one golden section search to produce an erroneous result. However, if this is the case, then the maximum within the non-unimodal range will be dwarfed by the maximum in the adjacent unimodal range, so the algorithm as a whole (which aims to produce a global maximum of the function) will not produce an erroneous result. A demonstration of this effect can be seen in Figure 5-6. 


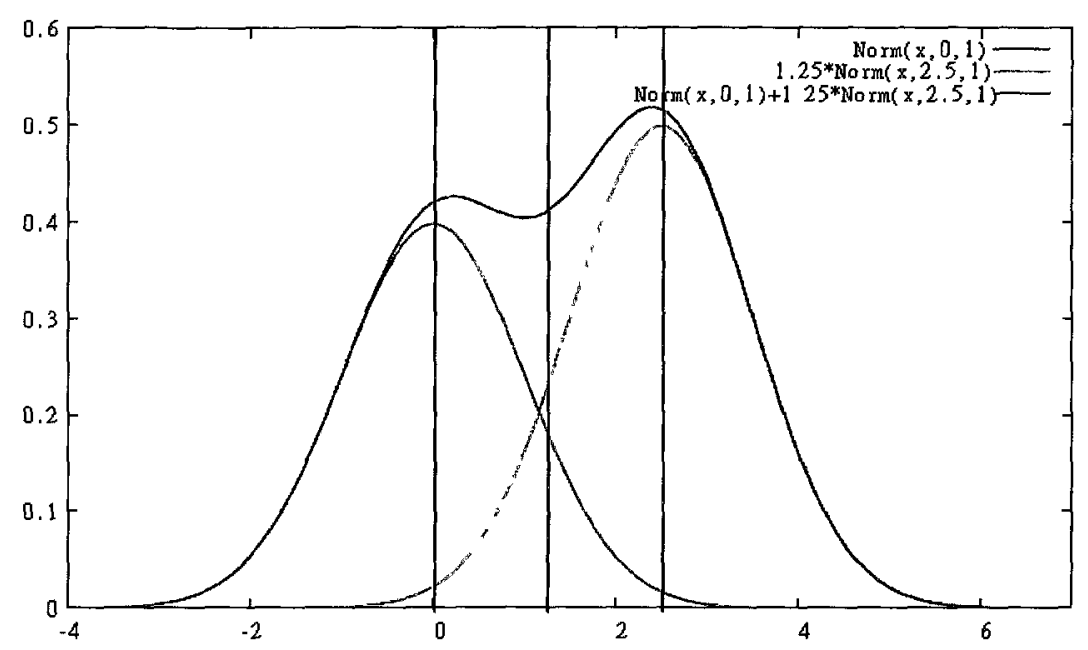

Figure 5-6 - Golden section search over Gaussians of different amplitudes. The left region is clearly polymodal, and the golden section search may fail in this region, however the right section contains the global maximum and the golden section search will succeed in this region. Boundaries for the search are marked with vertical lines, and the support function is drawn in blue.

By performing several golden section searches over the ranges previously specified, we can be assured that the algorithm will produce an optimal result.

While theoretically more accurate than the naive scanning algorithm, the golden section search algorithm is not as parallelizable. For a golden section search with $N$ iterations, the support function must be calculated in serial at $N+2$ points. Golden section searches over different sections of $S(t)$ are independent of each other, so parallelization can occur across searches, however the ideal implementation of a golden section search for our purposes will result in a $N+2$-times slow down relative to an ideal implementation of the naive scanning algorithm. For our purposes, this represents an order of magnitude slowdown relative to the scanning approach.

\subsubsection{Gradient Ascent Search}

The gradient ascent search algorithm is similar to the golden section search algorithm, in that it is capable of finding an approximation to the maximum or minimum of any unimodal function. Each gradient ascent search is initialized with a 
time value which serves as a best estimate of the maximum of the function. The slope of the function is then calculated at this time value, and this slope multiplied by a small constant $y$ (i.e. step size or learning rate) is added to the initial bestestimate time. This process is repeated for a finite number of iterations, eventually settling on a local maximum where the slope is near-zero and thus no change in the estimate occurs.

As with golden section searches, gradient ascent searches are only able to find the maximums of unimodal functions. Therefore, multiple gradient ascent searches must be launched in order to assure that the global maximum of the polymodal support function is found. In performing gradient ascent searches on the support function, we have chosen as initial values the time values of each of the AMT database points. Given the interactions of Gaussians when summed as described in the previous section, these starting points ensure that the global maximum of the function will be determined.

As with the golden section search, the gradient ascent search requires sequential calculations of support function values for each gradient ascent, however multiple gradient ascents are independent and parallelizable. For the parameters used in our experiments $-\mathrm{Y}=0.0001$ and 1000 iterations - each gradient ascent would require $1000+1$ sequential support function calculations and would therefore be slower than the naive scanning algorithm by a factor of up to 1001. Early stopping conditions for the algorithm can mitigate this high number of serial calculations, however the worst case scenario is still significantly slower than the naive scanning algorithm for a parallel system. 


\subsubsection{Experimental Setup}

The retention tıme / experıment tıme mappıng algorıthm has been tested on a LCMS/MS run of a "protmıx" sample contaınıng 7 proteıns. The LC for the experıment has been set for a lınear gradıent whıch extends for 30 mınutes, usıng a lınear Interpolation between the following points: $2 \%$ at $0 \mathrm{~min}, 5 \%$ at $0.5 \mathrm{~min}, 18 \%$ at 5 $\mathrm{mın}, 30 \%$ at $16 \mathrm{~m} ı \mathrm{n}, 70 \%$ at $25 \mathrm{mın}, 100 \%$ at $25.1 \mathrm{mın}, 100 \%$ at $28 \mathrm{~m} ı \mathrm{n}, 2 \%$ at $28.1 \mathrm{mın}, 2 \%$ at $30 \mathrm{mın}$. The retention tımes of the 9 most confidently identıfied peptıdes were predıcted usıng our ANN model. Confidence of peptıde Identification was determıned by the Mascot data analysıs sulte (http://www.matrixscience.com/). The predıcted retention tıme values for these 9 peptıdes were then compared agaınst the estımated retention tımes for survey scans durıng which the peptides were present in the mass spectrometer. Thus, the algorithm was tested on its ability to correctly predict the elution of important peptıdes. The average mean squared error between these calculated and predicted values is used as a measure of success for the retentıon tıme / experıment tıme mappıng algorıthm.

\subsection{Results and Discussion}

\subsubsection{ANN Retention Time Estimation Model Accuracy}

In order to compare our ANN retention tıme estımatıon model to existıng models, we have examıned the $\mathrm{R}^{2}$ value of the model outputs to correspondıng retention tımes of the 1917 peptıdes in the test set described above. Usıng our 23-ınput model, we have achieved a $R^{2}$ value of 0.9483 . This value is below the value achieved by the 1052-Input model proposed by Petritıs et al. (0.967), but is sıgnificantly higher than both the 16-ınput model proposed by Shınoda et al. (0.928) and the 20-Input model proposed by Petritis et al. (0.87) upon which this model is based. Figure 5-7 demonstrates the plot upon which this value has been derived. The increase in 
accuracy of this model is largely due to the inclusion of the hydrophobic moment ANN input.

A summary of mean squared error values for ANN input configurations described in this paper can be seen in the proceeding table:

Table 5-1 - Test MSE values for ANN input configurations considered during development of final ANN model

\begin{tabular}{|l|l|}
\hline ANN input configuration & MSE \\
\hline 21 AA frequencies & 0.001553 \\
\hline 17 AA frequencies & 0.001741 \\
\hline 17 AA frequencies + hydrophobic moment & 0.001450 \\
\hline 21 AA frequencies + hydrophobic moment + peptide length & 0.001361 \\
\hline 21 AA frequencies + hydrophobic moment + peptide mass & 0.001338 \\
\hline
\end{tabular}

Note that different test and training sets have been used for each of the previously reported experiments and this current experiment. The results of these experiments are not a direct comparison, however the increase in accuracy over existing lowinput models is significant regardless of differences in experimental methods. 


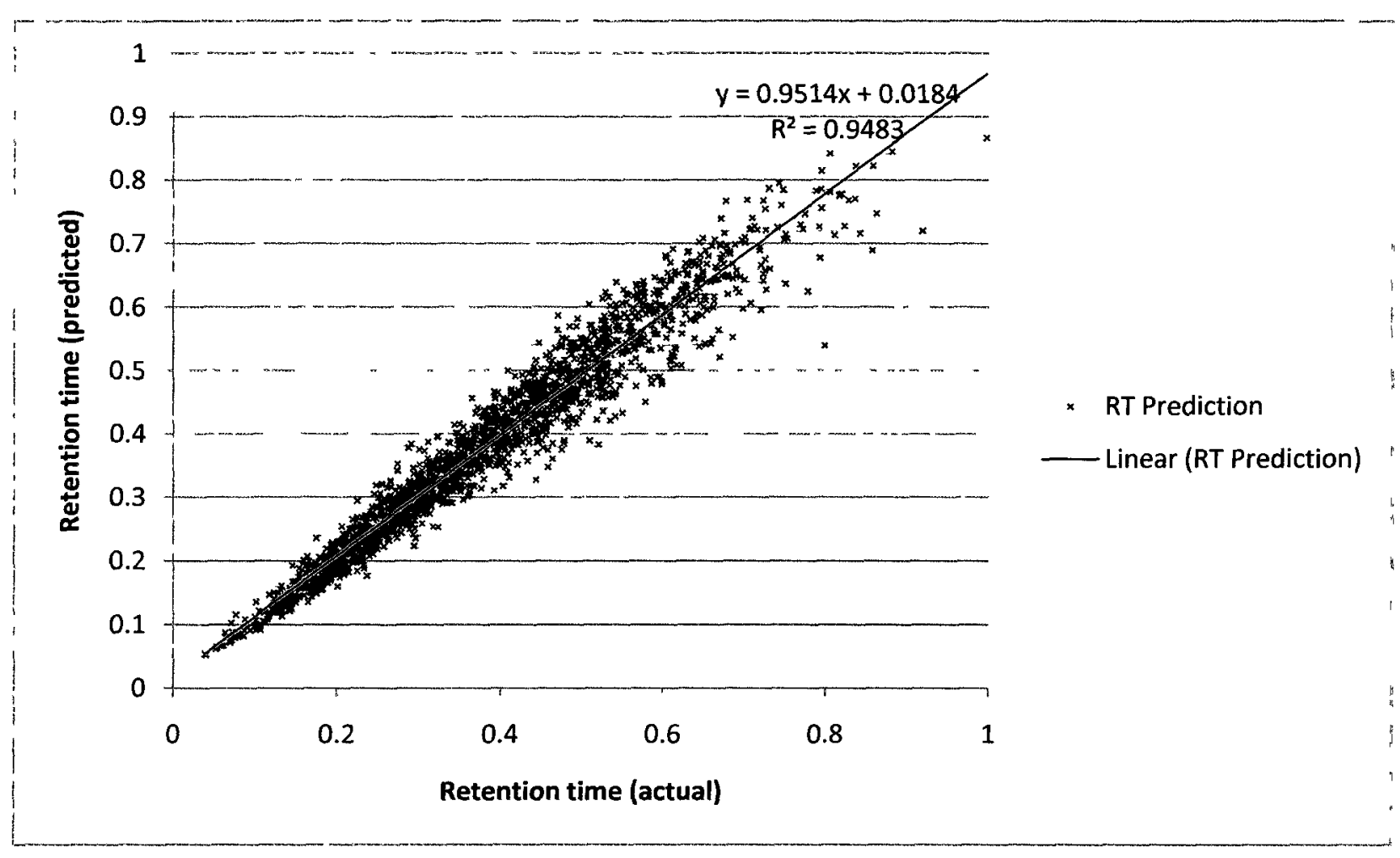

Figure 5-7 - Plot of predicted retention time of ANN model vs. actual retention time

\subsubsection{Retention Time / Experiment time Mapping Accuracy}

Using the scanning method of calculating the maximum of the support function, we have predicted the elution times of 9 high-confidence peptides with a mean squared error of 0.00627 . All three of the methods used for determining the maximum of the function produced a MSE which is within 0.00001 of this value, which indicates that the three methods produce the same results to within a small margin of error. Tables 5-2 through 5-4, below, display the results of these tests. When calculating the retention time value of the experiment based on the elution time and the LC gradient information provided in section 5.4.3, we see a MSE of 0.00671 . Therefore, our methods more accurately predict the retention time of the experiment during elution of these 9 peptides. 
Because each of the three methods performed extremely similarly during our tests, the high simplicity and parallelizability of the naive scanning methods makes it an ideal candidate for determining the maximum of the support function.

Table 5-2 - Test results for the naive scanning method for retention time / experiment time prediction

\begin{tabular}{|c|c|c|c|}
\hline Peptide Sequence & $\begin{array}{l}\text { Actual } \\
\text { retention } \\
\text { time }\end{array}$ & $\begin{array}{l}\text { Estimated } \\
\text { retention time }\end{array}$ & Error $^{2}$ \\
\hline LLGLFPDAN & 0.38823 & 0.372487 & 0.000247842 \\
\hline VGLSASTGLYK & 0.440501 & 0.410982 & 0.000871371 \\
\hline DLILQGDATTGTDGNLELTR & 0.28547 & 0.416382 & 0.017137952 \\
\hline SPDSHPADGIAFFISNIDSSIPSGSTGR & 0.315807 & 0.470375 & 0.023891267 \\
\hline LGEYGFQNAILVR & 0.36881 & 0.328293 & 0.001641627 \\
\hline GLSDGEWQQVLNWWGK & 0.35261 & 0.407583 & 0.003022031 \\
\hline VNVDEVGGEALGR & 0.258118 & 0.300397 & 0.001787514 \\
\hline DILNQITKPNDVYSFSLASR & 0.434742 & 0.347091 & 0.007682703 \\
\hline QTALVELLK & 0.44668 & 0.432879 & 0.000190468 \\
\hline & & & $\begin{array}{r}\text { MSE: } \\
0.00627475\end{array}$ \\
\hline
\end{tabular}


Table 5-3 - Test results for the golden section search method for retention time / experiment time prediction

\begin{tabular}{|c|c|c|c|}
\hline Peptide & $\begin{array}{l}\text { Actual } \\
\text { retention } \\
\text { time }\end{array}$ & $\begin{array}{l}\text { Estimated } \\
\text { retention time }\end{array}$ & Error $^{2}$ \\
\hline LLGLFPDAN & 0.38823 & 0.372503 & 0.000247339 \\
\hline VGLSASTGLYK & 0.440501 & 0.411055 & 0.000867067 \\
\hline DLILQGDATTGTDGNLELTR & 0.28547 & 0.416406 & 0.017144236 \\
\hline SPDSHPADGIAFFISNIDSSIPSGSTGR & 0.315807 & 0.470408 & 0.023901469 \\
\hline LGEYGFQNAILVR & 0.36881 & 0.328223 & 0.001647305 \\
\hline GLSDGEWQQVLNWWGK & 0.35261 & 0.407653 & 0.003029732 \\
\hline VNVDEVGGEALGR & 0.258118 & 0.300481 & 0.001794624 \\
\hline DILNQITKPNDVYSFSLASR & 0.434742 & 0.347123 & 0.007677094 \\
\hline QTALVELLK & 0.44668 & 0.432887 & 0.000190247 \\
\hline & & & MSE: 0.00627767 \\
\hline
\end{tabular}


Table 5-4 - Test results for the gradient ascent search method for retention time / experiment time prediction

\begin{tabular}{|c|c|c|c|}
\hline Peptide & $\begin{array}{l}\text { Actual } \\
\text { retention } \\
\text { time }\end{array}$ & $\begin{array}{l}\text { Estimated } \\
\text { retention } \\
\text { time }\end{array}$ & Error $^{2}$ \\
\hline LLGLFPDAN & 0.38823 & 0.372474 & 0.000248252 \\
\hline VGLSASTGLYK & 0.440501 & 0.411023 & 0.000868952 \\
\hline DLILQGDATTGTDGNLELTR & 0.28547 & 0.416427 & 0.017149736 \\
\hline SPDSHPADGIAFFISNIDSSIPSGSTGR & 0.315807 & 0.470373 & 0.023890648 \\
\hline LGEYGFQNAILVR & 0.36881 & 0.328294 & 0.001641546 \\
\hline GLSDGEWQQVLNWWGK & 0.35261 & 0.407624 & 0.00302654 \\
\hline VNVDEVGGEALGR & 0.258118 & 0.300534 & 0.001799117 \\
\hline DILNQITKPNDVYSFSLASR & 0.434742 & 0.347133 & 0.007675342 \\
\hline QTALVELLK & 0.44668 & 0.432883 & 0.000190357 \\
\hline & & & MSE: 0.00627672 \\
\hline
\end{tabular}




\section{Thesis Summary and Future Recommendations}

\subsection{Conclusions}

In exploring the problem of peptıde sequence tag matching on parallel hardware, we have developed the orthogonal Parabıx algorithm, a novel extensıon of the Parabıx algorithm which is extremely well-suited to searchıng peptıde sequence tags agaınst large proteomic or genomic databases. This algorithm, as implemented on both the Cell B/E and GPU platforms, outperforms all exıstıng string matchıng algorithms under typıcal searches required by IdMS/MS. The orthogonal Parabıx algorithm has sustaıned search throughputs of 2066 Gbit/s on a Nvıdıa GTX 570 graphıcs card, 943 Gbit/s on a Nvidıa GTX 260 graphics card, and 216 Gbit/s on a Cell B/E QS22 blade server. The orthogonal Parabıx algorithm is capable of searchıng both six-frame genomic databases and proteomic databases at these throughputs, and is capable of handling specific query ambiguities which arıse from de novo sequencing of product Ion spectra. Given the success of Implementıng the orthogonal Parabix algorithm on commodity parallel hardware, we belıeve that these platforms are suitable for meetıng the deadlınes of real-tıme MS/MS data analysıs; the GPU platform in partıcular appears to be well suited to this type of data-ıntensive computation.

We have also developed an algorithm whıch maps experıment wall tıme to retention tıme as the experiment occurs through the novel use of statıstical methods. This algorithm is the first of its kınd, as prior to the inception of IdMS/MS, data analysıS was performed strictly offlıne after the experıment. This algorithm does not require ınput from the user prior to or during the experıment and can map experıment tıme to arbitrary elution curves, which opens up the possibility of directed MS/MS studies without prior knowledge or calibratıon of instrument elution curves. As a step in the 
creation of the retention tıme / experıment tıme mapping algorithm, we have developed a novel ANN topology which predicts retention times of peptides with a $R^{2}$ value of 0.9483 usıng only 23 input nodes and 10 hidden nodes. The retentıon tıme / experiment tıme mappıng algorıthm was able to successfully predict the retention tıme of an experıment during the elution of nıne confidently identified peptides durıng a real LC-MS/MS experıment, resultıng in a MSE of 0.00627 between predicted current retention time and retention time of identified peptides. The algorıthm used only data avalable to the mass spectrometer durıng an experıment.

\subsection{Summary of contributions}

In this thesis, we have thoroughly explored the problem of peptide sequence tag matchıng agaınst large genomıc and proteomıc databases. We demonstrated the first implementation of several well-established string matching algorithms on the Cell $B / E$, and Introduced the orthogonal Parabıx algorithm, a strıng matchıng algorıthm which is highly tallored to mass spectrometry data analysıs. This algorithm outperforms all competıng algorithms by an order of magnitude when searches are performed under typical peptıde sequence tag search conditions. The orthogonal Parabıx algorithm was ımplemented on the Cell B/E and GPU platforms, is capable of searchıng sıx-frame genomic databases without any effect on search throughput, and accurately models query ambiguities which arıse from de novo sequencing of product Ion spectra.

We have also developed an algorithm which maps experıment wall tıme to retention tıme as the experıment is performed. This algorithm extends the idea of accurate mass/tıme databases as probabılity spaces by employıng parzen window techniques combıned with function maxımızation in order to determıne the retention time which has the hıghest probabılity of occurrıng based on the precursor ion masses which are 
currently being seen in the mass spectrometer. The algorithm also makes use of a novel ANN topology which produces accurate retention time predictions for peptides with a relatively small number of nodes. Our retention time / experiment time mapping algorithm is the first algorithm which is capable of mapping retention time to wall time as the experiment proceeds, which increases the capabilities of directed MS/MS experiments while enabling the idMS/MS system.

\subsection{Recommendations for future work}

As this thesis represents the first steps toward a complete idMS/MS system, there is a number of future steps which must be taken in order to implement the idMS/MS pipeline in its entirety. First and foremost, an interface must be developed which allows the idMS/MS system to communicate with mass spectrometry hardware. This interface will most likely be developed using modifications to existing middleware applications such as Applied Biosystems' AnalystQS software. The creation of this interface would define the information which we receive and transmit to the mass spectrometry hardware during the experiment, and as such would determine the functional and non-functional requirements of any idMS/MS system.

Another key step in the creation of the idMS/MS pipeline is the development of a parallel de novo sequencing algorithm. De novo sequencing is a computationally intensive but highly parallelizable task which is a critical step in the pipeline and must be performed within real-time deadlines. As a possible alternative to de novo sequencing, spectral database searching could be used in order to determine peptide information present in a product ion spectrum.

A final and important element of the idMS/MS pipeline which must be implemented is a module which scores precursor ions based on the likelihood that these ions will be 
important to the experiment. One possible implementation of this module is an information theoretic framework; this framework would receive as inputs lists of ambiguously identified and confidently identified proteins, peak masses and intensities from the most recent MS survey scan, current retention time, and peptide retention times. Using these factors, the framework would score all peaks from the most recent MS survey scan based on the amount which they would reduce entropy within the probability space of unidentified proteins.

Within the retention time / experiment time mapping algorithm, there are several logical next steps which could be performed. Iterations of the algorithm must be performed within the real-time deadlines of mass spectrometry hardware, therefore elements of the algorithm must be parallelized. Obvious candidates for parallelization are the three algorithms which determine the global maximum of the support function. It is also possible that interpolation or smoothing techniques which incorporate data from several survey scans into a single retention time prediction value would improve the accuracy of retention time predictions. For example, simple linear regression of the most recent $n$ points would likely produce a result that is much more resilient to distortion caused by a single data point which is not representative of the retention time trend. 


\section{References}

Aebersold, R., \& Mann, M. (2003). Mass spectrometry-based proteomics. Nature, 422(6928), 198-207. doi: 10.1038/nature01511.

Aho, A. V., \& Corasick, M. J. (1975). Efficient string matching: an aid to bibliographic search. Communications of the ACM, 18(6), 333-340. doi: $10.1145 / 360825.360855$.

Alex, A. T., Dumontier, M., Rose, J. S., \& Hogue, C. W. V. (2005). Hardwareaccelerated protein identification for mass spectrometry. Rapid communications in mass spectrometry : RCM, 19(6), 833-7. doi: 10.1002/rcm.1853.

Anderson, K. K., Monroe, M. E., \& Daly, D. S. (2006). Estimating probabilities of peptide database identifications to LC-FTICR-MS observations. Proteome science, 4, 1. doi: 10.1186/1477-5956-4-1.

Anderson, K. K., Monroe, M. E., Daly, D. S., \& Valafar, F. V. and H. (2004). Estimating Probabilities of Peptide Assignments to LC-FTICR-MS Observations. Retrieved July 12, 2011, from http://www.osti.gov/energycitations/product.biblio.jsp?osti_id=15009510.

Babushok, V.. I., \& Zenkevich, I. G. (2010). Retention Characteristics of Peptides in RP-LC: Peptide Retention Prediction. Chromatographia, 72(9-10), 781-797. doi: 10.1365/s10337-010-1721-8.

Bader, D., \& Agarwal, V. (2007). FFTC: Fastest Fourier Transform for the IBM Cell Broadband Engine. In S. Aluru, M. Parashar, R. Badrinath, \& V. Prasanna (Eds.), High Performance Computing - HiPC 2007 (Vol. 4873, pp. 172-184). Springer Berlin / Heidelberg. Retrieved from http://dx.doi.org/10.1007/978-3-54077220-0_19.

Bogdan, I., Coca, D., \& Rivers, J. (2007). Hardware acceleration of processing of mass spectrometric data for proteomics. Bioinformatics. Retrieved August 16, 2011, from http://bioinformatics.oxfordjournals.org/content/23/6/724.short.

Boyer, R. S., \& Moore, J. S. (1977). A fast string searching algorithm. Communications of the ACM, 20(10), 762-772. ACM. Retrieved August 7, 2011, from http://portal.acm.org/citation.cfm?id=359859.

Cameron, R. D. (2008). XML on Cell BE The Parabix Approach. Carleton University Cell BE Programming Workshop. Ottawa, ON.

Cameron, R. D., Herdy, K. S., \& Lin, D. (2008). High performance XML parsing using parallel bit stream technology. Proceedings of the 2008 conference of the center for advanced studies on collaborative research meeting of minds - CASCON '08, 222. New York, New York, USA: ACM Press. doi: 10.1145/1463788.1463811. 
Chen, T., Raghavan, R., Dale, J. N., \& Iwata, E. (2007). Cell Broadband Engine Architecture and its first implementation-A performance view. IBM Journal of Research and Development, 51(5), 559-572. doi: 10.1147/rd.515.0559.

Conrads, T. P., Anderson, G a, Veenstra, T. D., Pasa-Tolić, L, \& Smith, R D. (2000). Utility of accurate mass tags for proteome-wide protein identification. Analytical chemistry, 72(14), 3349-54. Retrieved from http://www.ncbi.nlm.nih.gov/pubmed/10939410.

Deutsch, E. W., Lam, H., \& Aebersold, R. (2008). Data analysis and bioinformatics tools for tandem mass spectrometry in proteomics. Physiological genomics, 33(1), 18-25. doi: 10.1152/physiolgenomics.00298.2007.

Eisenberg, D., Schwarz, E., Komaromy, M., \& Wall, R. (1984). Analysis of membrane and surface protein sequences with the hydrophobic moment plot. Journal of molecular biology, 179(1), 125-42. Retrieved from http://www.ncbı.nlm.nih.gov/pubmed/6502707.

Ferreira, A., Oliveira, A., \& Figueiredo, M. (2009). On the use of suffix arrays for memory-efficient Lempel-Ziv data compression. 2009 Data Compression Conference (p. 444). IEEE. Retrieved August 7, 2011, from http://www.computer.org/portal/web/csdl/doi/10.1109/DCC.2009.50.

Frank, A., \& Pevzner, P. (2005). PepNovo: de novo peptide sequencing via probabilistic network modeling. Analytical chemistry, 77(4), 964-73. Retrieved from http://www.ncbi.nlm.nih.gov/pubmed/15858974.

Johnson, R. S., Davis, M. T., Taylor, J. A., \& Patterson, S. D. (2005). Informatics for protein identification by mass spectrometry. Methods (San Diego, Calif.), 35(3), 223-36. doi: 10.1016/j.ymeth.2004.08.014.

Johnson, R. S., \& Taylor, J. A. (2002). Searching Sequence Databases via De Novo Peptide Sequencing by Tandem Mass Spectrometry. Molecular Biotechnology, 22(3), 301-316. doi: 10.1385/MB:22:3:301.

Kapp, E. a, Schütz, F., Connolly, L. M., Chakel, J. a, Meza, J. E., Miller, C. a, et al. (2005). An evaluation, comparison, and accurate benchmarking of several publicly available MS/MS search algorithms: sensitivity and specificity analysis. Proteomics, 5(13), 3475-90. doi: 10.1002/pmic.200500126.

Karp, R. M., \& Rabin, M. O. (1987). Efficient randomized pattern-matching algorithms. IBM Journal of Research and Development, 31(2), 249-260. IBM. Retrieved August 7, 2011, from http://ieeexplore.ieee.org/xpls/abs_all.jsp?arnumber $=5390135$.

Kiefer, J. (1953). Sequential minimax search for a maximum. Proc. Amer. Math. Soc, 4(3), 502. doi: $10.2307 / 2032161$.

Kim, Y. J., Feild, B., Fitzhugh, W., Heidbrink, J. L., Duff, J. W., Heil, J., et al. (2009). Reference map for liquid chromatography-mass spectrometry-based 
quantitative proteomics. Analytical biochemistry, 393(2), 155-62. Elsevier Inc. doi: $10.1016 /$ j.ab.2009.06.015.

Klammer, A. A., Yi, X., Maccoss, M. J., \& Noble, W. S. (2007). Using Peptide Retention Time Prediction across Diverse Chromatography Conditions, 79(16), 6111-6118.

Kohlbacher, O., Reinert, K., Gröpl, C., Lange, E., Pfeifer, N., Schulz-Trieglaff, O., et al. (2007). TOPP--the OpenMS proteomics pipeline. Bioinformatics (Oxford, England), 23(2), e191-7. doi: 10.1093/bioinformatics/btl299.

Kouzinopoulos, C. S., \& Margaritis, K. G. (2009). String Matching on a Multicore GPU Using CUDA. 2009 13th Panhellenic Conference on Informatics, 14-18. Ieee. doi: 10.1109/PCI.2009.47.

Krokhin, O. V. (2006). Sequence-specific retention calculator. Algorithm for peptide retention prediction in ion-pair RP-HPLC: application to 300- and 100-A pore size $\mathrm{C} 18$ sorbents. Analytical chemistry, 78(22), 7785-95. doi: $10.1021 / \mathrm{ac} 060777 \mathrm{w}$.

Ma, B., \& Lajoie, G. (2009). De novo interpretation of tandem mass spectra. Current protocols in bioinformatics, Chapter 13, Unit 13.10. doi: 10.1002/0471250953.bi1310s25.

May, D., Liu, Y., Law, W., Fitzgibbon, M., Wang, H., Hanash, S., et al. (2008). Peptide Sequence Confidence in Accurate Mass and Time Analysis and Its Use in Complex Proteomics Experiments. Journal of proteome research, 5148-5156. doi: $10.1021 /$ pr8004502.

Michalski, A., Cox, J., \& Mann, M. (2011). More than 100,000 detectable peptide species elute in single shotgun proteomics runs but the majority is inaccessible to data-dependent LC-MS/MS. Journal of proteome research, 10(4), 1785-93. American Chemical Society. doi: 10.1021/pr101060v.

Moruz, L., Tomazela, D., \& Ka, L. (2010). Training , Selection , and Robust Calibration of Retention Time Models for Targeted Proteomics research articles. Journal of Proteome Research, 5209-5216.

Mueller, L. N., Brusniak, M.-Y., Mani, D. R., \& Aebersold, R. (2008). An assessment of software solutions for the analysis of mass spectrometry based quantitative proteomics data. Journal of proteome research, 7(1), 51-61. doi: 10.1021/pr700758r.

Nesvizhskii, A. I., \& Aebersold, R. (2004). Analysis, statistical validation and dissemination of large-scale proteomics datasets generated by tandem MS. Drug discovery today, 9(4), 173-81. doi: 10.1016/S1359-6446(03)02978-7.

Nesvizhskii, A. I., Vitek, O., \& Aebersold, R. (2007). Analysis and validation of proteomic data generated by tandem mass spectrometry. Nature Methods, 4(10), 787-797. doi: 10.1038/NMETH1088. 
Norbeck, A. D., Monroe, M. E., Adkins, J. N., Anderson, K. K., Daly, D. S., \& Smith, Richard D. (2005). The utility of accurate mass and LC elution time information in the analysis of complex proteomes. Journal of the American Society for Mass Spectrometry, 16(8), 1239-49. doi: 10.1016/j.jasms.2005.05.009.

Peace, R. J., Mahmoud, H. A., \& Green, J. R. (2011). Exact String Matching for MS/MS Protein Identification Using the Cell Broadband Engine. Journal of Medical and Biological Engineering, 31(2), 99-104. Journal of Medical and Biological Engineering. doi: 10.5405/jmbe.824.

Petrini, F., Fossum, G., Fernandez, J., Varbanescu, A. L., Kistler, M., \& Perrone, M. (2007). Multicore Surprises: Lessons Learned from Optimizing Sweep3D on the Cell Broadband Engine. 2007 IEEE International Parallel and Distributed Processing Symposium (pp. 1-10). IEEE. doi: 10.1109/IPDPS.2007.370252.

Petritis, K., Kangas, L. J., Ferguson, P. L., Anderson, Gordon a, Pasa-Tolić, Ljiljana, Lipton, M. S., et al. (2003). Use of artificial neural networks for the accurate prediction of peptide liquid chromatography elution times in proteome analyses. Analytical chemistry, 75(5), 1039-48. Retrieved from http://www.ncbi.nlm.nih.gov/pubmed/12641221.

Petritis, K., Kangas, L. J., Yan, B., Monroe, M. E., Strittmatter, E. F., Qian, W.-J., et al. (2006). Improved peptide elution time prediction for reversed-phase liquid chromatography-MS by incorporating peptide sequence information. Analytical chemistry, 78(14), 5026-39. doi: 10.1021/ac060143p.

Pfeifer, N., Leinenbach, A., Huber, C. G., \& Kohlbacher, O. (2007). Statistical learning of peptide retention behavior in chromatographic separations: a new kernel-based approach for computational proteomics. BMC bioinformatics, 8 , 468. doi: $10.1186 / 1471-2105-8-468$.

Put, R., Daszykowski, M., Baczek, T., \& Vander Heyden, Y. (2006). Retention prediction of peptides based on uninformative variable elimination by partial least squares. Journal of proteome research, 5(7), 1618-25. doi: 10.1021/pr0600430.

Riedmiller, M. (1994). Rprop - Description and Implementation Details. Neural Networks, (January).

Sadygov, R. G., Cociorva, D., \& Iii, J. R. Y. (2004). Large-scale database searching using tandem mass spectra : Looking up the answer in the back of the book. Nature Methods, 1(3), 195-202. doi: 10.1038/NMETH725.

Scarpazza, D. P., \& Russell, G. F. (2009). High-performance regular expression scanning on the Cell/B.E. processor. Proceedings of the 23rd international conference on Conference on Supercomputing - ICS '09, 14. New York, New York, USA: ACM Press. doi: 10.1145/1542275.1542284.

Scarpazza, D. P., Villa, O., \& Petrini, F. (2007). Peak-Performance DFA-based String Matching on the Cell Processor. 2007 IEEE International Parallel and Distributed Processing Symposium, 1-8. Ieee. doi: 10.1109/IPDPS.2007.370634. 
Scarpazza, D. P., Villa, O., \& Petrini, F. (2008a). Exact multi-pattern string matching on the cell/b.e. processor. Proceedings of the 2008 conference on Computing frontiers - CF '08, 33. New York, New York, USA: ACM Press. doi: $10.1145 / 1366230.1366237$.

Scarpazza, D. P., Villa, O., \& Petrini, F. (2008b). High-speed string searching against large dictionaries on the Cell/B.E. Processor. 2008 IEEE International Symposium on Parallel and Distributed Processing, 1-12. Ieee. doi: 10.1109/IPDPS.2008.4536300.

Schatz, M. C., \& Trapnell, C. (2007). Fast Exact String Matching on the GPU. Retrieved from www.cbcb.umd.edu/software/cmatch/Cmatch.pdf.

Scherl, A., Francois, P., Converset, V., Bento, M., Burgess, J. a, Sanchez, J.-C., et al. (2004). Nonredundant mass spectrometry: a strategy to integrate mass spectrometry acquisition and analysis. Proteomics, 4(4), 917-27. doi: 10.1002/pmic.200300673.

Seidler, J., Zinn, N., Boehm, M. E., \& Lehmann, W. D. (2010). De novo sequencing of peptides by MS/MS. Proteomics, 10(4), 634-49. doi: 10.1002/pmic.200900459.

Shinoda, K., Sugimoto, M., Yachie, N., Sugiyama, N., Masuda, T., Robert, M., et al. (2006). Prediction of liquid chromatographic retention times of peptides generated by protease digestion of the Escherichia coli proteome using artificial neural networks. Journal of proteome research, 5(12), 3312-7. doi: $10.1021 /$ pr0602038.

Sturm, M., Bertsch, A., Gröpl, C., Hildebrandt, A., Hussong, R., Lange, E., et al. (2008). OpenMS - an open-source software framework for mass spectrometry. BMC bioinformatics, 9, 163. doi: 10.1186/1471-2105-9-163.

Sturm, M., \& Kohlbacher, O. (2009). TOPPView: an open-source viewer for mass spectrometry data. Journal of proteome research, 8(7), 3760-3. doi: $10.1021 / \mathrm{pr} 900171 \mathrm{~m}$.

Vasiliadis, G., Antonatos, S., Polychronakis, M., Markatos, E., \& Ioannidis, S. (2008). Gnort: High performance network intrusion detection using graphics processors. Recent Advances in Intrusion Detection (p. 116-134). Springer. Retrieved August 16, 2011, from http://www.springerlink.com/index/g2w54q11130r7126.pdf.

Vasiliadis, G., Polychronakis, M., Antonatos, S., Markatos, E., \& Ioannidis, Sotiris. (2009). Regular expression matching on graphics hardware for intrusion detection. Recent Advances in Intrusion Detection (p. 265-283). Springer. Retrieved August 16, 2011, from http://www.springerlink.com/index/b3m7662014272t8m.pdf.

Venter, J. C., Adams, M. D., Myers, E. W., Li, P. W., Mural, R. J., Sutton, G. G., et al. (2001). The sequence of the human genome. Science (New York, N.Y.), 291(5507), 1304-51. doi: 10.1126/science.1058040. 
Zerck, A., Nordhoff, E., Resemann, A., Mirgorodskaya, E., Suckau, D., Reinert, K., et al. (2009). An Iterative Strategy for Precursor Ion Selection for LC-MS / MS Based Shotgun Proteomics research articles. Journal of Proteome Research, 3239-3251.

Zhang, J., McQuillan, I., \& Wu, F. X. (2011). Parallelizing Peptide-Spectrum scoring using modern graphics processing units. ICCABS '11 Proceedings of the 2011 IEEE 1st International Conference on Computational Advances in Bio and Medical Sciences, 208-213. IEEE. Retrieved August 7, 2011, from http://www.computer.org/portal/web/csdl/doi/10.1109/ICCABS.2011.5729882.

Zimmer, J. S. D., Monroe, M. E., Qian, W.-J., \& Smith, Richard D. (2006). Advances in proteomics data analysis and display using an accurate mass and time tag approach. Mass spectrometry reviews, 25(3), 450-82. doi: 10.1002/mas.20071. 